\title{
La estética de la naturaleza en Fray Luis de León
}

\author{
NATURALEZA, LITERATURA E IDEAS
}

Presentar el problema de la literatura y las ideas en relación con el tema de la naturaleza es traer a discusión la posibilidad misma de la obra literaria para transmitir un pensamiento filosófico. Esto, que a primera vista no entraña dificultad alguna, es uno de los caballos de Troya de la moderna crítica literaria. Se niega al hecho literario la contextura reticular y organizada de los sistemas conceptuales, y se niega a las ideas la posibilidad de belleza. Ambas posiciones, por extremas y exclusivas, son parciales. Hemos de justificar la posibilidad de una literatura que se asienta sobre un pensamiento filosófico y de unos conceptos, propios o patrimoniales del momento histórico, que se expresan en términos de belleza al toque mágico del escritor o del poeta. Porque el tema de la naturaleza, a finales del siglo XV y durante todo el Renacimiento, tuvo derivaciones que atañen a las más diversas ramas del saber humano."

La confusión de límites entre las creaciones del pensamiento y de la literatura proviene, a nuestro modo de ver, de una cuestión de método más que de fondo. El estructuralismo, al hacer énfasis en la contextura misma de la obra literaria, ha minusvalorado otros determinantes que aclaran y potencian el fenómeno literario. La biografía del escritor, su contorno moral e intelectual, la historia precedente y su voluntad de comunicación, son elementos que el crítico ha de considerar para desentrañar todas las potencialidades de la creación artística. Según el estructuralismo, lo único que hay que analizar es la arquitectura del hecho literario y su significación. Esta actitud ha enriquecido, en gran manera, nuestra visión de la creación artística; pero, a su vez, como todas las posiciones polares, tiene fallos de omisión. Venía a ser una reacción a la crítica que concebía las obras literarias en función de las ideas que expresaban. Es cierto que, hasta finales del siglo pasado, la historia de la literatura era la historia de las ideas que el hombre había expresado a través de la forma literaria. Se tomó el lenguaje como vehículo de ideas, olvidando que él mismo es la más alta y bella de las creaciones del espíritu humano. Después, al aplicar 
los métodos de Saussure a la crítica literaria, se estudió, casi exclusivamente, el significante, olvidando que la forma exterior e interior se potencian mutuamente. A esta discusión en el campo general de la literatura se ha unido otra en la parcela de la poesía. Lo específico de la poesía, se dice, no es comunicar pensamientos, sino lanzar emociones con las que ha de simpatizar el lector. No existen las ideas poéticas, dice Housman; cuando más, lo que ocurre es que ciertas ideas conllevan la posibilidad de una expresión poética y otras no. Esas ideas reciben la transformación del poeta de tal forma que las glorifica. Ya no podrán verse separados ambos elementos, a no ser por el análisis. «Poesía no es lo que se dice, sino la forma de decirlo» '. Jean-Paul Sartre ha visto también el fondo del problema: «No se es escritor por haber decidido decir ciertas cosas, sino por haber decidido decirlas de cierta manera» ${ }^{2}$.

Esta concepción de la literatura que nosotros, por otra parte, subscribimos, ha puesto en entredicho, como un tabú, el estudio del sistema de pensamiento sobre el que toda gran creación se asienta. Nosotros hemos de estudiar en este trabajo muchas de esas ideas subyacentes que, por sí mismas, han llevado al escritor a su transformación en belleza. Es necesaria una justificación de esta actitud. En este capítulo queremos espigar varios acercamientos que los críticos han tenido en torno al tema de la naturaleza, ciñéndonos al Renacimiento. Algunos de ellos han escrito alguna página sobre Fray Luis. Queremos mostrar que no es posible dar una visión completa del tema si parcelamos la realidad literaria. Sólo un estudio comprehensivo que albergue el fenómeno literario, como tal, y la estructura conceptual que lo sostiene, puede darnos toda la riqueza de matices que se encierra en esta actitud, fascinada y profunda, que el poeta-pensador de Salamanca tiene ante la naturaleza.

René Wellek y Austin Warren, en su conocido libro «Theory of Literature», afirman la posición estructuralista en el estudio de la literatura; pero, al mismo tiempo, admiten el estudio de las ideas como soporte y potenciación de la literatura. Comentando la literatura inglesa nos recuerdan cómo Spencer escribió cuatro himnos describiendo el ascensus platónico desde la materia a las moradas celestes. Destacamos esta cita porque Spencer es uno de los poetas ingleses que, en alguna ocasión, ha sido puesto en relación con Fray Luis ${ }^{3}$. Respecto al sentimiento de la naturaleza, leemos:

«Algunas veces lo ideológico se interfiere con lo puramente emocional. En su actitud frente a la naturaleza, el hombie se encuentra profundamente influido, no sólo por especulaciones cosmológicas y religiosas, sino tambiện, directamente, por consideraciones estéticas, convenciones literarias y, posiblemente, incluso por cambios fisiológicos en su forma de ver» ${ }^{4}$.

1. A. E. Housman, The name and nature of poetry, Cambridge 1938, págs. 36 y 37.

2. J.-P. SARTRE, ¿Qué es la literatura?, Buenos Aires 1957, pág. 56.

3. A. BELL, Four poets of the Renaissance, Misc. en honra de Michaëlis de Vasconcelos, págs. 1-22.

4. René WAllek - AuStin Warrem. Theory of Literature, New York 1956, pág. 116. (Hay traducción en Ed. Gredos). 
Wellek y Warren reconocen aquí una penetración íntima entre lo emocional -específico de la poesía- y lo ideológico. Estas influencias que anotan son, cabalmente, un resumen de las que advertimos en Fray Luis. De todas ellas participa el genio poético. Estos autores incluso admiten cambios fisiológicos en la forma de ver. Sin llegar a esto, hemos de reconocer en la intuición luisiana de la naturaleza una proyección de la contextura psíquica personal. En el pórtico de Los Nombres de Cristo confiesa Marcelo que el paisaje despierta en él sentimientos de melancolía. Esta enfermedad, de moda en el Renacimiento, tenía en Fray Luis una base real. En el pedimento que hace el 31 de marzo de 1572, estando preso en las cárceles de la Inquisición de Valladolid, suplica que avisen a la monja Ana de Espinosa para que le envíe unos polvos para sus pasiones y melancolías de corazón ${ }^{5}$. La emoción, tan cálida y transformadora, que despierta la naturaleza en la oda a Juan de Grial tiene mucho que ver con la situación del poeta encarcelado o próximo a la prisión. Lo mismo podemos decir de esas preferencias por las tormentas del mar que vemos, especialmente, en el Comentario al Libro de Job. En el sentimiento de la noche estrellada ha de tener su parte el carácter del poeta. Él nos dirá de las muchas noches que ha pasado de diálogo con las estrellas. Debían de ser horribles aquellas noches en que Fray Luis tenía que dejar la celda conventual para bajar al patio y mirar las estrellas. Al hacer el Comentario al Libro de Job, Fray Luis se encariña con el personaje, y se proyecta en él. Por eso sabe muy bien que «las enfermedades de humor melancólico, cual éste era, toman fuerza con las tinieblas, que son la hora propia cuando la melancolía hierve y humea» ${ }^{6}$. Nuestro trabajo viene a mostrar que las más variadas actitudes o perspectivas concluyen el el tema luisiano de la naturaleza.

E. Gilson ha estudiado a Rabelais y Pascal bajo la perspectiva filosófica y ha escrito un libro planteando el mismo problema ? . Arthur O. Lovejoy, desde la revista «Journal of the History of Ideas», que agrupó a conocidos filósofos y lingüistas, defiende una posición opuesta: la literatura ha de estudiarse dando primacía a las ideas. Esta actitud es también extrema y parcial. La realidad literaria quedaría manca tanto si prescindimos del estudio del fenómeno en sí como si prescindimos de la red de ideas y de la tradición cultural en la que la creación está inmersa, por estarlo el creador.

Como antes indicaba, pensamos que la confusión es más de método que de fondo. Es claro que el tema de la naturaleza en Los Nombres de Cristo, por ejemplo, no puede ser estudiado de la misma forma que en la poesía o en las otras obras en prosa. En Los Nombres hay un paisaje concreto que es motiva-

5. Miguel Salvá y Pedro Sánz de Baranda, Colección de documentos inéditos para la historia de España, Madrid 1847, V. X. pág. 179.

6. FRAY LUIS DE LEÓN, Obras completas castellanas, Madrid 1959, pág. 909. Edición a cargo del P. Félix García. (Ed.ción válida para todo el trabajo en la que se refiere a las obras en prosa de Fray Luis de León).

7. E. Gilson, Les Idées et les Lettres, Paris 1932. 
dor y parte integrante, en gran manera, de la composición de la obra. Hay observación y arquitectura y emoción de la naturaleza. En las poesías hay también emoción, pero la localización es mucho menor, y la composición es más producto de la intuición que de un programa, como lo es en Los Nombres. Aparte la hondura filosófica que el tema adquiere en la obra poética. El tono es diferente. Por otra parte, hay en la naturaleza de Los Nombres de Cristo otras muchas perspectivas que sólo pueden verse si las aislamos del texto literario para ponerlas en relación con las demás obras de Fray Luis y con las corrientes espirituales del momento. El renacimiento fue un hecho tan complejo que reducirlo a este aspecto o al otro es minimizarlo. Si a esto unimos las corrientes filosóficas y científicas, la bíblica, la hebraica y la cristiana que confluyen en Fray Luis, nos daremos cuenta de que se impone tratar el tema tanto desde una perspectiva literaria como desde un sistema de ideas.

La visión religiosa, ética, pastoril, armónica, unitaria, del universo, está dentro de la situación espiritual que el escritor vivía. Lo que nos importa destacar es qué matices singularizadores toma en él. Con esto, al mismo tiempo que arar una parcelita de la historia de las ideas, habremos contribuido un poco a definir el estilo de Fray Luis. Y que a la belleza literaria hay que buscarle el lecho de un arroyo filosófico lo demuestran las consideraciones, breves pero significativas, que el escritor hace en sus obras latinas. En el comentario latino al salmo XXVI vemos claramente la conexión íntima que se da en el pensamiento luisiano entre la felicidad y el conocimiento del mundo exterior:

«Nam his duabus rebus continetur absoluta et cumulata beatitudo: Dei comtemplatione, scilicet, qua ex contemplatione oriuntur innumeras voluptates, et cognitione templi Dei, id autem est, universi hujus, quod unum est templum augustissimum atque maximum ${ }^{8}$.

La armonía del universo y la fascinación ante el cosmos son otros de sus sentimientos estéticos más destacados ${ }^{9}$. La naturaleza, vestida del sentimiento religioso de la huella de Dios, aparece en el comentario latino al Cantar de los Cantares y en el panegírico a san Agustín ${ }^{10}$. Otras veces es el contraste dolorido y el desengaño de una satisfacción imposible lo que arranca al poeta acentos de destierro y nostalgia por un mundo de verdad " ${ }^{11}$. Las obras latinas nos muestran un racimo apretado de pensamientos y sentimientos estéticos en torno a la naturaleza que justifican, en el sistema de ideas, muchas páginas de hellísima prosa castellana. Las obras latinas nos muestran al escritor en cuan-

8. Mag. Luysil Legionensis, Agustiniani Divinorum Librorum primi apud Salmanticenses interpretis Opera, nuc primum ex Mss. ejusdem omnibus PP. Agustiniensium studio edita. Salmanticae, MDCCCXCI, pág. 368, t. VII (Edición válida para les citas de las obras latinas en todo el trabajo).

9. Opera, VII, págs. 368 y $373-374$

10. Opera, II, pág. 50 y VII, 368-369.

11. Ib., I. 160 . 
to teólogo y filósofo, y nos atestiguan la apoyatura idelógica que el tema de la naturaleza tiene en Fray Luis.

Varios autores españoles han escrito algunas páginas sobre la significación de este tema en la literatura y el pensamiento del Siglo de Oro. Destacaremos a aquellos que, de una manera u otra, se han acercado a Fray Luis.

Ortega y Gasset se ciñe a la perspectiva ética que el tema de la naturaleza entraña. El retorno a la naturaleza, que es una de las características del Renacimiento, lo interpreta como una "vuelta atrás». El hombre acude al campo, cansado de tanta cultura, para encontrarse a sí mismo, es decir, para encontrar una cultura auténtica, la suya propia ${ }^{12}$.

A nuestro parecer, esta actitud de cansancio es la misma que obliga a Fray Luis a desear el retiro al campo. A esta cultura absorbente y falsa, por exterior, de que nos habla Ortega, se opone en el sistema de Fray Luis una naturaleza símbolo de la inocencia y la verdad, como veremos en su momento. Lo que también está claro en nuestro poeta-pensador es la huida al campo - un tanto idealizada, desde luego - como medio para encontrarse a sí mismo. Es algo que detectamos inmediatamente en Fray Luis. «Vivir quiero conmigo», nos dice en la oda "A la Vida Retirada»; en «Descanso después de la tempestad» el poeta huye «el trabajar perdido - la falsa paz»; y en la oda «Esperanzas burladas» el poeta aconseja al lector que se retire al campo: «Allí, contento, tus moradas sean; - allí te lograrás».

La idea que aquí aparece en Fray Luis es la vieja máxima socrática, pasada por el cedazo de los estoicos y la exaltación de san Agustín: la verdad habita en el interior del hombre. Es lo mismo de Fray Luis: «Porque cierto es que el verdadero pasto del hombre está dentro del mismo hombre, y en los bienes de que es señor cada uno" ${ }^{13}$. Con esto viene a afirmar también que la felicidad consiste en la posesión de bienes interiores, conforme a la división que hacía el estoicismo. La relación entre este sistema de ideas y la estética luisiana de la naturaleza consiste en que esa realización del hombre sólo se da en una huida al campo, que unas veces es de tono idealizante, pero otras es real y regocijado retiro a la finca de la Flecha. No es simple azar el que Fray Luis haya situado la narración de Los Nombres de Cristo a las orillas del Tormes. Para

12. «El hombre se ha distanciado y separado de sí merced a la cultura: ésta se interpone entre el verdadero mundo y su verdadera persona. No tiene, pues, mäs remedio que arremeter contra esa cultura, sacudírsela, desnudarse de ella, retirarse de ella, para ponerse de nuevo ante el universo en carne viva, y volver a vivir de verdad. De aquí esos períodos de «vuelta a la naturaleza», es decir, a lo autóctono en el hombre, frente y contra lo cultivado o culto en él. Por ejemplo, el Renacimiento; por ejemplo, Rousseau y el romanticismo y... toda nuestra época». 80.

José Ortega y GASSET, En torno a Galileo, Obras completas, Madrid 1947, t. V, págs. 79-

13. FRAY LUIS, Obras, Op. cit., pág. 455. Pastor. 
él, Cristo, bien supremo del alma, sólo se halla en el interior del hombre, y el hombre sólo realiza su interioridad en la vida de la naturaleza.

Américo Castro ha sabido penetrar en la problemática filosófica que el tema de la naturaleza trae al Renacimiento. Ha puesto el acento en el carácter de inmanencia que le llega del siglo $\mathrm{XV}$, y en la veta de misticismo religioso que se remonta hasta san Francisco de Asís. La valoración de la naturaleza como un poder inmanente proviene de Nicolás de Cusa. Con ellos se pone uno de los mojones más definitivos para la ruptura de la idea teocentrista del universo. Ya el occanismo había enunciado que el hombre no puede llegar por sí mismo a la fe; que la naturaleza del hombre es algo cerrado e incomunicable. Con ello se presta un gran servicio a la Reforma: ni nuestra razón ni nuestra voluntad pueden llevarnos a Dios. La Reforma niega el teocentrismo del universo de la tradición escolástica. No hay «vestigia Dei» en el mundo. No hay síntesis de lo natural y lo divino, del mundo sensible con un principio ${ }^{14}$.

La posición de Fray Luis será absolutamente contraria. Incluso su inspiración religiosa se hace poesía, y acerca la naturaleza a Dios. Sin embargo, a veces, da la impresión de que el escritor participa, inconscientemente, de esta ruptura que se operaba entre el universo y Dios. Así se explicaría el desgarrón afectivo de que habla Dámaso Alonso. Por un lado, el universo es la huella de Dios, conforme a la filosofía platónica y la inspiración cristiana; por otro, el mundo es lugar de dolor, y los movimientos de los astros apresuran al hombre a la muerte ${ }^{15}$. No hay aquí sólo la nostalgia de un ascensus hacia lo divino, sino la experiencia existencial de un mundo que ha sido dotado por el pensamiento renacentista de un ser inmanente y autosuficiente. Fray Luis, profundamente cristiano y profundamente histórico, debe de sentir la escisión en su propia carne. En cualquier caso, el hecho es que, frente a una religación teocentrista medieval, encontramos en Fray Luis una religación cristocéntrica. A su tiempo veremos lo que esto puede significar.

Indica el P. Félix García que Fray Luis sostiene aquí la misma teoría teológica que otros grandes pensadores como Escoto, san Alberto Magno, Suárez, san Agustín. A nosotros lo que nos interesa destacar es, primero: la complejidad del pensamiento luisiano sobre la naturaleza, en el que hay imbricadas ideas filosóficas, teológicas y literarias; segundo: cómo esta posición cristocentrista debe de ser la reacción inmediata a la ruptura entre Dios y el mundo que Fray Luis, en su ortodoxia intachable, resuelve a favor de una unión de distinto orden, y cuya significación no es ajena a la situación espiritual del pensamiento renacentista sobre la naturaleza y el universo todo. $\mathrm{Ni}$ teocentrismo ni inmanentismo, sino cristocentrismo. Es más, con frecuencia se cambia la perspectiva, y es Cristo quien pasea por los campos floridos, mi-

14. V.: Emile Brehiere, Historia de la Filosofía, Buenos Aires 1948, T. I, págs. 664 y ss.

15. Fray Luis, Opera, I, 295, In Ecclesiastem. 
tad metáfora, mitad realidad. Con ello, quedan afirmadas a un mismo tiempo la personalidad diferente del mundo y Dios, y su comunicación por medio de Cristo. De aquí ha de provenir ese tono, tan humano e íntimo, que se respira al contacto con la naturaleza luisiana. En ella todo y todos hablan. La naturaleza está en un diálogo permanente con el poeta. El sentimiento religioso ha colaborado a dar cercanía y calor al mundo natural, lo mismo que el pensamiento filosófico le da hondura y valor universal. La poesía, la filosofía y el sentimiento religioso han colaborado para ofrecernos la más elevada, bella y compleja creación del sentimiento de la naturaleza en el Siglo de Oro español. A nosotros, una devoción ferviente a la obra de Fray Luis y un entusiasmo parejo por la literatura española y la historia de las ideas nos mueve a analizar la significación del tema dentro de la creación del Renacimiento.

Sin embargo, Fray Luis participa, en otros aspectos, de un activismo de la naturaleza que acerca su pensamiento a la problemática renacentista. El mundo no es algo estático para él. La naturaleza participa activamente en el desarrollo del hombre. Viene a ser una colaboradora de Cristo en el perfeccionamiento del individuo. Es curioso observar cómo los verbos que expresan predicados de la naturaleza son, en su gran mayoría, de carácter activo: «El aire se serena - y viste de hermosura y luz no usada»; la fontana de La Flecha se apresura corriendo desde la cumbre airosa; « $\mathrm{El}$ aire al huerto orea - y ofrece mil olores al sentido»; el cielo hurta al hombre las horas del vivir y aoja con luz triste el ameno verdor otoñal. En Los Nombres de Cristo, al final del libro I, vemos al sol ponerse de puntillas para escuchar la conversación de los tres frailes y, después, al terminar el Nombre «Brazo de Dios», al caer la tarde, vemos que aparece un auditorio nuevo, el de la luna y las estrellas. Podríamos aducir otros muchos ejemplos. Esta forma de concebir la naturaleza proviene de aquella intimidad activa que el siglo XV había visto en la naturaleza. $\mathrm{Su}$ expresión más clara la tenemos en castellano en La Celestina, donde hay un panteísmo velado que es patente en otros autores del siglo XV. Américo Castro nos hace notar que, ya en la primera mitad del siglo XV, Lorenzo Valla dirá: «Idem est natura quod Deus, aut fere idem» ${ }^{16}$.

Debió de ser grande el drama intelectual de Fray Luis. Por una parte, había recibido de la Edad Media la idea de que el hombre era el centro de todas las cosas y que la naturaleza, completamente pasiva, estaba a su servicio. El sentido religioso franciscano hace ver la naturaleza exterior como una prolongación de los sentimientos de la persona humana; junto a esta idea, el neoplatonismo trae dos direcciones a la concepción del mundo natural: por una parte, se exalta al mundo como la huella de Dios; por otra, el mundo es motivo de contradicción y dolor ya que, si es huella, no es la auténtica realidad, y es una continua tendencia al no ser. En esta filosofía hay ya una de las raíces

16. Lorenzo Valla, De voluptate, I, 13. Citado por A. Castro en «El pensamiento de Cervantes», Madrid 1925, pág. 158, nota 3. 
que ha de llevar al desengaño del barroco. En el Comentario al Libro de Job la vida es para Fray Luis «muerte que cada momento hace vigilia a la muerte» ${ }^{17}$. Las cosas forcejean por volver a su nada ${ }^{18}$. En el mismo Comentario afirma que Dios es el señor de la naturaleza ${ }^{19}$. En el nombre «Faces de Dios» se respira el más puro franciscanismo cuando el poeta dice que Cristo «tiene cuenta con los pajarillos, y provee a las hormigas, y pinta las flores y desciende hasta lo más bajo del centro y hasta los más viles gusanos» ${ }^{20}$. La contradicción entre unas ideas y otras es clara. Se debe, desde luego, a una perspectiva diferente, pero lo que observamos, al fin, es la complejidad del sistema conceptual y la problemática de Fray Luis. Difícilmente se armonizan esas afirmaciones con otras que tienen un sabor a naturaleza como algo independiente, como «mayordoma de Dios»: «¿Cómo pudieran creer que la naturaleza, madre diligente y proveedora de todo lo que toca al bien de lo que produce, había de formar al hombre por una parte tan mal inclinado, y por otra tan flaco y desarmado para resistir y vencer a su perversa inclinación?» ${ }^{21}$.

Para el pensamiento medieval el hombre ocupaba el centro del universo; para el renacentista ese punto se ha desplazado a la naturaleza exterior. La teología cristiana había colaborado a la visión medieval: el hombre y su salvación era lo único que contaba. Así ocurre que el mundo se define en categorías metafísicas de substancia, esencia, materia, forma, cualidad y cantidad, en lugar de las físicas de espacio, masa y energía cuya evolución comenzará con el Renacimiento. El hombre imponía su forma de pensar a las cosas. Ha habido siempre, en el conocimiento de la naturaleza, dos perspectivas capitales: la observación directa y la imposición a priori de nuestras categorías mentales. Pitágoras, Aristóteles, Aristarco de Samos, están entre los que observan el mundo con ojos de físicos. Platón y gran parte de la Antigüedad, hasta los árabes, imponen al mundo sus principios mentales. En realidad ambas formas de pensar sobre el universo prevalecen hasta nuestros días. Las ciencias físicas, al tomar el número como la base de toda especulación cosmológica, han enjaezado al Pegaso del universo con los arreos de la mente.

San Agustín, gran observador y gran amante de la naturaleza, propone una actitud ecléctica: se ceñirá a la consideración estética, de raíz neoplatónica, de las categorías de armonía y unidad. Por lo demás, piensa que el conocimiento de la auténtica realidad del universo es imposible y, en ese caso, cada uno puede imaginárselo como mejor convenga para su propia salvación.

La Edad Media es una época de esquemas impuestos. Las cosas eran substancias diferentes, y no se comprendía cómo el agua podía pasar a hielo;

17. Fray Luis, Obras, pág. 906, Job 7,5.

18. Ib., pág. 762 , Jesús.

19. Ib. pág. 878 , Job 5,10 .

20. Ib. pág. 432, Faces de Dios.

21. Fray LuIS, Obras, 513, Dedicatoria del Libro II de Los Nombres. 
lo pesado y lo ligero eran distintas cualidades; la región de lo pesado está en la tierra y a ella tenderán las cosas pesadas; la región de lo ligero está en las alturas, y a ellas tenderán las cosas ligeras. El universo entero era un pequeño lugar donde el hombre tenía su reino. La Divina Comedia es el más claro ejemplo de esta concepción, esencialmente humana, del universo. La actitud contraria la encontramos en algunos autores modernos para quienes el hombre es el producto de la casualidad entre las infinitas posibilidades del cosmos ${ }^{22}$.

La ruptura entre el hombre y el cosmos comienza con el Renacimiento. Copérnico vuelve a estudiar la Antigüedad clásica y a aplicar métodos de observación. Kepler, partiendo de la revolución copernicana y de unos principios de estética neoplatónica, terminará, definitivamente, con la primacía del hombre sobre la naturaleza y el cosmos. Fray Luis participa de las ideas medievales de servidumbre y de la nueva actitud espiritual del Renacimiento que veía al mundo exterior como algo independiente. La riqueza de perspectivas es amplísima. Así, pues, la personificación de la naturaleza que hace Fray Luis tiene una ráiz medieval al interpretarla en términos humanos, pero el activismo que observa en ella es ya algo completamente renacentista. Este sentido agresivo, cambiante e inesperado produce en el poeta un desasosiego radical.

Para completar estas ideas de fondo, es necesario recordar que las formas literarias clásicas llegan al Renacimiento a través de los humanistas. Por ello, a una posición espiritual se une una estética humanista que idealizará la naturaleza y expresará su inocencia en las aspiraciones a una Edad de Oro y el retorno a las formas virgilianas de lo pastoril. La Antigüedad clásica presta la forma y el acento al pensamiento renacentista. De ese gusto por lo espontáneo y primario parten las encendidas alabanzas a los refranes y a la lengua vulgar. Cuando Fray Luis hace el panegírico de la lengua castellana, tiene a sus espaldas toda la forma de mirar que partió, en su origen, de un cambio de perspectiva en la forma de mirar el universo. Bajo esta concepción bucólica de la naturaleza hay algo que ni soñó la Antigüedad clásica: el drama del hombre que ha dotado a la naturaleza de un poder propio y de un activismo humano y que, sin embargo, se enfrenta ante ella como ante el enigma de la Esfinge. Dentro de la influencia de una filosofía platónica Fray Luis suspirará, transido de nostalgia y esperanza, por el conocimiento esencial del auténtico ser de las cosas. Aquí la oda, tan fecunda, que dirige a su amigo Felipe Ruiz «¿Cuándo será que pueda...?». Como dice Housman, la inspiración del autor será la varita mágica que transforme y glorifique estaș ideas. Pero tratar de estudiar el hecho literario sin atender a este sistema mental es minimizar la misma creación artística, y al revés. Esto es lo que tratamos de demostrar al exponer el problema del movimiento del universo. Es curioso observar cómo fueron

22. V.: E.A. BURTT, The metaphysical foundations of modern physical science, London 1967, págs. 1 y ss. 
las corrientes del pensamiento que afluyen en torno a la naturaleza en el Renacimiento y que, de una manera u otra, participan en la creación luisiana. Más adelante hemos de desarrollar estos temas detenidamente.

Isaza Calderón, en un libro riguroso, ya citado, sigue la huella de su maestro A. Castro en la forma de concebir el tema. El autor indica que su primer propósito fue investigar sobre el tema de la alabanza de aldea, pero que, a falta de un estudio general sobre la materia, se decidió a prepararlo él mismo. Su interés se centra en la significación ideológica y vital de ese retorno desde los albores de la literatura castellana hasta los umbrales del Renacimiento ${ }^{23}$.

Menéndez Pelayo da la mano a las ideas y a la literatura. Son conocidas sus páginas de fervor hacia el poeta de Belmonte. Él abrió múltiples caminos para tratar a Fray Luis: la filosofía, la literatura, el misticismo, la situación del contorno espiritual e intelectual. Su simpatía por el pensamiento platónico llega hasta los más secretos conductos de la veta poética luisiana. En las páginas de Menéndez Pelayo el cosmos luisiano canta el ascensus platónico y su deseo de una esencialidad que Laín Entralgo recogió en un artículo de un libro suyo ${ }^{24}$.

El P. Ángel C. Vega hace énfasis en la corriente mística que supone una de las posiciones que hemos esbozado. Este ilustre editor de las poesías de Fray Luis viene a incidir en una de las corrientes fundamentales en el pensamiento sobre la naturaleza: la que ve el universo como objeto de nuestra contemplación ${ }^{25}$. A. Castro resume las dos posiciones:

«En resolución, se vería que la idea de la naturaleza, balbuceada por el pobrecillo de Asís sale de la Edad Media en dos direcciones convergentes: el mundo vale por reflejar a Dios y llevar a Él, y el mundo es como Dios y hay que atemperarse a sus exigencias. El drama moral y religioso en el siglo XVI girará en torno a esas dos formidables posiciones» ${ }^{26}$.

Con el P. Vega hay otros autores que interpretan la obra de Fray Luis dentro de una marcada corriente mística y, por ello, su sentimiento de la naturaleza también. Aquí podemos citar a Oreste Macrí y Rousselot. Dámaso Alonso interpreta a Fray Luis como un desterrado. A nosotros no nos pertenece entrar en un tema tan debatido. Baste remitirnos a los críticos reconocidos que se han acercado a ello. Se advierte, sin embargo, que las peculiares condiciones de cada uno suelen influir en la perspectiva crítica. Nosotros mismos no podemos escapar a esta ley del hombre. Conforme analicemos las obras del poeta salmantino, habremos de espigar las distintas actitudes que en cada momento se nos ofrecen. El arte de la lectura es difícil; por ello es el pri-

23. Baltasar Isaza Calderón, op. cit., Madrid 1934.

24. Pedro laín Entral.go, La aventura de leer, Madrid 1956.

25. Ángel C. Vega, Poesía de Fray Luis de León, edición crítica, Madrid 1955.

26. A. Castro, El pensamiento de Cervantes, Madrid 1925, pág. 176, nota 3. 
mero que trata de enseñar la moderna crítica estructuralista. Para quien desea gustar la complejidad de la idea y la melodía del lenguaje el estudio de Fray Luis es un sendero de primera mano. A medida que leemos su obra y vamos uniendo retazos alejados en las páginas del libro o nos detenemos en este o aquel remanso dejándonos llevar por la agilidad de la idea pronta, comprendemos la riqueza de pensamiento y la estructura literaria, tan definida, en que se halla enmarcado el tema del presente trabajo.

E. Orozco ${ }^{27}$ y A. Valbuena Prat ${ }^{28}$ han dedicado algunas páginas sentidas y bellas al sentimiento de la naturaleza en Fray Luis de León. Con ellos hay que citar al P. Félix García que ha sabido llegar de lleno al tema en alguna de sus perspectivas. Las cuatro o cinco páginas que dedica a esta materia en la introducción de Los Nombres de Cristo de su edición de la BAC son definitivas.

El estudio de la significación de la naturaleza en la obra de Fray Luis de León ofrece múltiples perspectivas. Cuando tratamos de investigar las raíces del sentimiento de la naturaleza en un escritor estamos alumbrando su actitud emotiva frente al mundo natural. Pero el hombre no sólo reacciona emotivamente frente al exterior. Es claro, desde luego, que ello supone una atención singular a lo que nos rodea. Una reacción emotiva sólo se produce después que hemos dirigido nuestra mirada inquisidora hacia el objeto. Ocurre, además, que el sentimiento de la naturaleza se ciñe a la simpatía del escritor con un cuadro enmarcado. Así se limita al paisaje con fronteras espaciales, visuales o valorativas. El sentimiento de la naturaleza hay que entenderlo como la vivencia de nuestra propia vida en relación con el mundo natural que nos rodea, es decir, la experiencia personal ante el paisaje que es «la completa unidad estética que el mundo físico circundante ofrece a la contemplación visual» ${ }^{29}$. En Fray Luis encontramos esta vivencia del paisaje, de una forma especial, en Los Nombres de Cristo. Hay, además, otra vivencia de la naturaleza sin marco. En el Comentario al Cantar de los Cantares hay detalladas descripciones de la vida y costumbres de los animales. Algunas están inspiradas en Plinio y Dioscórides, pero otras tienen el sabor inconfundible de la experiencia directa. Algo semejante ocurre en La perfecta casada. En el Comentario al Libro de Job es la vivencia de una naturaleza teñida por la visión dolorida del escritor. En las poesías vemos el tema en toda su trascendencia y hondura filosóficas. El sentimiento de la naturaleza es sólo una parte de la complejidad que el tema adquiere dentro de la obra luisiana. Hay en toda ella un aliento de sentimiento cósmico alimentado por una visión filosófica, ética 1968.

27. Emilo Orozco, Paisaje y sentimiento de la naturaleza en la poesía española, Madrid

28. Ángel Valbuena Prat, Historia de la literatura española, Barcelona 1963.

29. José M. a SÁnChez de MUNiAIN, Estética del paisaje natural, Madrid 1945, pág. 127. 
y metafísica, más indefinible que el de la naturaleza, pero más profundo, que se cuelga, como la hiedra a todas las manifestaciones de su arte.

La naturaleza, por primera vez en la literatura castellana, entra a formar parte integrante de la composición literaria. Aquí hemos de analizar y desentrañar la significación literaria que el tema tiene en Fray Luis y que se centra en Los Nombres de Cristo. Por no haberlo estudiado dentro de la composición de la obra, se les ha escapado a los autores la auténtica función del paisaje luisiano. No bastan unas cuantas consideraciones sobre el sentimiento de la naturaleza en el poeta de Salamanca. La maravilla es muy grande. Al estudio literario hay que añadir que Fray Luis es un pensador de primera magnitud que se halla en la encrucijada de dos actitudes, la medieval y la renacentista. El Renacimiento le trajo una forma nueva, más aguda, de mirar el mundo exterior. El escritor tiene su propio sistema de ideas éticas, filosóficas y estéticas sobre la realidad del mundo y sobre las relaciones que se dan entre el hombre y su contorno. Todo ello sobrevolado siempre por la inspiración privilegiada del poeta. Margot Arce de Vázquez ha visto claramente la trascendencia que tiene la vinculación del hecho literario a la historia, la cultura, el pensamiento y la sociedad de una época. En su libro sobre Garcilaso estudia lo poético en relación con las manifestaciones espirituales que brotan del Renacimiento, y llega a ver la poesía de Garcilaso, la política de Carlos V y la Casa de las Conchas de Salamanca dentro de un mismo sentido histórico ${ }^{30}$. Esta es también nuestra actitud en gran parte de este trabajo. Aunque en ocasiones estudiaremos la literatura como tal, nuestra preocupación constante es mostrar en el tema de la naturaleza en Fray Luis el pensamiento y la estética renacentistas. Por este camino llegaremos, al final, a una conclusión ya conocida: que Fray Luis es uno de los más ilustres representantes del Renacimiento y que su musa es una de las más ricas cajas de resonancia de la España del Siglo de Oro.

No podemos dejar de lado la biografía de Fray Luis. Es necesario acudir con mucho cuidado a la vida de un autor. A este respecto podemos considerar dos direcciones fundamentales: la del biógrafo, que estudia en las obras de un personaje su etopeya, y la del crítico, que estudia la vida para alumbrar conclusiones sobre la obra. Esta segunda"actitud es la que nos interesa aquí: sólo admitimos el estudio de la biografía para resolver caminos dudosos en el análisis crítico. Por ello, sólo en contadas ocasiones acudiremos a la vida de nuestro escritor. Claro está que hay aspectos artísticos y biográficos que se iluminan mutuamente. Cuando penetramos en el carácter agresivo de Fray Luis, en su auténtico deporte por las oposiciones a la Universidad, en su formidable destreza para dejar en ridículo a un contrincante, en su afán de la verdad a cualquier precio, comprendemos mejor el fondo de cansancio y desencanto

30. Margot Arce de Vázquez, Garcilaso de la Vega, Puerto Rico 1969, pág. 9. 
que vemos en la oda A la Vida Retirada. La melancolía negra de su carácter —en lucha con su agresividad- nos explica mejor su sentimiento de la noche estrellada. Muchas horas nocturnas debió de pasarse Fray Luis asomado a la ventana y contemplando el firmamento de la noche limpia de Salamanca. Puede que debamos a aquella angustia que le ahogaba el corazón algunas de las más bellas poesías de la lengua castellana. El paisaje de La Flecha es algo que vive en el poeta junto a esa contemplación del misterio cósmico. Nada de idealización. La Flecha es un trozo de naturaleza real que nada tiene que ver con el mundo paisajístico de la novela pastoril o de los libros de caballerías. Es una parcela de geografía que se ha colado en las páginas de un libro, y que nos ha descubierto el paisaje literario. Es sabido que La Flecha era la granja de recreo que tenían los agustinos a las orillas del Tormes, a donde se retiraban en las vacaciones y días de asueto. Después de muchos años de abandono, a principios de este siglo, fue vuelta a su primitiva figura. Paisaje plácido, al estilo clásico, pero totalmente real. Paisaje, literatura, ideas y biografía entrelazados en Los Nombres de Cristo ${ }^{31}$.

El P. Saturnino Álvarez Turienzo es uno de los críticos que mejor ha visto la actitud vital de Fray Luis. Para él, Fray Luis ni es un escéptico ni es un místico. Siempre está de este lado. Su humanismo estaba hecho para cantar lo divino en la natural y humano. Sentirá un profundo respeto por las palabras, por los nombres. Para entender a Fray Luis importa el recuerdo de la situación espiritual que le rodea. El poeta organiza su obra en torno a un concepto personal de sabiduría. Para él, la creación es un escrito, y su conocimiento una lectura o una traducción. El Logos sembró su palabra en la naturaleza, y el destino de las cosas es acercarse a Dios ${ }^{32}$. Recordemos de pasada la relación de esta idea con la tradición medieval del Libro de Cosmos y con la formulación que, años más tarde, hará Galileo:

«La Filosofía está escrita en ese gran libro que está siempre ante nuestros ojos - quiero decir el universo-, pero no podemos comprenderlo si antes no aprendemos el lenguaje y el significado de los símbolos en que está escrito. Este libro está escrito en el lenguaje matemático,..." ${ }^{33}$.

Poesía y naturaleza eran el refugio espiritual de Fray Luis. Dámaso Alonso contempla al poeta evadiéndose a la torre aislante del pensamiento filosófico y de la poesía: «Filosofía y poesía y naturaleza, bello reflejo de la divina se-

31. «Es un paisaje modesto, casi pobre, sencillísimo, lírico a la vez, sin exuberancias ni esplendideces deslumbradoras, con aire purísimo y extensión vasta, con ámbito transparente. $\mathrm{Pa}$ rece la tierra un nuevo soporte del cielo; es el paisaje en que mejor se comprende que se fusionaran en el alma del Maestro León, el humanitarismo y la mística, Horacio y el Aeropagita». (MIguel de Unamuno, Paisajes, Madrid 1950, pág. 25.

32. Saturnino Álvarez Turienzo, Sobre Fray Luis de León filólogo, La ciudad de Dios 169 (1956), págs. 112-136.

33. GallLeo, Opere complete di Galileo Galilei, Firenze 1842, ff., IV, pág. 171. Cita de E. A. Burtt, op. cit., pág. 64 . 
renidad» ${ }^{34}$. La misma idea expresa el Prof. Muñoz Alonso: «En el estilo de Miró acontece algo semejante -y tengo afición a ejemplificar con este nombre - a lo que le ocurre a Fray Luis de León. Su creación es el único medio de que dispone para equilibrar su alma» ${ }^{35}$.

Víctor de Laprade, uno de los más finos representantes de la sensibilidad en torno a la naturaleza, como poeta y como crítico, ha calado en la esencia misma de este sentimiento. Plantea el problema de la relación entre el artista, la naturaleza y la creación literaria. Ideas, naturaleza y literatura se hermanan en lo más hondo del poeta. Éste ha de aprender a conocerse a sí mismo para comprender la naturaleza, que pasará de ser una música interior a ser un pensamiento:

«La verdadera poesía de la naturaleza parte, como toda poesía, del corazón del hombre y nunca de los objetos que le rodean; procede de un sentimiento que hay que expresar y nunca de una serie de imágenes que hay que reproducir; no hace del paisaje una escena luminosa, animada y comunicativa sino dándole un corazón humano que haya de dialogar con la naturaleza, y de tomar a la naturaleza misma como la voz de un alma que hable al hombre, como la voz de lo invisible, de lo ideal, de lo infinito, es decir, de Dios» ${ }^{36}$.

Este sentido de diálogo es permanente en la obra de Fray Luis. Ya lo hemos indicado más arriba. El poeta siente el ala del misterio rozando su cara cada vez que las cosas quedan en silencio, y el sol, las estrellas y el paisaje departen amistosamente con él. Es en Los Nombres de Cristo donde percibimos mejor este temblor del poeta. El sentimiento de un diálogo con la naturaleza ese algo que debemos tener presente en todo momento al leer a Fray Luis. Ya Garcilaso y Herrera y Aldana se habían acercado a la naturaleza con mimo; pero se trataba todavía de algo idealizado. Para Fray Luis de Granada el mundo exterior tendrá ya las más íntimas resonancias, pero sin superar la fina emoción que le lleva a una traducción de tipo religioso. Fray Luis de León -iqué grandes los dos Luises! - se comunica con una naturaleza real, a la que ha prestado humanidad la poesía. Pocas veces se detiene en la descripción de un mundo natural. Solameñte en el Comentario al Cantar de los Cantares encontramos algunas decripciones detallistas y llenas de sentimiento. En lo demás, es la preocupación metafísica, la sugestión de un paisaje o de un momento, la magia de un vocablo feliz lo que hará entrar por nuestras ventanas un raudal de naturaleza. Este detalle mínimo, aquella alusión certera, dejarán en nosotros una huella perdurable. Así sabemos de su comunicación continua con la naturaleza, de su recuerdo del otoño desde la próxima cárcel inquisitorial, de su afición a la jardinería (él ha debido de plantar un pequeño huerto en

34. Dámaso Alonso, Poesía española, Madrid 1962, págs. 169-170.

35. Adolfo Muñoz Alonso, Los presupuestos filosóficos del estilo de Gabriel Miró, Revista de Ideas Estéticas, 1957, XV, pág. 132.

36. Victor de Laprade, Le sentiment de la nature chez les modernes, Paris 1870. nág. 219. 
La Flecha), de sus escarceos por el campo de la astrología, de sus largos ratos de observador de la fauna y la flora. Sabemos que el poeta ha prestado su corazón a los animales, a los campos, al firmamento «El artista que no conoce el alma (dice Laprade), no conoce la naturaleza. Porque la naturaleza es algo diferente de aquello que se ve o se toca, algo diferente, en una palabra, de la materia; y no tendrá su parcela de poesía más que teniendo su parcela de vida y alma, y esto, sólo Dios y el corazón humano se lo pueden dar» ${ }^{37}$. Y, sobre todo, sabemos de su mirada, larga y profunda, preguntándose por el verdadero ser de las cosas del mundo. Una curva de pensamiento que se abre con un deseo ético de retiro al campo y a la soledad, que se continúa con una unión sentimental y mística con el mundo y que se cierra con una esperanza platónica de conocer la verdad del universo y una interpretación simbólico-religiosa: los dos brazos de la Y del pensamiento luisiano sobre el mundo exterior.

Resumiendo: nuestro propósito en este trabajo es desentrañar el tema de la naturaleza, en su sentido amplio que comprende el contorno vital y el universo entero, en la obra de Fray Luis de León, y ponerlo en relación con la filosofía y la estética del Renacimiento. En el sentimiento de la naturaleza hay un entramado de valores muy complejo. Porque las cosas sólo devienen maravilla cuando las tocan las manos del genio creador. Por tanto, es importante destacar la transformación que el escritor hace de su contorno. Esta transformación sólo se opera dentro de un estilo y un pensamiento que son los peculiares del artista. El poeta presta a la naturaleza y al cosmos su sensibilidad. El mundo exterior será un poco lo que sea el artista y su vida. Éste interpretará su contorno dentro de su propio esquema de ideas. Sobre todo ello está la inspiración poética. En definitiva, ese algo indefinible que llamamos poesía vinculará al poeta y a la naturaleza. Si la investigación literaria trata de alumbrar esa zona, siempre oscura, entre la creación, el artista y la naturaleza, que se resuelve en el campo de las emociones y la composición literaria, la investigación conceptual e histórica ha de mostrarnos la carga ideológica y vital que el escritor trae a su interpretación de la naturaleza. Bien dice Laprade que «le sentiment de la nature est dans notre âme une musique, avant de devenir une pensée» ${ }^{38}$. A la música corresponde aquí la investigación literaria; el pensamiento, la investigación de las ideas y el sistema cultural en que la creación artística tiene lugar. Se ha de investigar cómo toda la riqueza de posibilidades se hace vida en el escritor y se torna hacia la creación y la estética de la naturaleza. Consiste, en suma, en estudiar la forma exterior e interior de la obra. Dámaso Alosno nos ofrece claridad en la definición:

Forma exterior es «la relación entre significante y significado en la perspectiva desde el primero hacia el segundo».

37. V. LAPRADE, op. cit., pág. 325.

38. V. LAPRADE, op. cit., pág. 234. 
Forma interior es «esa misma relación, pero en la perspectiva del significado hacia el significante» ${ }^{39}$.

Los estudios desde la forma interior son más difíciles porque «se trata en ellos de ver cómo afectividad, pensamiento y voluntad creadores, se polarizan hacia un moldeamiento, igual que materia, aún amorfa, que busca su molde` ${ }^{40}$. El estudio de la forma exterior e interior -en esta última es nuestro acento- en la obra de Fray Luis de León, que hemos centrado en el tema de la naturaleza, ha de darnos la función y la significación de este tema dentro de la estructura y el sistema luisiano de ideas.

39. D. Alonso, Poesía española, Madrid 1962, págs. 32-33.

40. Ibid. 


\section{PRIMERA PARTE}

\section{LAS OBRAS EN PROSA}

\section{LA NATURALEZA PRESENTIDA DE LA «EXPOSICIÓN DEL CANTAR DE LOS CANTARES»}

Ya hemos indicado anteriormente que los métodos de estudio del tema de la naturaleza en Fray Luis de León serán diferentes para cada parte de su obra, y ello porque es diferente también la inspiración y la finalidad de que se parte. Es imposible intentar abarcar el quehacer creador luisiano desde un solo punto de vista, tanto si se trata de la forma interior como si si trata de la exterior. En la Exposición del Cantar de los Cantares no encontramos tan definidas ni la trabazón estructural que se da en Los Nombres de Cristo, ni la indagación filosófica de las poesías, ni las preocupaciones éticas de La perfecta casada o del Comentario al Libro de Job, ni los sentimientos estéticos luisianos sobre la armonía del cosmos de algunos pasajes de Los Nombres. Pero sí es cierto que en el Cantar encontramos en ciernes todas esas formas de ver la naturaleza y algunas de ellas tienen aquí su mejor representación. Nuestro análisis pretende espigar las diversas perspectivas que el poeta nos ofrece ya al comienzo de su obra. Como en todo este trabajo, nos preocupa constantemente el poner en relación a Fray Luis con la estética renacentista ya que, como dice el P. Félix García, «Fray Luis de León es todo el Renacimiento español. Es su síntesis más acabada y exacta, pues acierta dichosamente a recoger todas las tendencias renovadoras e inquietas del Renacimiento... ' ${ }^{\prime}$. Intentaremos mostrar en qué manera la naturaleza es un motivo que arranca desde la misma vela literaria de armas de Fray Luis. El resto de su obra será un ahondamiento de estas primeras visiones naturalistas y un enriquecimiento de las posibilidades del tema.

Fray Luis comienza la Exposición del Cantar de los Cantares alrededor de los treinta y tres años, en plena juventud. Según nos dice en el prólogo, escribe la obra a instancias de Isabel Osorio, monja del convento de SanctiSpiritus de Salamanca, que no sabía latín. Para ayudar a nuestro poeta, Arias Montano le envía, desde su convento de San Marcos, la exposición del Cantar que él mismo tenía hecha desde 1554. Fray Diego de León, fámulo de Fray Luis, encuentra el manuscrito y copia la obra que, en principio, sólo fue escrita para el uso privado de Isabel Osorio. Las coplas se extienden rápidamente y, poco después, el Comentario era conocido incluso en América. Más

1. Fray Luis, Op. cit. 11. 
tarde será una fuerte prueba de cargo en el proceso inquisitorial. En 1580 Fray Luis publica una Triplex Explanatio del Cantar.

Sin duda alguna la explicación castellana del Cantar era un auténtico desafío intelectual para el poeta. Muchos otros habían intentado ya la exégesis con anterioridad. ¿Por qué escribir una obra que, de acuerdo con el Concilio de Trento y otros precedentes, iba contra las normas de la Iglesia? La solución hay que buscarla en la biografía luisiana y en las corrientes estéticas del Renacimiento. Indirectamente se nos descubren en esta obra los años juveniles del poeta, cọmo se descubrirían los años maduros en el Comentario del Libro de Job. Pensamos que el Cantar de los Cantares tuvo que ejercer una atracción fascinante sobre Fray Luis, no sólo por el reto intelectual que ello suponía, sino también porque rimaba con el carácter ardiente y juvenil del poeta y con una actitud estética del momento.

Si comparamos esta Exposición del Cantar con las demás obras en prosa, comprenderemos mejor la vivencia personal diferente de la que nació. Así, frente al cansancio y desengaño barrocos del Job, lo que hallamos en el Cantar es un apasionado deseo de vivir. Frente a un nacer en el Comentario al Job que es un empezar a morir, como en Quevedo, la expresión exultante de la vida del Cantar, donde el poeta bebe naturaleza a través de «La mañana, la luna y el sol, que son toda la alegría y regocijo y belleza del mundo» ${ }^{2}$. El tema del Cantar es el amor; el del Job es el más hondo y maduro del mal. Al gozo inmediato de la naturaleza en el Cantar corresponde un temblor secreto ante una naturaleza en su más dramática manifestación: las tormentas. Al lenguaje nervioso y castizo del Cantar suceden las densas consideraciones del Comentario al Job sobre la vida del hombre. En el Cantar la vida y la naturaleza aparecen más bellas de lo que son; en el Job, menos. Libro de vida y juventud es el Cantar; de dolor y madurez, el Job. La Exposición del Cantar resulta también de un tono muy diferente respecto a La perfecta casada. Una ética normativa preside las páginas de esta última obra; la ley del amor, que es la menos normativa, preside el Cantar. Los Nombres de Cristo representan el ápice de la creación luisiana en prosa. En estos diálogos los sentimientos estéticos tienen su lugar adecuado en la arquitectura de una composición bien pensada. La Exposición del Cantar, por su misma condición de Comentario, carece de esa plenitud estructural de Los Nombres de Cristo que revela una poderosa voluntad de estilo. Ahora bien, si el Comentario al Cantar carece de la profundidad del Job, de la proyección ética de La perfecta casada y de la construcción de Los Nombres, supera a todas estas obras en la frescura del estilo, en la espontaneidad del tratamiento y en la observación de las cosas de la naturaleza, características todas ellas de una estética de juventud. Añádase a ello, como hemos indicado, que en esta obra se encuentran en germen la ma-

2. Op. cit., 160. Cantar 6,9 . 
yor parte de las formas y sentimientos que despertará en Fray Luis el tema de la naturaleza.

También las corrientes estéticas del momento vienen a favorecer la Exposición del Cantar. Por los años de 1561-63 España está todavía bajo las ideas colectivas e imperiales que habían alimentado las décadas anteriores. Cuando se escribe el Comentario del Libro de Job, España comienza a declinar su poderío y el individualismo hispánico se apodera de los espíritus. El hombre ha de resolver su propio problema. Fray Luis escribe los últimos capítulos de la Exposición del Libro de Job después de la derróta de la Armada Invencible. Las actitudes espirituales y las estéticas son diferentes al escribir ambas obras. Es cierto que en 1554 aparece el Lazarillo de Tormes, una de las obras máximas del individualismo español, pero, como actitud vital, no tendrá vigencia hasta finales del siglo XVI y durante la primera mitad del XVII en que aparece el Guzmán de Alfarache. Cuando Fray Luis de León escribe su Comentario al Cantar de los Cantares lo que está en el ambiente es una estética idealizada y naturalista que proviene del género pastoril. Téngase en cuenta que la primera edición de la Diana, de Jorge de Montemayor, debió de aparecer en 1558 ó 1559. Como indica A. Valbuena Prat ${ }^{3}$, la naturaleza de la novela pastoril no es falsa, sino de tono intelectualizado, al estilo del gran Renacimiento o de los fondos de Rafael. El género pastoril, tanto novelístico como ecológico, trae la belleza del campo, a los espacios abiertos. Un sentimiento de ternura y de gozo íntimo invade los ambientes campestres, y un fino sensualismo está presente en las relaciones de hombres y mujeres. Hay una sutil idea de panteísmo en todo ello. Hay, además, la idea de una vuelta a lo espontáneo cuya significación estudiaremos más adelante. Curiosamente, mientras nuestro poeta es un duro detractor de los libros de caballerías y de los verșos y amoríos, él mismo va a recrear uno de los libros más sensuales de la literatura mundial. Siempre tendrá las más encendidas alabanzas para la vida pastorị.

Al terminar de radactar el Cantar es cuando la situación comienza a cambiar. En 1565 se puplica el Manual de Epicteto que ponía de manifiësto la preferencia por un neoestoicismo que los autores cristianos tratarán de santificar en las próximas décadas y cuya influencia se percibirá todavía un siglo más tarde. Este resurgir del estoicismo en la segunda mitad del siglo XVI había sido precedido en España por una corriente de pensamiento que ya se había destacado en el siglo XV con Alonso de Cartagena y los demás humanistas españoles. En la segunda mitad del siğlo XVI comienza a dar sus frutos esta filosofía. En Europa entera Justo Lipsio desplazará a Erasmo. Este neoestoicismo está presente en todas las páginas de la Exposición del Libro de Job. Frente a esta filosofía del desencanto priva el bucolismo idealista por los años

3. A. Valbuena Prat, Historia de la Literatura Española. Barcelona 1963, 1, 713. 
en que Fray Luis comenta el Cantar. En la visión serena e imperial de Virgilio frente a la descomposición que presencia Séneca. En el aire de los comentarios del Catedrático de Salamanca encontramos el aroma de la Églogas y las Geórgicas virgilianas que él mismo tradujo. La fascinación de Virgilio, lo pastoril y su defensa de la naturaleza frente al arte, la juventud del poeta: todo eso se respira en la Exposición del Cantar. Podemos decir que el Comentario del Cantar de los Cantares responde a una estética renacentista y el Comentario del Libro de Job a una estética barroca. En el equilibrio están los Nombres de Cristo. Pues bien, todo esto se refleja en el tema de la naturaleza. Podemos imaginar la riqueza y complejidad que entrañará.

\section{La perspectiva de la observación.}

La forma de tratar la naturaleza en esta obra es el primer momento de la trayectoria que el tema ha de seguir en Fray Luis de León. Aquí se marca ya la dirección. Al final del recorrido podremos reconocer estos motivos primeros. Todos los elementos que encontramos aquí permanecerán en las demás obras, aunque algo modificados.

Lo primero que advertimos es un finísimo espíritu de observación que rastrea las maravillas de la flora y la fauna del Cantar. Como en tantas otras invenciones del Renacimiento, Fray Luis descubre la naturaleza de la mano de los clásicos y sobre una obra clásica también. El Comentario del Cantar obliga al poeta a conocer la naturaleza. Para informarse, estudia especialmente a Plinio y Dioscórides. De ellos toma noticias, y algo más importante: el método de la observación realista. Algunos de los pasajes naturalistas están basados en los clásicos, pero muchos de ellos - los más encantadores- provienen de la observación asombrada del escritor. Es el mismo camino que los científicos del Renacimiento hallaron en los clásicos: para conocer el universo hay que volver a la observación directa. En la controversia entre aristotélicos y neoplatónicos, se toma el sistema aristotélico de observación, pero se niega su física del cosmos. Es el neoplatonismo quien da alas al método aristotélico. $\mathrm{Al}$ interesarse por las cosas de la naturaleza, Fray Luis da un gran paso respecto a los escritores precedentes. Garcilaso de la Vega deja entrar el paisaje en sus versos, pero todavía no se ha puesto a mirar de cerca la naturaleza. Herrera y Aldana observan ya mejor, y dejan aparecer sentimientos estéticos más íntimos, como el de la noche. El sentimiento luisiano de la naturaleza comienza por la observación directa y por la preocupación de un conocimiento fiel de las cosas. Y nadie que conozca las maravillas de la naturaleza puede escapar a su encanto. Aquí se unen dos grandes Luises: el de Granada y el de León. Fray Luis de León se ve obligado a salir de sí mismo para encontrar el mundo exterior. Éste es el acercamiento más auténtico que se halla en la raíz del sentimiento de la naturaleza. Así, las cosas que rodean al hombre ad- 
quieren personalidad y substantividad propias. La naturaleza, que había sido mirada en la Edad Media en función del hombre, encuentra ahora sus derechos. Se dice que el Renacimiento humaniza a la naturaleza. La diferencia entre la actitud medieval y la renacentista es de perspectiva: ver la naturaleza en función del hombre es despojar de su ser a las cosas del entorno a favor de nuestro interés personal, que en la Edad Media se traducía en una salvación religiosa; humanizar la naturaleza es justamente lo contrario; es el hombre quien se acerca a ella para prestarle sus sentimientos y para rendirle la veneración de su mirada. Pero esta actitud tiene su origen en una observación continuada y entusiasmada del mundo exterior. Observar y organizar es lema de la estética renacentista. Las cosas que rodean al hombre habían vuelto por sus fueros y exigían una mirada atenta a quien quisiera arrancarles su misterio.

Fray Luis captura a la naturaleza sus más finos detalles. Con ello, al mismo tiempo que recrea los motivos naturalistas del Cantar de los Cantares, conquista el mundo exterior para su saber y para su creación. Partirá desde esta base para las más elevadas consideraciones éticas y metafísicas sobre el universo. Si analizamos detenidamente las preferencias estéticas del momento, incluso podríamos pensar que el Cantar es la ocasión o exćusa que el poeta tiene para desahogar su propia sensibilidad juvenit, cercana a temas alejados de su espíritu religioso; porque para Fray Luis la Biblia es el único hontanar que merece la pena. En el prólogo nos dice que solamente ha trabajado en declarar la corteza de la letra. Si leemos atentamente la Exposición del Cantar, nos parecerá que en muchos pasajes ha contado más su personal predilección que una dificultad seria de comprensión.

La fauna y la flora se ha asomado a su mirada detallista. Comenta la metáfora «ojos de paloma» de la amada:

«Y porque una gran parte de la hermosura está en los ojos, que son el espejo del alma... dice que son como de paloma. Las que vemos por acá no los tienen muy hermosos, pero sonlo de hermosísimos las de la tierra de Palestina, que como se sabe por relación de mercaderes y por una que traen de Levante, que llaman tripolinas, son muy diferentes de las nuestras, señaladamente en los ojos, porque los tienen grandes y muy redondos, de resplandor y de un movimiento velocísimo y de un color extraño que parece fuego vivo»" ${ }^{4}$.

Obsérvese, de paso, cómo esta predilección por los ojos entra dentro de las preferencias renacentistas. Para nosotros fue Cetina quien trabó los ojos a la claridad del entendimiento en el primer verso del conocido madrigal «Ojos claros, serenos...». En el contexto ideológico responde esto a la idea de que la belleza auténtica está en el interior; los ojos son las ventanas y el espejo del alma, según la metáfora platónica que aquí trae Fray Luis. Otras veces serán «hermosos, matadores y alevosos» en el rostro de la mujer amada.

4. Op. cit. 85-86 Cantar 1,14 . 
Podríamos citar muchos detalles de esta fascinada observación del poeta. Fray Luis sabe también que el palomo y la paloma se guardan constante fidelidad una vez que se han emparejado; y ha visto los celos en los ojos del palomo inquieto; y que las palomas hacen su nido en los caseríos arruinados de los campos. Conforme al tipo de belleza femenina renacentista nos dice que «la bondad y gentileza de los dientes está en que sean debidamente menudos, blancos, iguales y bien juntos» ${ }^{5}$. Fray Luis ha visto a las raposas pequeñas entrar en una viña en agraz y hacer un gran daño, y la experiencia le ha traído la vista, de sabor virgiliano, de un rebaño de ovejas perdiéndose en la lejanía:

«Porque, como se ve, las ovejas vienen tan juntas en su manada, que a quien las mira algo apartado le parecen ser todas una cosa blanca como una sábana tendida, que no se paresce entre ellas más espacio que lo que hay de los pies de la una a los pies de la otra; porque por ser delgados los pies y los cuerpos gruesos, tócanse arriba con los lados del cuerpo y abajo llevan los pies una de otra apartados y así va aquello negro con las sombras que ellas hacen. Mas son llenas y han cada una parido dos, como aquí se dice, vienen los corderitos encajonados entre ellas, porque cada una lleva sus dos hijos a los lados, los cuales hinchen aquel vacío que los pies de ellas dejaban; y de este modo no queda entrada a la vista de quien las mira para penetrar en ellas, ni conocer que una esté apartada de otra, sino todo por abajo y por encima parece un cuerpo blanco y hermoso, como la experiencia lo demuestra» ${ }^{6}$.

Se advierte en este pasaje un gusto de Fray Luis por describir algo que él mismo ha visto: "porque, como se ve...», "como la experiencia lo muestra...» «Un pequeño detalle del Cantar le ha llevado a este sentido desahogo de sentimiento de la naturaleza. También los detalles de tipo psicológico sobre los efectos del amor o la pasión revela esta actitud contempladora del poeta. Fray Luis busca siempre una explicación basada en la observàción cotidiana y en lo que recoge del ambiente. Por eso sabe que en «tierras orientales y en todas las tierras calientes, tienen por más galano el cabello negro, como aun hasta hoy se precian de él los moros».

También la flora ha recibido su mirada atenta:

«Pues como suelen los claveles asomar por los agujeros pequeños de los encañados que los cercan o de las vainas que rompen cuando brotan, y como las rosas que cuando salen no se descubren todas sino solamente un poco, así imagina y dice que su Esposo... se descubre» ${ }^{8}$.

5. Op. cit. 120. Cantar 4,2 .

6. Op. cit. 121. Cantar 4,2 .

7. Op. cit. 146. Cantar 5,12.

8. Op. cit. 98. Cantar 2,9 . 


\section{Fidelidad a lo real}

El escritor persigue una fidelidad a la realidad que será actitud permanente en toda su obra. Nos dice que no explicará el sentido espiritual del Cantar por ser ya algo conocido. Y esto es cierto; pero, además, Fray Luis se halla encadenado por este respeto a lo que nos da la vista, que era el signo del pensamiento renacentista. Claro está que el neoplatonismo hacía énfasis en la doble realidad de las cosas: la aparente y ficticia, y la real y verdadera. Pero se ama lo aparente y fenoménico más que nunca porque es reflejo de lo ideal y porque es el único camino para conocer la verdad. Esta es la trayectoria del tema de la naturaleza en la obra luisiana: desde una devoción encendida a las cosas caminará en peregrinaje de vientos, mares y estrellas hacia lo ideal. El barroco está al final, cuando el hombre, ante la impotencia de conocer la auténtica realidad ideal, lamenta la única que tiene presente, la aparencial. El Renacimiento es un camino de marcha jubilosa, mientras que el barroco es un camino de vuelta. Es al fin y al cabo, la sístole y la diástole del acontecer del hombre en su historia.

Fray Luis, al atender a la expresión literal del Cantar, tributa un homenaje de adhesión a la situación espiritual en que vive. Más tarde, al explicarlo en latín, el poeta se encontrará más cerca de lo ideal. Es el momento para volver al sentido íntimo de las cosas. Por ello a la excusa de una reparación de su falta primera o de una promesa al amigo Arias Montano hay que añadir el momento personal del poeta ya dispuesto para alumbrar aguas más hondas. También el tono pastoril del Cantar le acerca a lo auténtico y primitivo del hombre. Recordamos que, según la Biblia, el oficio de los primeros hombres era el de labrador o pastor. Fidelidad a la realidad de la forma literaria del Cantar, que lo toma como una égloga pastoril 9 .

Cuando Fray Luis afirma que la traducción ha de ser cabal y respetuosa se encuentra también dentro de esta fidelidad de que hablamos. La vida entera del poeta fue una lucha contra la mentira y la hipocresía. Caballero de la verdad, nacido en un lugar de la Mancha, como Don Quijote, ya había velado sus armas en el sermón de Dueñas. Pasó la vida en un lance de honor contra la injusticia, la mentira y la estupidez. Muchos años más tarde, otro don Quijote de la pluma, como él, le recordará por los paisajes y el alto soto de torres de la ciudad de Salamanca. Los dos catedráticos de la Universidad salmantina, Fráy Luis y Miguel de Unamuno, tendrán mucho en común. Terminamos nuestra indagación por el elemento de la observación y la fidelidad a lo real con un párrafo de Carlos Vossler:

9. «Porque se ha de entender que este libro en su primer origen sé escribió en metro, y es todo él una égloga pastoril, donde con palabras y lenguajes de pastores hablan Salomón y su Esposa, y algunas veces sus compañeros, como si todos fuesen gente de aldea». Op. cit. 65. Prólogo Cantar. 
«Pero basta leer algunas páginas de los escritos en prosa de nuestro poeta como, por ejemplo, la descripción de un hombre que va a tientas en la oscuridad (Comentario de Job, XII, 25), para covencerse de la capacidad de observar y describir de una manera plástica lo más característico en cuerpos y movimientos» ${ }^{10}$.

\section{Sensualismo}

Otro elemento que le viene dado a Fray Luis por el mismo Cantar es el fino sensualismo con que se matiza toda la naturaleza. El tema fundamental de la obra es el amor. La más elegànte delicadeza vela las expresiones del Cantar, pero el escritor no niega nunca una aclaración, por fuerte que sea. Fray Luis encuentra traducido a lo divino todo un mundo amado de bucólica clásica en que la naturaleza era el marco adecuado para el amor. Por eso aclara que el Amigo «... convida en este lugar a la Esposa al gozo de sus amores; y porque él anda en el campo, que es el lugar para el amor mejor que otro, pídele que salga a él» ${ }^{11}$. Veremos más adelante que esta sensualidad, descargada de su sentido erótico, preside la concepción luisiana de la naturaleza. Claramente lo vemos en el sentimiento horaciano de «Vida retirada». El mismo paisaje de Los Nombres de Cristo se halla transido de sensualidad. Fray Luis encuentra santificada en el Cantar la naturaleza de Virgilio. En esta obra tenían cabida su viveza juvenil, su espíritu religioso y su quehacer de traductor de las Églogas y las Geórgicas. De aquí su total entrega a este comentario.

Junto a este sensualismo naturalista tenemos una idea neoplatónica y humanista: el amor mueve todas las cosas ${ }^{12}$; él es quien da unidad y armonía al universo. Tendremos ocasión de volver sobre este tema al tratar del sentimiento estético de la armonía y su significación dentro del Renacimiento. La raíz neoplátonica de esta idea se relaciona con la admiración constante que Fray Luis sintió hacia Petrarca. Téngase en cuenta que este erotismo estilizado se da en la primera etapa de Fray Luis, a la que se atribuye la redacción de sus cinco sonetos amorosos. Halla en el Cantar la forma de expresar a lo divino el sentimiento amoroso que tan bien supo expresar en los sonetos citados. En el capítulo V se refiere a Petrarca y en el II cita al poeta petrarquista catalán

10. Carlos Vossler, Fray Luis de León, Madrid 1960., pág. 98-99.

11. Op. cit. 98 . Cantar 2,13 .

12. La expresión más bella de este sentimiento la hizo Dante en los versos finales de la Divina Comedia:

A l'alta fantasia qui mancò possa;

ma già volgeva il mio disio e'l velle,

si come rota ch'igualmente è mossa,

l'Amor che move il sole e l'altre stelle. 
Ausías March en unos versos de tono melancólico que es el permanente en la naturaleza luisiana:

No vea mis escritos quien no es triste,

o quien no ha estado triste en tiempo alguno.

Son versos de la primera cantiga de Ausías March que traduce el mismo Fray Luis.

La metáfora del Cantar ayuda a nuestro escritor a velar el eros naturalista, pero él amplía la imagen a su placer. Nada le detiene, y parece que un secreto gozo aroma la frescura de sus comentarios. Fray Luis amplía a su aire la metáfora con que el amante requiebra a la amada: «Tus pechos, como dos cabritos mellizos, que están paciendo entre azucenas»:

«No se puede decir cosa más bella ni más a propósito que comparar los pechos hermosos de la esposa a dos cabritillos mellizos, los cuales, demás de la terneza que tienen por ser cabritos, y de la igualdad por ser mellizos, y demás de ser cosa linda y apacible, llena de regocijo y alegría, tienen consigo un no sé qué de travesura y buen donaire, con que roban y llevan tras sí los ojos de los que los miran, poniéndolos afición de llegarse a ellos y tratarlos entre las manos» ${ }^{13}$.

Hay un paisaje que nos permite ver que Fray Luis es consciente de la semejanza que se daba entre algunas formas del Cantar y las humanistas de Petrarca. Ello quiere decir que el poeta siente el Cantar como algo del momento en que vive. Nos confirma en nuestra idea de que el Cantar de los Cantares debió de llamar la atención de Fray Luis, no sólo por la petición de Isabel Osorio, sino también porque veía en él una estética actual. Trae siempre a sus comentarios y sus versos un vasto saber humanístico:

«Como aquel gran poeta toscano que, habiendo de loar los cabellos, los llama oro, a los labios grana, a los dientes perlas y a los ojos luces, lumbres o estrellas; el cual artificio se guarda en la Escritura Sagrada más que en otra del mundo" ${ }^{14}$.

Hemos dicho que Fray Luis no se arredra ante ninguna expresión naturalista del Cantar, por naturalista que sea. Sin embargo, hay una ocasión en que, entre bromas y veras, confiesa su asombro. Se trata del versillo 1 del capítulo 7: «El cerco de tus muslos como ajorcas hechas por mano de oficial». Aquí nuestro poeta tiene una de las salidas más espontáneas de toda su obra: «Desciende aquí a tantas particularidades el Espíritu Santo, que es cosa que espanta» ${ }^{15}$.

\footnotetext{
13. Op. cit. 124. Cantar 4,5 .

14. Op. cit. 148. Cantar 5,14.

15. Op. cit. 168. Cantar 7,1 .
} 


\section{El sentido platónico de la belleza}

Otro de los elementos estéticos de la naturaleza luisiana del Cantar, y que será capital en el resto de su producción, es el concepto platónico de la belleza. Es el signo de un Fray Luis peregrino por la hermosura de las cosas a la búsqueda de la realidad ideal y permanente. Este sentimiento de nostalgia de más ser se destaca mucho más en las poesías. Aquí está la raíz de lo que Dámaso Alonso entiende por la condición de desterrado de Fray Luis. La expresión más elevada de esta búsqueda la encontramos en los versos esencialistas de la oda a Felipe Ruiz «¿Cuándo será que pueda...?». Ya desde el principio de su creación plantea el problema del conocimiento en términos platónicos. Esta veta platónica de Fray Luis será permanente en sus obras, y le llevará a un sentido esencialista del cosmos $\mathrm{y}$, mediante la catarsis del desengaño, a lo religioso-místico y a Cristo donde se centra, en última instancia, la realidad cosmológica. Hemos de volver muchas veces sobre esta idea.

«... y porque la belleza está no solamente asentada en la exterior muestra de la buena proporción de facciones y escogida pintura de naturales colores, más bien, y principalmente, tiene su silla en el ánima, y porque esta parte de la hermosura del ánima se llama de gracia, y se muestra de fuera y se da a entender en los movimientos de la misma ánima, como son mirar, hablar, reír, cantar, andar y los demás, los cuales todos en lengua toscana generalmente se llaman atti, de manera que sin esta belleza la otra del cuerpo es una frialdad sin sal y sin gracia, y menos digna de ser amada que lo es una imagen, como cada día se ve..." ${ }^{16}$.

Este sentido íntimo y trascendente, platónico y petrarquista, será el que aflore cuando el poeta se ocupe de la belleza real del cosmos todo. Cuando el poeta llegue a la madurez intelectual, estos principios producirán en él un desgarrón continuo. Por una parte, sentirá la emoción de la maravilla del contorno exterior; por otra, su pensamiento platónico le llevará a un desengaño de lo aparente y a una interrogación angustiada por el ser verdadero de las cosas. Antes de arribar al gozo de la comprensión definitiva en lo místico-religioso, el camino platónico le proporcionará los más exultantes hallazgos y las más tristes decepciones, lo que viene a alimentar esa velada melancolía que penetra el mundo luisiano de la naturaleza y que se presenta como la nostalgia de más belleza y más ser.

\section{El sentimiento religioso-místico}

El misticismo religioso es el punto terminal de la peregrinación del poeta a través de la naturaleza y el misterio del cosmos. Esta trayectoria se ve clara-

16. Op. cit. 86. Cantar 1,15 . 
mente en las poesías donde toda la especulación filosófica y poética sobre el universo termina en una significación cristocéntrica. Así la oda «A la vida del cielo». Ya desde el Cantar vemos definido el camino que ensambla el plano filosófico platonizante al teológico. Aquí es donde los párrafos de Fray Luis y los versos de san Juan de la Cruz se dan la mano, quizás porque este último leyera al maestro, o quizás porque el poeta de Ávila también tomó la savia del Cantar de los Cantares. He aquí acentos del más puro misticismo en la relación que se da entre Dios, las criaturas y el ascensus religioso, en una de las pocas ocasiones en que Fray Luis intenta la explicación espiritual del Cantar:

«En todas partes está Dios, y todo lo bueno y hermoso que se nos ofrece a los ojos en el Cielo y en la tierra y en todas las demás criaturas, es un resplandor de su divinidad, y por secreto y oculto poder está presente en todas, y se comunica con todas. Mas estar Dios así es estar encerrado; y, lo que se ve de él, aunque por ser de él es bien perfecto, por parte de los medios por donde se ve, que son limitados y angostos, vese imperfectamente y ámase peligrosamente. Quiere, pues, la Esposa tenerle fuera, que es gozarle así sin miedo ni tercerias de nadie, y sin ir mendigando y como barruntando su belleza por las criaturas.... ${ }^{17}$.

\section{La comunicación}

Uno de los puntos de vista más importantes en el tema luisiano de la naturaleza es el de la comunicación. Es el sentimiento de la comunión que hay entre todo lo existente, y que procede de un sentimiento de unidad y armonía. Volveremos con frecuencia a este elemento. La naturaleza, el erotismo y la emoción del Cantar se prestan a este sentido de la comunicación entre las cosas. Es el más auténtico sentimiento de la naturaleza. El poeta le presta el alma que ella no tiene. Como hemos indicado, esto supone una revolución copernicana en la forma de mirar el mundo exterior. La emoción del pueblo hebreo, llena de naturalismo, favorecía esta comunicación. La poesía hebrea asocia la naturaleza a las manifestaciones de sus sentimientos personales. Como apunta Américo Castro, para el hebreo la naturaleza es un modo directo de llegar a Dios. Muchos de las símbolos de su religión tienen una inspiración naturalista. La vida se desarrolla al aire libre. Es el sentido de la tierra que perdura hasta los hebreos del moderno Estado de Israel. Los salmos son la expresión más patente de este sentimiento. Y con ellos el Cantar de los Cantares. Fray Luis siente la misma emoción. La naturaleza colabora con el hombre, se siente unida a él. Nuestro poeta ha penetrado en la esencia misma de la comunicación

17. Op. cit. 186. La semejanza con san Juan de la Cruz es clara. En otra ocasión Fray Luis explica el sintagma Enferma soy de amor conforme a lo que comúnmente se suela decir en nuestra lengua: «Decidle que perezco, que me fino de amor» (Op. cit. 143). El P. Félix García se pregunta en la nota 47: ¿Cómo no suponer que el santo leyó esta Exposición de Fr. Luis? 
de las cosas, y pone en ello mucho de su parte. Lo vemos en el comentario del capítulo 2:

«... y haciendo de todo una sentencia seguida, será como si dijese: «Levántate, amor mío, de ahí donde estás en tu cama acostada, y vente y no tengas temor a la salida, porque el tiempo está muy gracioso... La sazón es fresca, el campo está hermoso, todas las cosas fovorecen a tu venida y ayudan a nuestro amor, y parece que la naturaleza nos adereza y adorna el aposento».

Las últimas palabras son exclusivamente de Fray Luis, y son las que más nos interesan a nosotros. Porque, al principio del siglo XVI hubo otro autor, también de origen hebreo, que puso en los labios de una muchacha gentil y enamorada palabras del todo semejantes al comentario de Fray Luis. Se trata de la "Tragicomedia de Calixto y Melibea». La naturaleza de la Celestina nos ofrece algunos de los problemas capitales del Renacimiento. Sin duda alguna se adelanta a todos los escritores de la primera mitad del XVI en la fuerza y complejidad con que presenta su problemática, y hay que llegar precisamente a Fray Luis para encontrar la proyección de algunos de sus elementos. Y aquí, en el Cantar, es donde se encuentran más destacados.

La naturaleza de la Celestina se halla matizada de un tremendo erotismo apenas estilizado por el ambiente de estética neoplatónica en que se desarrolla la obra. Al consumar la fusión de Dios y la naturaleza se adelanta a los filósofos posteriores que, como Giordano Bruno, la única hipóstasis que admiten es la vida del universo. Un panteísmo naturalista está presente en la obra. Quizás sea la situación de un converso a quien le han sustituido su Dios por uno que no comprende, Cristo. En realidad sólo queda el segundo de los elementos que hacían la vida del hebreo, la naturaleza. Al desviar el misterio judaico desde su Dios a un Cristo que no comprende bien el hebreo, la naturaleza queda sustantivada. Al romper la mitad del puente no hay posibilidad de ir a Dios por la naturaleza, y ella se convierte en un Dios. A esto hay que añadir un neoplatonismo que deviene naturalismo al favorecer la idea de que sólo algunos elegidos pueden percibir el ser de Dios. Con ello se llega a divinizar lo terreno. En la base del sentimiento de la comunicación, tal como lo entienden muchos pensadores del Renacimiento, está la idea de un poder autóctono e inmanente en la naturaleza. De aquí el sentido de colaboración. Fray Luis y los místicos seguirán el otro camino que les brinda el pensamiento religioso: la búsqueda del significado del universo por un enraizamiento en el Dios de la teología. Pero en la Celestina encontramos ya ese intimismo del hombre con las cosas que sí está presente en la estética luisiana. Sus expresiones nos traen, a veces, el recuerdo de una naturaleza independiente, como en este caso, al despojarle a la palabra de su artículo.

En el acto XIX, uno de los más sensuales y dramáticos de la Celestina, Melibea hace cantar a Lucrecia, mientras ella espera, encendida, la llegada de Calixto. Las imágenes de los versos son todas naturalistas. Después hay un momento en que Melibea y Lucrecia cantan juntas. En un tono de cancioncilla 
popular ambas piden a los elementos de la naturaleza que hagan su homenaje a Calixto. Esto es mucho más que poner a los árboles por testigos, como hace el Cantar o Garcilaso. Esto entra ya en la estética del comentario de Fray Luis. Los versos que cantan son:
«Dulces arboles sombrosos humillaos, quando veays aquellos ojos graciosos del que tanto desseays. Estrelas que relumbrays norte y lucero del dia ¿por que no le despertays si duerme mi alegria?» ${ }^{18}$.

El deseo se comunica a los árboles umbrosos. Melibea presta su corazón a la naturaleza. Pero entonces llega Calixto que ha estado oculto, oyéndolo todo. Melibea, sorprendida, siente que las cosas se unen a ella para soportar tanta emoción. La infinitud lo llena todo:

Mel.- O sabrosa traycion! O dulce sobresalto! .... Todo se goza este huerto con tu venida. Mira la luna, quan clara se nos muestra; mira las nuues, como huyen; oye la corriente agua desta fontezica, quanto mas suave murmurio' y ruzio llena por entre las frescas yeruas. Escucha los altos copreses, como se dan paz vnos ramos con otros, por intercession de vn templadico viento que los menea. Mira sus quietas sombras, quan escuras estan, y aparejadas para encobrir nuestro deleyte» ${ }^{19}$.

Es el mismo sentimiento de cercanía de las cosas y el hombre que encontramos en Fray Luis de León. La escena del huerto de Melibea, llena de intimismo e identificación con la naturaleza, es un preclaro antecedente ${ }^{20}$. La idea proviene del temblor divino con que el hebreo ve la naturaleza, completamente alejada de la visión del clásico romano para quien el mundo se terminaba en el contexto social del hombre. En el espíritu del israelita el hombre se sentía prolongar en los campos que cultivaba, y en los que se manifestaba Dios. Nada de esto hay entre los latinos. Esta forma de comunicación supera en vigor y expresividad a la más cercana y bella forma latina, tal como la supo escribir Virgilio: Sunt lacrimae rerum. También el otro Fray Luis de ascendencia hebrea, el de Granada, supo acercarse como nadie a la naturaleza. Y es que

18. Tragicomedia de Calixto y Melibea, Libro támbién llamado de la Celestina, edición de M. Criado de Val y G. D. Protter, Madrid 1965, pág. 279.

19. Op. cit. 279-280, La perfecta casada, 8.

20. A propósito de este pasaje de la Celestina y el sentimiento de la naturaleza en Fray Luis dice acertadamente Garrido Pallardó: «En este mismo acto la identificación de los estados de ánimo con la naturaleza es una maravilla de adivinación sobre la que nada se ha dicho. Menester será reçificar algunas ideas a propósito de la adivinación de la naturaleza en el fraile poeta, pues ya estaba adivinada bastantes años hacía» (Fernando Garrido Pallardó, Los problemas de Calixto y Melibea y el conflicto de su amor, Figueras 1957, págs. 100-101). 
el conocimiento de Dios a través de sus creaciones es de origen bíblico, hebreo y platónico.

Resumiendo: Es claro que, ya desde el comienzo de su obra, la naturaleza se nos presenta en Fray Luis con una riqueza de formas y una complejidad de ideas sin par en la literatura y el pensamiento españoles del Renacimiento. La Exposición del Cantar de los Cantares supone un cruce de actitudes que ya estarán presentes en el resto de la creación luisiana. Este comentario, que era un desafío intelectual para el escritor, respondía a la situación estética renacentista, porque suponía la exaltación de lo pastoril, lo espontáneo y el amor. A ello hay que unir una juventud combativa.

El primer elemento que se destaca y que vincula a Fray Luis con la estética nueva, es la observación. El poeta llegará a sentir hondamente la naturaleza porque antes la ha observado con detalle. Ello significa una permanente fidelidad a lo real que se irá transformando en tema de dolor ya que, desde una posición platónica, la realidad auténtica es la ideal, y ésta es poco asequible.

Otro elemento que ya encontramos aquí es el fino sensualismo con que se arropa la naturaleza. Despojado del carácter erótico que tiene en esta obra, estará presente en los demás libros de Fray Luis. Una delicadeza petrarquista vela el encanto luisiano por la naturaleza.

Fray Luis tiene un sentido platónico de la belleza. Lo que importa es la gracia interior, de la que el porte exterior es reflejo. A ello hay que añadir lo que será el final de esta trayectoria: un misticismo religioso que ve las cosas de la naturaleza como reflejo de Dios y que supone una constante invitación al hombre para que peregrine en busca del ser auténtico.

La comunicación con la naturaleza y el universo es el último elemento que encontramos en nuestro análisis. Pertenece al más genuino sentimiento de la naturaleza. El hombre y el contorno se hallan unidos por la magia de la intuición que une y armoniza todo le existente. El sentido cosmológico hebreo, que tiene su primera manifestación hispánica de altura en la Celestina, preside el espíritu del comentario luisiano al Cantar de los Cantares. La Biblia, como fuente, y el platonismo como camino son las dos raíces de la estética de la naturaleza en Fray Luis de León.

\section{EL SENTIDO ÉTICO DE LA NATURALEZA EN «LA PERFECTA CASADA»}

Fray Luis escribió La perfecta casada después de la Exposición del Cantar de los Cantares, pero la obra no fue publicada hasta 1583 a continuación de Los Nombres de Cristo, en su primera edición. Dedica el trabajo u María Valera Osorio que había contraído matrimonio recientemente. Estaba empa- 
rentada con el poeta. Éste quiere darle una serie de normas cristianas que la orienten en su nuevo estado. Para ello Fray Luis acude a su venero permanente: la Biblia. La perfecta casada toma como inspiración a la mujer del último capítulo de los Proverbios. Los necios, que tan poco toleraba nuestro poeta, tuvieron en esta obra motivos para atacarle. Es el libro más editado de la creación luisiana. Muchos quisieron imitarle. Fray Luis tuvo presente la obra de Luis Vives «De Institutione Feminae Christianae». Como comenta el P. Félix García, «la originalidad de Fr. Luis, y en lo que supera a Vives con mucha ventaja, es no sólo en la maravillosa calidad del estilo, en la gracia y bizarría de la exposición, en la riqueza de los conceptos, sino también en la serie de observacioneś finísimas, en la penetración psicológica del alma femenina, en la ponderación de sus virtudes y en la censura valiente, y a veces irónica, de sus defectos y malos siniestros, como él dice»' '. Se trata, por tanto, de una obra de doctrina cristiana, de pedagogía del buen obrar de la mujer. Se ve la naturaleza casi exclusivamente desde un punto de vista ético: es el elemento nuevo respecto a los descubiertos en la Exposición del Cantar. Encontramos la maestría del escritor en las atinadas observaciones sobre el mundo femenino y sobre la sociedad de la época. Es una serie de aguafuertes que denotan un espíritu de observación y fidelidad a lo real y que están referidos a los diversos tipos de mujeres que conoce. Son retratos de la vida de los hombres, no de la naturaleza. Eso sí: nos revelan esa preocupación constante por conocer las cosas tal como son. Su oficio es aquí el de guía de museo.

Conforme a esto, Fray Luis explicará los detalles de la mujer melindrosa o prudente, perezosa o trabajadora, necia o sabia.

Lo más interesante y nuevo es el sentido ético que toma aquí el tema de la naturaleza. Más adelante hemos de estudiar con amplitud este punto de vista para ponerlo en relación con otros autores del Siglo de Oro y desentrañar su significación en la historia del pensamiento. Por ahora nos basta dejar constancia de este hecho. Al ser La perfecta casada una obra de didáctica cristiana, el poeta acude frecuentemente a la naturaleza como fuente de valores éticos. Así encontramos el tema de la alabanza de aldea y de la vida del campo, tan trascendente durante el Siglo de Oro. A la vez que este tema se vincula a la idea de una vuelta a lo espontáneo y a la estética del bucolismo, implica también otras actitudes mentales que tienen ramificaciones de tipo sociológico. En Fray Luis la naturaleza está siempre asociada a los problemas vitales del hombre. Él defenderá al colono que se pasa la vida trabajando las tierras del señor, para que éste haga una vida muelle; él describirá la aurora con los más hermosos colores, y ello para ponderar la belleza que el señor, perezoso y amigo de la cama, se pierde por no madrugar. La descripción es de serena armonía clásica.

1. Op. cit. 223. 
A continuación encontramos también algo de aquel sentimiento de comunicación que veíamos en el Cantar. No es tan intenso porque está estilizado bajo el tono clásico de esta mañana:

\begin{abstract}
«Pues el cantar de las aves, ¿qué duda hay sino que suena entonces más dulcemente? Y las flores y las yerbas y el campo todo despide de sí un tesoro de olor. Y como cuando entra el rey de nuevo en alguna ciudad se adereza y hermosea toda ella, y los ciudadanos hacen entonces plaza y como alarde de sus mejores riquezas, así los animales, y la tierra y el aire y todos los elementos, a la venida del sol, se alegran y, como para recibirle, se hermosean y mejoran y ponen en público cada uno con sus bienes» ${ }^{2}$.
\end{abstract}

Es de notar que en la expresión «tesoro de olor» tenemos una de las pocas sensaciones olfativas de la obra de Fray Luis donde prevalecen absolutamente las visuales y las olfativas. El poeta debió de ver muchos amaneceres cuando la negra melancolía le hacía estar la noche en vela. Los párrafos con que termina esta descripción de la aurora son una expresión de la intimidad del poeta. Es algo de aquella vivencia de infinitud entre el hombre y las cosas que veíamos en el Cantar y en la Celestina. Es el elemento de sensualidad, despojado de erotismo, del que ya hemos hablado anteriormente:

«Porque no es gusto de un solo sentido, sino general contentamiento de todos; porque la vista se deleita con el nacer de la luz, y con la figura del aire, y con el variar de las nubes; a los oídos, las aves hacen agradable armonía; para el oler el olor que en aquella sazón el campo y las yerbas despiden de sí, es olor suavísimo. Pues el frescor del aire de entonces tiempla con grande deleite el humor calentado con el sueño, y cría salud y lava las tristezas del corazón y no sé en qué manera le despierta a pensamientos divinos, antes que se ahogue en los negocios del día» ${ }^{3}$.

Madrugadas y amanereces que gustaban a Fray Luis con la ciudad de Salamanca al fondo: en los dos días en que tienen lugar los diálogos de Los Nombres de Cristo, los personajes se levantan muy temprano. Al comienzo del libro III nos dice que Sabino, el poeta, había salido al campo al romper el alba, donde encontró a Juliano que ya andaba por las cuestas de La Flecha mucho antes que amaneciese. El alba, el crepúsculo y la noche son los momentos del día preferidos por Fray Luis. Las primeras y las últimas horas son el símbolo de lo cambiante, de la realidad aparente que está en continuo devenir. La aurora y el anochecer suponen una vinculación entre el momento cenital del mediodía y el absoluto de la noche que es una llamada continua a la búsqueda de lo esencial. Nuestro poeta ha sabido darnos algunas pinceladas, también de sabor clásico, del crepúsculo:

«... porque siempre, al caer del sol, se levanta un aire blando, y las sombras

2. Op. cit. 274. La perfecta casada, 6 .

3. Op. cit. 274. La perfecta casada, 6. 
que al mediodía estaban sin moverse, ál declinar del sol crecen con tan sensible movimiento, que parece que huyen ${ }^{4}$.

Tenemos aquí la preocupación filośofica de Fray Luis por el problema del fluir de las cosas que él expresará de muchas maneras, pero cuya formulación más feliz gira siempre en torno a la naturaleza.

Por el momento, sea suficiente este recorrido por La perfecta casada. Como la naturaleza presenta aquí una problemática general de raíz filosóficoética, nos ha parecido mejor llevar el análisis completo del tema a un capítulo en que estudiemos su significación conceptual fuera del marco de la estructura literaria.

\section{III. «LOS NOMBRES DE CRISTO»}

La obra «De Los Nombres de Cristo» se publicó por primera vez en Salamanca, en 1583, en la imprenta de Juan Fernández. Al final aparecía el tratado de La perfecta casada. En una segunda edición, hecha también en Salamanca por los herederos de Matías Gazt en 1585, se publican los Nombres con un tercer libro y el de Pastor intercalado entre los de Camino y Monte, del primer libro. Hacen un total de tre€e nombres. Más adelante, y muerto ya Fray Luis, Juan Fernández añade el nombre de Cordero al final de la obra, en la edición de 1595, en Salamanca. Con ello tenemos los catorce nombres que hoy leemos. A la composición primitiva de los cinco nombres del primer libro más los cuatro del segundo sucede otra de 6-4-3 que, al publicar el nombre de Cordero, que debería ir incluido entre el de Hijo y Amado, queda 6-4-4. La obra se edita de nuevo en 1663 y ya no volverá a salir de los tipos hasta 1770, en Valencia. Desde entonces Los Nombres de Cristo comenzarán a subir en la estimación de la crítica hasta convertirse en una de las más altas cumbres de la literatura, el lenguaje y el pensamiento religioso español.

Son conocidas las opiniones dispares que esta obra ha suscitado: desde la minimización de Ortega o Azorín hasta las más bellas páginas de Menéndez Pelayo o la crítica mesurada y fina de Federico de Onís. Se trata de una obra más ponderada que leída, como todas las grandes obras; y sin una lectura pausada y repetida es imposible una crítica ajustada. Así ocurre que vamos repitiendo juicios casi mecánicamente, sin detenernos a investigar el sentido de las cosas. La urgencia de un artículo o un libro seca la fuente de mucha ciencia.

4. Op. cit. 103. Cantar, 2,17. 


\section{La estructura de la obra}

Si queremos ver toda la significación que el tema de la naturaleza y el paisaje tiene en Los Nombres de Cristo, hemos de averiguar antes su composición estructural para determinar después su función en relación con los distintos planos de la creación artística. Nos fijaremos en la marcha de la obra desde el punto de vista del tema de este trabajo. Intentaremos una síntesis que nos ayude en nuestro análisis.

Comienza la obra con una dedicatoria a don Pedro Portocarrero, gran amigo de Fray Luis, que fue Rector de la Universidad de Salamanca en dos ocasiones, y a quien el poeta dedicó, además, dos odas y su «Explanatio in Abdiam Prophetam». Otra dedicatoria al mismo Portocarrero precede a los dos libros siguientes. Cada uno de los tres libros en que está dividida la obra es precedido de una introducción en que el escritor describe el lugar en que se desarrollan los diálogos. Los personajes son tres: Marcelo, el escriturario; Juliano, el teólogo escolástico y Sabino, el poeta. Comienza la conversación en la mañana del 29 de junio, día de san Pedro. Al mediodía termina la conversación, y el primer libro. Tiene lugar en la huerta de La Flecha, a la sombra de unas parras y junto a una fuente. La finca está a las orillas del río Tormes, muy cerca de Salamanca. "El día era sosegado y purísimo, y la hora muy fresca», resume Fray Luis. En'estos diálogos de la mañana se desarrollan seis nombres, conforme a la edición de 1585 . Termina el libro primero con el nombre de Padre del Siglo Futuro. Sabino recita el salmo 103, según la traducción de Fray Luis, lleno de sabor y júbilo de la naturaleza. El sol lo baña todo con su plenitud: es mediodía.

El libro segundo comienza con un sintagma ilativo que enlaza el diálogo con el primero. Tal como había sugerido Sabino, el poeta, los tres frailes cruzan el Tormes en una balsa hasta una isleta o soto que había en medio. Un pequeño arroyo corta el soto por la mitad. Se sientan en lo más espeso, junto a un álamo que dejan a sus espaldas. Enfrente tienen la otra parte del soto. Se inicia el diálogo después de la hora de siesta del mismo día de san Pedro y termina ya muy entrada la noche pués, al comienzo de «Príncipe de la paz», el cielo está lleno de estrellas y, al final del último nombre, «Esposo», nos dice el escritor que «ya muy entrada la noche, los tres se volvieron a su lugar». Sabino, como al final del primer libro, recita aquí un salmo, el 44.

El libro tercero se desarrolla al día siguiente, 30 de junio, conmemoración de san Pablo. Después de la dedicatoria, Fray Luis nos presenta a Sabino y a Juliano encontrándose, al romper el alba, en el camino que va hacia Salamanca, y que está a la derecha de la casa de la finca. Después de conversar y esperar un rato, van a despertar a Marcelo. El sol está ya alto. Los tres deciden reanudar el diálogo en el soto, después de la siesta, como en la tarde anterior. Después de comer, Marcelo descansa en la casa, Juliano se sienta entre los áląmos y Sabino pasea de un lado a otro. Por la mañana habían establecido que 
Marcelo desarrollara el nombre de «Jesús» y Juliano otro que él mismo escogería a su gusto. Vemos que después hay un cambio de plan ya que tratan tres nombres más el de "Cordero», que se publicó en 1595. En este libro tercero, ya desde un principio, se observa una mayor indecisión en el plan general. Pasada la siesta los tres frailes suben a la barca y pasan al mismo lugar del soto en que habían estado el día anterior. Termina el libro con el salmo 102, también traducido por Fray Luis y recitado por Sabino.

Una lectura atenta nos muestra una diferencia de plan entre los dos libros primeros y el tercero. Lo veremos reflejado en el tema de la naturaleza. Vemos, en primer lugar, que Fray Luis no debía de tener un propósito claro de continuar la obra con un tercer libro. Por lo que Sabino dice a Marcelo en la introducción de este último libro, sabemos que el nombre de «Jesús» no esłaba en el plan primitivo. La razón que da Marcelo es lo mucho que ya se había escrito sobre él, no su olvido. Una vez que han decidido que éste desarrolle dicho nombre, nos sorprende que trate antes el de "Amado». Juliano trata en primer lugar el de «Hijo de Dios», uno de los más extensos de la obra. Sabemos, además, que el nombre de «Cordero» tenía que ir intercalado entre el primero y el segundo. Por otra parte, las alusiones y continuas referencias al paisaje que vemos en los dos primeros libros están ausentes en el último, con la excepción del pasaje de la avecica. Es también muy diferente la adecuación de tema, tiempo y naturaleza. En la estructura del contenido hay en «Hijo de Dios» claras afinidades con el de «Pimpollo» o «Faces de Dios». Son comprensibles estas vacilaciones: ocurre que, durante la noche del día de san Pedro al de san Pablo, han pasado varios años en la redacción de los ensayos.

El plan y la vinculación entre el tema, la composición, los personajes y el paisaje aparece más claro en los dos libros primeros. Atendiendo al contenido vemos que el escritor comienza con la consideración de Cristo como «Pimpollo», es decir, como parto común de las cosas. La contemplación de la belleza del mundo ha de hacernos ir a la belleza suprema de Cristo. Nacido como Fruto de todas las cosas Cristo es la imagen de Dios, como vemos en «Faces de Dios», y es el camino para ir a Él. Según la metáfora bíblica Cristo es Pastor de los justos y es abundante en pastos, como un Monte. Por Cristo el hombre ha de nacer a segunda y nueva vida. En todo el libro primero el contenido se desarrolla a base de metáforas de la naturaleza en el plano de lo simbólico. Aquí la naturaleza es signo, en gran medida.

El segundo libro comienza, como decíamos, con un sintagma ilativo que refuerza la conexión entre éste y el primero:

«Porque fue así, que los tres, después de haber comido y habiendo tomado algún reposo, ya que la fuerza del calor comenzaba a caer, saliendo de la granja, y llegados al río que cerca de ella corría, en un barco, conformándose con el parecer de Sabino, se pasaron al soto que se hacía en medio de él, en 
una como isleta pequeña, que apegada a la presa de una acequia se descubría»'.

Cristo es «Brazo de Dios» que colabora con el hombre para vencer al pecado, y es Rey y es Señor. El nombre de «Príncipe de la paz» nos lleva a consideraciones de orden filosófico tanto como místico y teológico. Es uno de los nombres más bellos y significativos. Ya Alain Guy ha estudiado ampliamente el significado de la paz en Fray Luis ${ }^{2}$. A. Guy hace énfasis en la hondura filosófica que revela el desarrollo del pensamiento del escritor salmantino. Con el nombre de «Esposo» termina el libro II en una exaltación mística.

Desde la concepción de Cristo como parto común de todas las cosas, hemos venido a cerrar la curva del pensamiento al volver a Cristo a las cosas, puesto que Cristo se unió a lo corpóreo tomando la forma del hombre y uniéndose a él cada día mediante la comunión religiosa. A las consideraciones más táctiles e inmediatas del libro primero, han sucedido otras más indefinibles donde, a la vaguedad de un sentimiento estético de la noche estrellada, como se ve en «Príncipe de la paz», se une la zona sin fronteras del nombre de «Esposo». Veremos también que el paisaje y el tema han ido cambiando al mismo tiempo. La naturaleza y la vista de La Flecha no son aquí algo añadido, sino enraizado en la misma entraña del tema. A un mismo tiempo los tres personajes han ido cambiando también. La naturaleza y el paisaje establecen la comunicación entre Cristo, las cosas y las personas. Lo que a nosotros nos interesa es averiguar la función que la naturaleza y el paisaje desempeñan en cada uno de los tres planos más destacados de esta obra: el plano de la composición o la estructura, el plano del tema o del símbolo y el plano de los personajes o la comunicación.

\section{Plano de la composición: Función de la naturaleza en la estructura literaria}

Se ha dicho que el paisaje de Los Nombres de Cristo es el marco en que tiene lugar la simbología de la teología cristiana. Esta idea ha pasado, sin crítica alguna, a las páginas que se han dedicado a este tema. Ello viene motivado por la falta de un análisis detenido del significado profundo que el paisaje y la naturaleza tienen en esta obra. Como dice Roland Berther, el hombre es un fabricador de signos. Los elementos de una composición han de verse en relación con el conjunto. Separarlos de la arquitectura total es desproveerlos de su auténtico valor. Al considerar un elemento únicamente en sí mismo, le despojamos de la multiplicidad de sentidos que el creador ha puesto en él al situarlo en una estructura dentro de otras unidades de significación. Cada ele-

1. Op. cit. 517. Dedicatoria Libro II.

2. Alain Guy. La pensée de Fray Luis de León, Limoges, 1943. 
mento tiene su función específica. Su valor puede comprobarse por el vacío que deja el conjunto, al separarlo de él. Sólo una mirada superficial puede minimizar la significación que el paisaje y la naturaleza tienen en esta obra. Para detectarla, hemos de descubrir el principio organizador de la composición porque «si, al analizar la composición de cualquier obra literaria no alcanzamos a descubrir el principio ordenador en que se apoyó el autor, se nos escapa su estructura y la obra parece sin orden ${ }^{3}$. Hemos resumido ya brevemente el plan general y el avance de la obra. La labor que ahora tenemos delante es la de indagar en la función que el tema de la naturaleza desempeña en el plano de la composición.

Lo primero que tenemos que hacer es una distinción clara de la naturaleza tomada como lenguaje referencial y como referente. Como lenguaje referencial la naturaleza es aquí un elemento que apunta a Cristo; como referente, la naturaleza es un elemento con substantividad propia, que se centra en los límites concretos y geográficos del paisaje de La Flecha. Como lenguaje referencial, la naturaleza está dentro de la inspiración bíblica y la corriente mística del Siglo de Oro español. Ya la Edad Media había visto las cosas como símbolos de Dios. Tenemos que tener en cuenta la idea antigua que toma auge en Sabunde de que el universo es un libro que hay que descifrar. Por influjo de la Cábala judaica se dijo que era un geroglífico, un sistema de signos. Esta idea persiste en el Renacimiento y llega hasta Galileo. En los Nombres hay mucho más: lo que se percibe en la naturaleza es una cercanía de lo religioso y lo material donde la naturaleza y Dios se.miran; ella es colaboradora del hombre en su peregrinar hacia lo eterno. Son los ecos del salmo 18: Coeli enarrant gloriam Dei. La naturaleza, como referentè, pertenece ya a la nueva forma de mirar del Renacimiento. El mundo exterior es algo independiente del hombre. La misma actitud espiritual que llevó a Copérnico al estudio de los antiguos y a la observación del mundo exterior tal cual aparece, es la que lleva a Fray Luis de León a mirar con unos ojos de asombro, nuevos en la cultura hispánica, las cuestas y los árboles y el río Tormes y los fondos de La Flecha.

\section{A. La forma dialogada}

Dentro de la composición de la obra lo primero que se nos ofrece es su condición de forma dialogada. Puede que esto tenga importancia en relación con el destacado papel que aquí desempeña el paisaje. En una estructura dialogada el problema base es el de resolver la unidad del conjunto. Esto se agrava si se trata de una obra como Los Nombres de Cristo en que unos diálogos se superponen a otros. Es una serie abierta y ello entraña el peligro de la

3. OldRich Betic, Análisis estructural de textos hispanos, Madrid 1969, pág. 58. 
difusión de la unidad literaria y temática. La habilidad del escritor estará en dar una sólida contextura formal al diálogo.

En todo diálogo consideramos el contenido, por un lado, y los personajes que desarrollan ese contenido, por otro. La unidad de la composición suele venir dada por la arquitectura doctrinal. Los personajes actúan desde fuera. Claro está que la estructura dialogada puede venir matizada de dramatismo interno, como ocurre en el Fedón, de Platón, cuando uno de los personajes forma parte de la significación completa de la obra. En este sentido Los Nombres de Cristo son diálogos al estilo platónico. En otro aspecto Helen Dill ha mostrado la voluntad de Fray Luis de seguir la cláusula retórica de los latinos ${ }^{4}$. La base fundamental que diferencia estos diálogos de los ciceronianos es que en ellos los personajes, a la vez que van desarrollando el tema se ven influidos por la corriente del contenido, y por el paisaje y el momento del día con el que coincide el diálogo. Así ocurre en el nombre de Esposo, por ejemplo, donde Marcelo corta el diálogo para dirigirse a Cristo en segunda persona. Son movimientos del espíritu místico que también encontramos en santa Teresa. Con frecuencia se sorprende Marcelo llevado del hilo de la narración, y tiene acentos que recuerdan a la santa de Ávila: «Salido he de mi camino, llevado de la golosina del verso; mas volvamos a él» ${ }^{5}$. En otro lugar leemos: «Y dicho esto, calló Marcelo, todo encendido en el rostro; y suspirando muy sentidamente, tornó luego a decir:

«No es posible que hable el enfermo de la salud...» ${ }^{6}$.

Tendremos ocasión de comprobar la influencia del paisaje y de la hora sobre el espíritu de los personajes que van cambiando su tiempo psicológico con el sol y las sombras que oscurecen la noche.

\section{B. La naturaleza como elemento subyacente de la composición}

Encontramos en los Nombres de Cristo una frescura singular que está ausente de los demás diálogos doctrinales renacentistas. Se trata de hacer un libro en que la teología cristiana se ponga al alcance de todo el mundo, incluso de las doncellas que llevan continuamente en sus bolsos libros de amoríos. Lo que sucede es que, al incidir el paisaje de Los Nombres sobre la composición y los personajes, presta a la obra un tono de comunicación que está más allá del objetivismo del diálogo doctrinal. La naturaleza trae el sentido de la comunicación a las cosas y a los hombres. En realidad está de acuerdo con la idea platónica, muchas veces repetida en Los Nombres, de que el amor es el substrato

4. Helen Dill Goode, La prosa retórica de Fray Luis de León en «Los Nombres de Cristo», Madrid 1969.

5. Op. cit. 635. Lsposo.

6. Ib. 468. Monte. 
que mantiene en tensión y unidad el mundo entero. Como veremos más adelante, la naturaleza llega a convertirse en un personaje más de la obra a la vez que forma la estructura subyacente en la que se apoya la unidad que toda obra del pensamiento exige. La naturaleza es, además, la encargada de llevar al hombre a Cristo y de traer a Cristo al hombre. El paisaje y la naturaleza posibilitan la comunicación con el tema:

El problema que se plantea al escritor es cómo centrar la composición dentro de unos límites. Competir con los libros de caballerías y de poesía amorosa que leían las gentes implica una amenidad que no suelen tener los libros puramente doctrinales. En Los Nombres la dificultad se agrava por la tradición escolástica de exponer la teología. El silogismo encadena la mente, pero no la imaginación del lector, y a estas alturas del Renacimiento, cuando la aventura de los siete mares y de los parajes nebulosos de los libros de caballerías llamaba a la imaginación calenturienta del español, encadenar la facultad imaginativa era algo muy importante para el escritor religioso. De sobra lo sabían los autores ascéticos de la época. Un gran hombre del Renacimiento español sabrá aprovechar en sus Ejercicios Espirituales la exaltada imaginación hispánica: san Ignacio de Loyola presentará, audaz y concisamente, las más truculentas escenas infernales. El Renacimiento apela a la imagen a la vez que a la razón, es decir, apela a la poesía y a la ciencia. Fray Luis tenía que atar la imaginación del lector y tenía que dar un hilo de composición a su obra.

El situar el diálogo en un marco, en un escenario estático, había sido patrimonio de la estética pre-renacentista. De aquí podemos inferir también una explicación al simbolismo que la naturaleza tenía en la Edad Media. Una naturaleza estática tiene las condiciones de inmovilidad y fijeza que caracterizan al símbolo. Pero la naturaleza del Renacimiento está dotada de fuerza propia, es móvil. Fray Luis participa de esta concepción. Así, pues, tenemos en Los Nombres de Cristo dos mundos de creación: por un lado, el elemento tradicional y medieval, que es la dotrina teológica. Este elemento es estático en el sentido de que está ya determinado y elaborado por una teología. Por otro lado, la naturaleza presta movilidad a este factor estático, y es principio de composición. Es necesario un elemento móvil sobre el que se construya la arquitectura total. Dicho elemento podría venir dado por el tema mismo y, en efecto, la esctructura del contenido nos da una cohesión desde el principio hasta el final. Pero esto no basta. Se requiere una estructura formal que responda, en la forma exterior, al arco de la forma interior. Lo que hace Fray Luis es mover el tiempo y el paisaje y vincular el contenido de Los Nombres a sus diferencias. La falta de una acción que dé interés y unidad se compensa aquí con la función unitiva y dinámica que el paisaje y el momento del día desempeñan. El comienzo de los diálogos es una de las más bellas oberturas de la literatura española. El resto de los tratados queda atado a este paisaje inolvi- 
dable. Fray Luis ha puesto todo su sentido del ritmo en los pentagramas de estas líneas:

«Era por el mes de junio, a las vueltas de la fiesta de San Juan, al tiempo que en Salamanca comienzan a cesar los estudios, cuando Marcelo, el uno de los que digo - que así le quiero llamar con nombre fingido, por ciertos respetos que tengo, y lo mismo haré a los demás-, después de una carrera tan larga como es la de un año en la vida que allí se vive, se retiró, como a puerto sabroso, a la soledad de una granja que, como V.M. sabe, tiene mi monasterio en la ribera del Tormes; y fuéronse con él, por hacerle compañía y por el mismo respeto, los otros dos. Adonde habiendo estado algunos días, aconteció que una mañana, que era la del día dedicado al apóstol San Pedro, después de haber dado al culto divino lo que se le debía, todos tres juntos se salieron de la casa a la huerta que se hace delante de ella»" ${ }^{7}$.

En los dos primeros libros, especialmente, vemos que la secuencia de un nombre respecto de otro no puede variarse sin detrimento del conjunto. Hay referencias al paisaje y al momento del día que arrastran la gradación de los tratados. Es más: éstos dependen en su tratamiento de la hora y el paisaje. Así, por ejemplo, el nombre de «Príncipe de la paz» está tratado en función del momento y la visión de la noche estrellada a donde han llegado los tres frailes después de un día entero de conversación. Sabemos de la relación intima que media entre la paz y la visión estética de la noche en Fray Luis. No es posible situar este nombre al comienzo del libro. Hay una vinculación estrecha entre paisaje, nombre y ánimo de los personajes. En definitiva, hay una comunicación y un ritmo triple que es el paisaje quien lo impone.

\section{Perspectiva visual y perspectiva estética del contenido}

Podríamos decir que el ritmo de los Nombres sigue el de la perspectiva visual y anímica. La perspectiva parte de una línea horizontal hacia otra vertical. Esto ocurre tanto en la organización de los Nombres como en el paisaje. Es indudable que por la mañana se destacan más las líneas horizontales. La fuente corre «estropezándose»; delante de ellos tenían una hermosa alameda; más allá el Tormes corta el paisaje. Es decir, hay una proyección de la vista que es horizontal y frontal. Es la proyección de las primeras horas de la mañana, cuando las sombras esculpen sobre la tierra la longitud de los árboles y los elementos de la naturaleza. Vemos a los tres frailes sentados a la sombra de unas parras. Las sombras irán desapareciendo a medida que avanzan las horas. Todo desaparecerá ante la verticalidad fulgurante del sol en el cénit. Ocurre al final del libro primero. Por la tarde tenemos la misma perspectiva horizontal, al comienzo del libro segundo, que se irá tornando a vertical con la

7. Op. cit. 392. Introducción libro I. 
llegada de la noche en que se inmoviliza para colaborar en las manifestaciones líricas y estéticas del nombre Príncipe de la paz.

En el libro III aparece que Fray Luis ha olvidado la inspiración primitiva. El paisaje tiende a ser puro marco. A nuestro modo de ver el libro III no responde a la inspiración y sentimiento de la naturaleza que preside los dos primeros.

A la perspectiva visual del paisaje corresponde otra estética en el tratamiento de los Nombres. En una obra tan organizada no podemos pensar que la secuencia de los tratados sea algo casual. En la edición de 1585 Fray Luis añade el libro III y el nombre de Pastor que intercala entre los de Camino y Monte. No nos parece que sea puro azar esta colocación. Responde al lenguaje referencial que la naturaleza tiene en esta obra. Cristo vive en los campos, y «Camino» $\mathrm{y}$ «Monte» son nombres que se refieren a elementos geográficos o del campo. Pero lo que más nos inclina a pensar así es la perspectiva. Vemos claramente que, al sentarse los tres frailes, sólo se ocupan de su contorno inmediato. Al pasar las horas van fijándose en perspectivas que están cada vez más lejanas, hasta encontrar algo que cierra la proyección de la vista, un monte, el mismo que tiene delante el poeta cuando escribe la oda «Descanso después de la tempestad». Ahora se vuelve, como en una coda, al tema del primer nombre que era el de la generación, sólo que bajo un punto de vista diferente: es el nombre «Padre del Siglo Futuro». En este avance de la perspectiva «Pastor» ha de estar en medio, en el campo lejano y amplio, cerca de los montes que es por donde andan los pastores. Pensamos que la secuencia de los Nombres es, en gran manera, de orden estético, y acompaña a la perspectiva del paisaje. Hay también una gradación en el contenido, pero nos parece que ha sido adaptada a la perspectiva de la naturaleza que el escritor tiene delante.

\section{La poesía y la naturaleza}

En «Pimpollo» tenemos una visión general de la naturaleza: los cielos extendidos, las estrellas, la luz, la tierra pintada de flores, los animales. El nombre de «Faces de Dios» tiene acentos místicos. La perspectiva es más cercana, del contorno inmediato: aquí Cristo cuida de los pajarillos que serían los mismos que cantaban - como Sabino- entre los bien poblados árboles. La vista se levanta después hasta ver el camino que va a la Corte. Realmente podemos pensar que Fray Luis toma datos del medio ambiente geográfico en que se encuentra para aclarar sus ideas teológicas, pero también puede ser que los Nombres hayan sido sugeridos o adaptados al lugar en que se encuentra, y que llega a convertirse, como elemento literario, en el elemento que soporta la unidad de la obra. De esta forma el paisaje no es sólo escenario, sino motor de la composición.

De este cruce de ideas y estética es claro eiemplo «Monte». Es conocida la 
definición que allí hace Fray Luis de poesía como «una comunicación del aliento celestial y divino». Lo que es interesante es analizar el contexto en que está hecha esa exaltación de la poesía. De nuevo tenemos que recordar que no se puede ver azar en ninguna gran creación, pero mucho menos en Los Nombres de Cristo, donde han sido pesadas las palabras y vibradas, como un diapasón, para distinguir su sonido. Ha de tener algún sentido esta exaltación de la poesía precisamente en este nombre. «Monte» es uno de los nombres más naturalistas de la obra. Aparece a la vez con valor substantivo y como lenguaje referencial de Cristo. En los montes están los principios de los ríos que, cayendo a los llanos y torciendo el paso por ellos, fertilizan y hermosean las tierras. Los altos montes se tocan de nubes y en sus faldas se crían viñas y mieses y pastos para los ganados. Allí encontramos el trigo, el vino «y el óleo, hijo de la oliva y engendrador de la luz, que destierra nuestras tinieblas» ${ }^{8}$. En este mismo nombre Marcelo, llevado de la inspiración, cita una traducción del salmo 71 que había hecho el amigo común de todos ellos, es decir, Fray Luis. El salmo 71 es un bello ejemplo de la naturaleza como lenguaje referencial de Dios. Y aquí es donde Sabino, el poeta, interrumpe a Marcelo para preguntarle por el auténtico objeto de la poesía. Por tanto, la exaltación de la poesía como comunicación divina viene traída de la mano de un salmo que se refiere a Dios bajo el lenguaje referencial de la naturaleza. Como veremos al tratar de las poesías, las composiciones más elevadas de Fray Luis hacen lugar, de una u otra forma, a la naturaleza. El que surja el tema de la poesía en el nombre de «Monte», tan naturalista, y a propósito de un salmo del mismo sabor, viene a confirmar la relación que se da en toda la obra de Fray Luis entre la creación literaria, el pensamiento y la naturaleza.

La perspectiva ha ido alejándose buscando la vertical del monte. Allí encuentra una invitación a la prolongación hacia el firmamento luminoso que es lo que vemos al final del último nombre. El postrer detalle al que ponen atención los tres frailes, antes de irse a comer y terminar el libro I, es que el sol molesta ya, levantado sobre sus cabezas. En el contenido se ha vuelto a la inspiración del primer nombre; en la perspectiva el sol ha cortado, cegadoramente, la vertical con su plenitud de luz. Ya no hay perspectiva ni sentido de fondos ante tanta verticalidad. Hemos de esperar a que pase la siesta y las sombras vuelvan a definir la posición de los elementos de la naturaleza para comenzar el diálogo de nuevo. Tendremos el mismo ritmo: de una perspectiva horizontal a otra vertical que ahora será la noche estrellada.

\section{E. El libro II y la noche estrellada}

Lo primero que se advierte al leer el libro II es que Fray Luis sólo trata aquí cuatro nombres frente a los seis del primero; sin embargo, la extensión es

8. Op. cit. 465. Monte. 
prácticamente la misma. La situación es ahora más meditativa, menos móvil. El discurso se alarga y hay pocas cosas alrededor que interrumpan a los personajes. En el libro I todos los nombres hacián referencia a la naturaleza, en alguna manera; en el II la visión más bucólica de la naturaleza se va a tornar en visión del universo, de la noche, de los astros, del firmamento. Esta contemplación estética cạe también dentro de la más genuina mirada renacentista. El paisaje - lo llamamos así por extensión- de las estrellas era familiar a los marinos o geógrafos que recorrían los mares o trazaban portulanos y dibujaban mapas con una técnica celosamente guardada. La armonía de las estrellas representaba también la preocupación filosófica por la unidad. Es, al fin y al cabo, la salida del hombre humanista para contemplar el mundo y tratar de encontrar un elemento de unidad en todo para unir un mundo en escisión. La claridad del día ha dado paso a un intimismo que se acerca a lo místico.

El escritor describe el soto en términos semejantes a los de La Flecha:

«Era el soto, aunque pequeño, espeso y apacible, y en aquella sazón estaba muy lleno de hoja; y entre las ramas que la tierra de suyo criaba tenía también algunos árboles puestos por industria, y dividíales como en dos partes un no pequeño arroyo que hacía el agua que por entre las piedras de la presa se hurtaba al río, y corría cuasi toda junta» ${ }^{9}$.

Con el crepúsculo va desapareciendo poco a poco la horizontal, que es la línea dominante en la descripción del soto. Al final de Brazo de Dios Juliano levantará los ojos para ver que el sol ya se pone. En la transición del crepúsculo a la noche cerrada se trata el nombre Rey de Dios. Al terminar, Marcelo alza los ojos al cielo que ya está cubierto de estrellas, y así comienza Príncipe de la paz. A la movilidad del paisaje matinal, donde Marcelo podía apuntar al camino de la Corte o escribir unas letras en la tierra, ha sucedido la quietud y la ausencia de paisaje colorista que es compensada con la presencia de la noche estrellada. Hay que recordar todo lo que la noche estrellada significa para Fray Luis. Si el paisaje matinal y luminoso del primer libro ofrecía motivos continuos al escritor para la composición de la obra, aquí ocurre una penetración en su intimidad. El nombre de «Príncipe de la paz», aparte su valor filosófico y místico, es el que nos muestra más claramente la corriente de comunicación que se da entre la naturaleza y los personajes de los diálogos. Éste proceso había comenzado en la conversación de la mañana superponiéndose a la estructura de la obra. A la objetividad y jerarquía de la perspectiva visual sucede esta negación de distancias en que todo se confunde, y el hombre y.la naturaleza se sienten colaboradores. A falta de esta perspectiva, toda la naturaleza se cuela de rondón en el espíritu del poeta.

La naturaleza es también aquí el soporte del tema. La armonía de los cielos es principio estético que lleva a los astrónomos renacentistas a plantear

9. Op. cit. 517. Introducción libro II. 
el problema del movimiento del universo. Es curioso observar cómo fueron las ideas estéticas las que hicieron al hombre mirar con ojos de maravilla al cosmos y le llevaron a descubrir sus secretos y formularlos en términos matemáticos y geométricos. Este sentimiento de armonía que el matemático aplica a sus elucubraciones, Fray Luis lo relaciona con su pensamiento ético y encuentra en la armonía del cielo estrellado el más claro ejemplo de lo que significa la armonía de la paz. El escritor va acompasando su pluma al ritmo que le impone la naturaleza exterior. Esto es algo nuevo en la literatura y el pensamiento español. Durante la Edad Media el hombre había impuesto sus categorías a las cosas. Ahora es la naturaleza quien obliga e impone su realidad objetiva. La aparición del paisaje en la pintura del Renacimiento, aunque todavía como fondo, supone una afirmación del mundo ante el hombre que antes no se conocía. Incluso dirige y condiciona su creación. Lo nuevo de Fray Luis es este supeditar su creación al momento y al paisaje que tiene delante. La naturaleza actúa como el soporte que da unidad a la composición.

Al analizar la Exposición del Cantar de los Cantares, comentamos el sentido de fidelidad a lo real de nuestro poeta. También lo encontramos en las detalladas descripciones de Los Nombres de Cristo y en el llamamiento continuo al contorno. Al comienzo de «Príncipe de la paz» Marcelo mira al cielo y recoge la vista hermosa y concertada que las estrellas forman en la noche salmantina.

En el nombre «Esposo» no hay referencias tan abundantes a la naturaleza, pero es indudable la vinculación que hay entre la noche y el carácter místico de este nombre. Una simple prueba de conmutación nos haría ver que éste es el lugar propio para este nombre. No podríamos colocarlo en vez de «Paśtor» o «Camino», por ejemplo, Detrás de «Esposo» hay toda una filosofía mística en que la noche juega un papel de primera magnitud. El libro II termina como el primero, con el salmo 44 recitado por Sabino y una indicación sobre la hora, que nos confirma esa fidelidad a lo real de que hemos hablado: "y dicho esto, y ya muy de noche, los tres se volvieron a su lugar» ${ }^{10}$. Hay otro detalle curioso de este respeto a la realidad: al comienzo de «Rey de Dios» Sabino, como de costumbre; lee el guión de este nombre; al mismo tiempo adelanta los dos últimos del libro II. La razón que él da es la brevedad:

«Mas es poco todo lo demás que en este papel se contiene; y así, por no desplegarle más veces, quiérolo leer de una vez...»" ${ }^{11}$.

A nosotros se nos ocurre que hay otra razón más realista. Hay que tener en cuenta que el libro II comienza después de la siesta; por tanto, al comenzar el segundo nombre, el de «Rey de Dios», había suficiente luz para leer el papel que Sabino tenía; sin embargo, al final de este nombre, es ya noche cerrada y

10. Op. cit.651. Esposo.

11. Ib. 547. Rey de Dios. 
el autor nos lo hace notar claramente: «Y tornó a callar, y descansando y como recogiéndose todo en sí mismo por un espacio pequeño, alzó después los ojos al cielo, que ya estaba sembrado de estrellas, y teniéndolos en ellas como enclavados, comenzó a decir así...» ${ }^{12}$. Es decir, que cuando los tres frailes comienzan el nombre «Príncipe de la paz» es ya entrada la noche y no hay alcuza que pueda alumbrar a Sabino en lo sucesivo. Es éste un detalle pequeño, pero muy significativo, de la voluntad que tiene el escritor de respetar la realidad externa. Es la preocupación constante por la hora del día y por el paisaje que imponen su realismo a estos diálogos localizados en un determinado lugar y en un tiempo delimitado también.

\section{F. El libro III}

Entre la noche del día de San Pedro y la conmemoración de San Pablo han pasado varios años en la redacción del libro. Observamos que el paisaje ha perdido elementos en la descripción, pero ha ganado dramatismo. Si en los libros I y II el paisaje de la introducción estaba frente a los personajes que, poco a poco, se'iban comunicando con él, en la introducción del libro III vemos una viveza desconocida. Se dan los elementos del paisaje conforme van caminando y conversando los frailes. Los primeros en verse son Sabino y Juliano que han andado por las cuestas de La Flecha:

«El día que sucedió en que la Iglesia hace fiesta particular al apóstol San Pablo, levantándose Sabino más temprano de lo acostumbrado, al romper del alba salió a la huerta, y allí al campo que está a la mano derecha de ella, hacia el camino que va hacia la ciudad; por donde, habiendo andado un poco rezando, vio a Juliano que descendía para él de la cumbre de la cuesta, que, como dicho he, sube junto a la casa. Y maravillándose de ello y saliéndole al encuentro, le dijo: - No he sido yo el que hoy ha madrugado, que según me parece, vos, Juliano, os habéis adelantado mucho más, y no sé por qué causa.

-Como el esceso en las cenas suele quitar el sueño respondió Juliano-, así, Sabino, no he podido reposar esta noche, lleno de las cosas que oímos ayer a Marcelo; que demás de haber sido muchas, fueron tan altas que mi entendimiento, por apoderarse de ellas, apenas ha cerrado los ojos. Así que verdad es que os he ganado por la mano hoy porque mucho antes que amaneciese ando por estas cuestas» ${ }^{13}$.

Hay un detalle curioso: el mundo animal ha entrado en el paisaje. Encontramos menos quietud y más vida. Escuchamos una conversación entre Juliano y Sabino sobre las aves y los peces dicha de un naturalista de la época. Este dramatismo y movimiento lo veremos después más claramente en el epi-

12. Ib. 581. Rey de Dios.

13. Op. cit. 660. Introducción libro III. 
sodio de la avecica. Ha habido una evolución en la concepción luisiana del paisaje: a la naturaleza sonriente y virgiliana de los primeros libros sucede ahora otra más activa. Antes el hombre prestaba sus sentimientos a la naturaleza; hay ahora un ensamblaje perfecto de paisaje y personas moviéndose en él.

Curiosamente, se nos da una razón de por qué el paisaje de la mañana en La Flecha y el de la tarde el soto que a nosotros nos parece extraña, pero que nos puede dar idea de cómo en esta obra nada hay al azar y todo obedece a un plan bien concebido. Sabino sugiere a Juliano que mejor hubiera sido pasear por el río. Es la continuación de los párrafos citados anteriormente:

— «Pues ¿por qué por las cuestas? -replicó Sabino-. ¿No fuera mejor por la ribera del río en tan calurosa noche?

- Parece - respondió Juliano- que nuestro cuerpo naturalmente sigue el movimiento del sol, que a esta hora se encumbra y a la tarde se derrueca en la mar; y así es más natural el subir a los altos por las mañanas, que el descender a los ríos, que a la tarde es mejor.

- Según eso - respondió Sabino- yo no tengo que ver con el sol, que derecho me iba al río, si no os viera.

- Debéis - dijo Juliano- de tener que ver con los peces.

- Ayer - dice Sabino - decía yo que era pájaro.-Los pájaros y los peces -respondió Juliano- son de un mismo linaje, y así viene bien...» ${ }^{14}$.

\section{G. El dramatismo de la naturaleza}

Vemos en el episodio de la pájara que el mundo animal y el dramatismo ha entrado en el paisaje. Este momento dramático contrasta con el nombre «Hijo de Dios», en que se incluye, y que respira paz y triunfalismo. Se ha interpretado este episodio en un sentido simbólico, pero la forma, tan viva, en que está narrado, nos indica, a todas luces, una escena vista alguna vez. La violencia nos sorprende y conmueve en los animales tanto como en los hombres. El ruido amable de la presa se ha trocado en el ruido que hacen dos grandes cuervos en torno a la pájara. El agua, que había sido la noche anterior como otro firmamento, es ahora el elemento donde va a ahogarse la avecica. En la orilla contraria a donde estaban, oyen los tres frailes un ruido que contrasta con el que hace la avecica:

«...y, volviéndose, vieron que lo hacían dos grandes cuervos que, revolando sobre la ave que he dicho y cercándola al derredor, procuraban hacerle daño con la uñas y con los picos. Ella, al principio, se defendía con las ramas del árbol, encubriéndose entre las más espesas. Mas creciendo la porfía, y apretándola siempre más a doquiera que iba, forzada, se dejó caer en el agua, gritando y como pidiendo favor. Los cuervos acudieron también al agua, y vo-

14. Op. cit. 660. Introducción libro III. 
lando sobre la haz del rio la perseguían malamente hasta que. al fin, el ave se sumió toda en el agua, sin dejar rastro de sí. Aquí Sabino alzó la voz, y con grito dijo: - ¡Oh, la pobre, cómo se nos ahogó!» 15 .

Nos muestra aquí Fray Luis una técnica cinematográfica de secuencias rápidas. Hay un corte de suspense, y despues se reanuda la escena:

" $Y$ asi lo creyeron sus compañeros, de que mucho se lastimaron. Los enemigos, como victoriosos, se fueron alegres luego. Mas como hubiese pasado un espacio de tiempo, y Juliano con alguna risa consolase a Sabino, que maldecía los cuervos, y no podia perder la lástima de su pájara, que asi la llamaba, de improviso, a la parte a donde Marcelo estaba, y casi junto a sus pies, la vieron sacar del agua la cabeza, $y$ luego salir del arroyo a la orilla, toda fatigada y mojada. Como salió se puso sobre una rama baja que estaba alli junto, adonde extendió sus alas, y las sacudió del agua; y después, batiéndolas con presteza, comenzó a levantarse por el aire cantando con una dulzura nueva. Al canto, como llamadas otras muchas aves de su linaje, acudieron a ella de diferentes partes del soto. Cercábanla, y, como dándole el parabién, le volaban al derredor. Y luego, juntas todas, y como en señal de triunfo, rodearon tres o cuatro veces el aire con vueltas alegres; después se levantaron en alto poco a poco, hasta que se perdieron de vista" ${ }^{16}$.

La narración de este episodio supone un sentimiento de la naturaleza real y vivido, como no se conocía en la literatura castellana. En un breve espacio se ha pasado de la tragedia al más grande regocijo: es un movimiento fulgurante. Cambios rápidos de cámara fotográfica. Se han tomado los momentos más dramáticos y destacados, y se sugiere el resto. Primero es un ruido que llama la atención; después se pasa de un plano distante a otro más cercano, a medida que aumenta el dramatismo. Se pierde el ave entre las aguas y vuelve otra vez a emerger en primer plano. Vienen los demás pájaros y en un plano hermosísimo se va distanciando toda la bandada, exultante y gozosa, hasta que se pierde de vista.

En el libro III hay menos referencias al contorno. Aparte de la introducción y el episodio comentado apenas hay referencias al paisaje. En el nombre de "Cordero» nada se nos dice de la naturaleza. Si lo comparamos con el tratamiento de «Pastor», veremos la diferencia. Fray Luis se dio cuenta de ello, y aun habiendo publicado este último nombre en la segunda edición, juntamente con el libro III, su composición se halla dentro del más sentido sentimiento de la naturaleza. Al tener que situarlo en la mañana del primer día es arrastrado por la luz y las perspectivas lejanas.

El lector atento del tercer libro advierte la falta del enraizamiento en la naturaleza propio de los primeros. Falta aquí el lenguaje referencial de la naturaleza que nos hacía estar en un permanente sabor naturalista. La obra literaria se convierte en el libro III en doctrinal, siempre dentro de la riqueza del

15. Op. cit. 710. Hijo de Dios.

16. Op. cit. 711. Hijo. 
lenguaje y la arquitectura de contenido que caracteriza a Fray Luis. Al debilitarse las relaciones entre la composición y el paisaje, la serie de los diálogos se abre completamente y da cabida a cuantos elementos se desee. Continúa el esqueleto doctrinal, pero se pierde la unidad de composición. El paisaje facilita la arquitectura de la obra. Si la estructura interna que sostiene este edificio de Los Nombres de Cristo es el tema de Cristo, la estructura externa y formal es el contorno y el motivo de la naturaleza que acogen sobre sí la variedad del tratamiento temático. En la secuencia de Los Nombres lo único que permanece es el tema y el paisaje de La Flecha o del soto. Si suprimimos el paisaje toda la obra se resentirá de falta de cohesión formal. El paisaje de Los Nombres de Cristo tiene la función de vincular unas partes a otras. De aquí esa impresión de totalidad que nos da la lectura de esta obra, en contraste con los libros doctrinales de la época cuya composición está basada únicamente sobre la coherencia del contenido.

\section{Resumiendo:}

Hemos intentado hacer patente la función unitaria que tiene el paisaje en Los Nombres y, al mismo tiempo, destacar los motivos de creación que la naturaleza ofrece al escritor.

Para descubrir toda la trascendencia que la naturaleza tiene en Los Nombres de Cristo, tenemos que averiguar la función que desempeña dentro de la estructura literaria. Para ello hay que distinguir previamente entre la naturaleza como lenguaje referencial que apunta al tema, a Cristo, y como referente, en sí misma.

La forma dialogada exige un elemento que dé unidad al conjunto, y es la naturaleza quien cierra la composición y da movilidad a las ideas religiosas. Fray Luis vincula el contenido de Los Nombres al tiempo y al paisaje, especialmente en los dos primeros libros. Hemos visto también que a una perspectiva que va de la horizontalidad a la verticalidad corresponde otra del mismo signo en el tratamiento estético del contenido.

Las más inspiradas poesías de Fray Luis se refieren, en alguna manera, a la naturaleza o a preocupaciones cosmológicas. Esto mismo es patente en la significación que adquiere el tema de la poesía al exponerlo en uno de los nombre más naturalistas, el de «Monte». La contemplación de la noche estrellada trae de la mano la idea de la paz como armonía entre los hombres.

En el libro III apenas hay paisaje. Eso sí: nos ofrece un mayor movimiento y dramatismo. Son ejemplos la introducción y el episodio de la avecica. De aquí la impresión que nos produce de una unidad menos fuerte.

El paisaje de Los Nombres de Cristo es el elemento que da unidad a la estructura literaria. El poeta relaciona con él el tratamiento del contenido. De 
aquí parte, a nuestro modo de ver, la función tan destacada que tiene en esta obra.

\section{Plano del símbolo: la naturaleza y el tema}

Para delimitar la función de la naturaleza respecto al tema general de la obra es conveniente atender a las intenciones que el autor expresa claramente en la dedicatoria del libro I. En ella Fray Luis se duele de que la lectura de los libros sagrados, que fue en otro tiempo pasto diario del cristiano, se hubiera convertido en algo pernicioso. Recuérdese que ya el Concilio de Tarragona había prohibido tener y leer la Biblia en lengua vulgar. En tiempos de Enrique IV se había prohibido traducirla en romance. En el catálogo de libros prohibidos de 1559 hay una prohibición formal también. En 1564 lo confirma el índice del Concilio de Trento. Era necesario oponerse a la costumbre de los judíos que vulgarizaban caprichosamente la escritura; posteriormente fue una reacción contra los excesos de la Reforma ${ }^{17}$.

Al parecer de Fray Luis, las causas de que lo bueno se haya convertido en algo pernicioso son dos: «la ignorancia y soberbia, y más soberbia que ignorancia; en los cuales males ha venido a dar poco a poco el pueblo cristiano, decayendo de su primera virtud $»{ }^{18}$. La ignorancia ha estado de parte de quienes debían conocer las ciencias sagradas, y la soberbia de parte de éstos y del cristiano común. Es necesario hacer énfasis en la convicción de Fray Luis de la soberbia de los maestros que no aprecian en su justo valor el conocimiento de las Escrituras. A ello hay que añadir que uno de los recursos estéticos más frecuentes en nuestro poeta para resaltar una idea es el del contraste.

Con el vulgo lo que ha ocurrido es que, al no disponer de libros santos, las gentes se han dedicado a leer libros vanos y dañosos. De estos libros nace la perdición de las buenas costumbres. Las doncellas los llevan en la faltriquera y conversan con ellos a todas horas; y los padres no se recatan de ello; «por donde las más de las veces les sale vano y sin fruto todo el demás recato que tienen» ${ }^{19}$. Como nota el P. Félix García, estos libros debían de ser los de caballerías y de poesía amorosa, tan en boga en aquel momento.

Fray Luis piensa que todos los buenos ingenios deben escribir que sean allegados a las Sagradas Escritura para que suplan por ellas la lectura del pueblo, «y juntamente les quiten de las manos, sucediendo en su lugar de ellos los libros dañosos y de vanidad ${ }^{20}$. Por tanto, es clara la conclusión: es nece-

17. Op. cit. 386 , nota 8 , del P. Félix García.

18. Op. cit. 387. Dedicatoria libro $I$.

19. Op. cit. 389. Dedicatoria libro I

20. Op. cit. 389. Ib. 
sario usar todo tipo de ardides para contrarrestar el influjo de las lecturas perniciosas.

Hay, pues, dos motivos que mueven a Fray Luis a escribir Los Nombres de Cristo: uno es la proliferación de libros profanos, que hemos de centrar en las novelas de caballerías y en la poesía amorosa, ya que el escritor era entusiasta de lo pastoril; otro es la soberbia de quienes podían escribir obras de devoción en lengua romance y que no lo hacen, o por menospreciar esta lengua o por menospreciar el estudio de las Sagradas Escrituras. El que después de estas ideas comience Los Nombres con una magnífica descripción de La Flecha, tan naturalista y tan concreta, y tan nueva en los libros de tema religioso, ha de tener algún sentido. Y es que el paisaje de La Flecha es de una sencillez y atractivo sin par. Acostumbrados a la dureza arrogante del silogismo escolástico los lectores de entonces tenían que recibir estos párrafos como un chorro de agua bienamada:

«Es la huerta grande, y estaba entonces bien poblada de árboles, aunque puestos sin orden; mas eso mismo hacía deleite a la vista, y, sobre todo, la hora y la sazón. Pues entrados en ella, primero, y por un espacio pequeño, se anduvieron paseando y gozando del frescor; y después se sentaron juntos a la sombra de unas parras y junto a la corriente de una pequeña fuente, en ciertos asientos. Nace la fuente de la cuesta que tiene la casa a las espaldas, y entraba en la huerta por aquella parte, y corriendo y estropezando, parecia reírse. Tenian también delante de los ojos y cerca de ellos una alta y hermosa alameda. Y más adelante, y no muy lejos, se veía el río Tormes, que aún en aquel tiempo, hinchiendo bien sus riberas, iba torciendo el paso por aquella vega. El día era sosegado y purísimo, y la hora muy fresca» ${ }^{21}$.

En primer lugar, ya el hecho de escribir en romance, supone una defensa de la humildad y la verdad que estaba dentro de la actitud espiritual de Fray Luis. Pero hay más: todo el sentimiento de la naturaleza que aquí respiramos es una invitación a la sencillez. Lo mismo ocurre con el mundo natural como continua metáfora de Cristo. Toda la obra, al hallarse en este ambiente naturalista, se encuentra arropada de un sentido de humildad que el escritor echa de menos en los sabios que debían escribir sobre las Escrituras. Aquí viene también algo que estudiaremos más adelante: el sentido de alabanza de aldea permanente en nuestro poeta. Es una idea constante de su pensamiento: la naturaleza es lo sencillo y posee los más auténticos valores de la verdad: «...mas, al revés, la vida del campo y el labrar uno sus heredades es una como escuela de inocencia y verdad; porque cada uno aprende de aquellos con quien negocia y conversa» ${ }^{22}$. Después de la dolorida dedicatoria a Portocarrero, este pórtico de la descripción de La Flecha significa la entrada de aire fresco en la literatura y en los tratados de vida religiosa.

21. Op. cit. 392. Introducción libro I.

22. Ib. 253. La perfecta casada, 2. 


\section{A. Los Nombres de Cristo, libro antilibros}

Fray Luis necesita contrarrestar el influjo de los libros de caballerías y de poesía amorosa ${ }^{23}$. Una de las características de estas obras es la aventura continua en los más diversos parajes. La imaginación del lector se encuentra en todo momento en unos lugares fantásticos. Pero Cristo es un personaje real. Por otra parte, el afán de descubrimientos geográficos y el deseo de un conocimiento más ajustado del contorno del hombre hacía que el mundo real pudiera llamar a la imaginación tanto como el ideal. Fray Luis hace lo mismo que Cervantes: toma un método al que le da vida y realidad. Cuando Cervantes hace cabalgar a Don Quijote por los caminos de España, se ha apropiado del sistema de los libros de caballerías, pero, al mismo tiempo, los ha desmitificado. Fray Luis se encuentra preocupado por la contextura formal de los libros que ha de combatir. En ellos hay un paisaje. Fray Luis observa también que las églogas y las novelas pastoriles se desarrollan en unos lugares determinados: la acción de La Diana, de Montemayor, transcurre por las riberas del río Esla, amables hoy tanto como ayer. En Garcilaso podemos reconocer al río Tajo. Es abundante la literatura en castellano sobre el tema de los ríos. También Salamanca tiene un río, el Tormes, y un paisaje concreto, La Flecha. El acierto de Fray Luis es situar Lo Nombres en un lugar concreto. Al mismo tiempo que se adueña de la estética del momento, logra encadenar la imaginación ardiente del hispánico. Esto tenía que se una llamada constante para los lectores, especialmente los salmantinos que conocen La Flecha. Además, las verdades de la religión cristiana no deben confundirse con las aventuras caballerescas o las andanzas pastoriles. Por ello, el paisaje real sirve para reforzar la realidad de aquello de que se habla. La llamada continua al lugar concreto en que se desarrollan Los Nombres potencia, formalmente, la realidad de Cristo y su presencia en el mundo, que es lo que el escritor quiere mostrar. Y que Fray Luis se apropia del método de los escritores profanos del Renacimiento nos lo indica también el que cada libro termine con la traducción de un salmo. La Biblia era para él la única fuente verdadera. Él sabe que abundan los versos en la literatura pastoril y que las gentes cantan versos profanos en la calle, en las plazas, en todo lugar. Por eso, en el breve prólogo a sus traducciones sagradas afirma que la poesía bíblica debería ser la única digna de ser cantada ${ }^{24}$.

23. Dice Fray Luis en La perfecta casada: «...y que las excusen (sus maridos) y libren de leer en los libros de caballerías, y de traer el soneto y la canción en el seno, y del billete y del donaire...» Op. cit. 266.

24. "Y plugiese a Dios que reinase esta sola poesía en nuestros oídos, y que sólo este cantar nos fuese dulce, y que en las calles y en las plazas, de noche, no sonasen otros cantares, y que en éstos soltasen la lengua el niño, y la doncella recogida se solazase con esto, y el oficial que trabaja aliviase su trabajo aquí. Mas ha llegado la perdición del ḥombre cristiano a tanta desvergüenza y soltura, que hacemos música de nuestros vicios, y no contentos con lo secreto de ellos, cantamos con voces alegres nuestra confusión».

Op. cit. 1635. Intr. Traducciones Sagradas. 
Estos salmos colocados al final de cada libro muestran el deseo de substituir lo profano por lo religioso. De nuevo, Fray Luis toma el método profano y lo llena de contenido religioso, que es lo que a él le interesa. Otros autores de la época intentaron hacer lo mismo, sólo que de una manera mucho menos sutil: traduciendo los versos profanos a los divino. La actitud de nuestro poeta es más inteligente. A ella tendremos que referirnos para explicar muchos pasajes en su significación completa. En ningún momento debemos perder de vista esta intención anti-libros profanos que tiene el autor y que se refleja en la forma por una actitud completamente opuesta: la de apoderarse de la estética del libro que se trata de combatir.

\section{B. Deleitar aprovechando}

Junto a la idea de enmarcar geográficamente Los Nombres, hay también una voluntad de amenidad. Si los libros profanos están siempre en la faltriquera de las doncellas, ha de ser porque les gustan, porque son amenos. El problema que se le plantea a Fray Luis es difícil: ¿Cómo hacer que una obra religiosa tenga el atractivo y el impacto de otra de caballerías o amoríos? Al escribir en lengua romance ha dado ya un gran paso en este sentido. Era difícil encontrar una acción narrativa para un asunto doctrinal. Por otra parte la teología densa y extensa de Los Nombres no cabría en una obra dramática. Fray Luis recurre a una forma clásica que está de moda en el Renacimiento: el diálogo. He aquí otro de los aciertos del poeta. De las posibilidades que tenía, ha sido certero en la elección: la forma dialogada tenía una tradición de prestigio clásico y era utilizada por los grandes escritores europeos. En ella se habían tratado temas de pasatiempo, como en Boccaccio, o de lengua, como en el Bembo o J. Valdés, o de religión y moral, como en Erasmo o Alfonso Valdés, o de amor neoplatónico, al estilo de León Hebreo. El diálogo da variedad y movimiento a las ideas, al mismo tiempo que hace posible una dialéctica de las opiniones. Junto a la lengua romance y la forma dialogada el paisaje es el tercer elemento que le sirve a Fray Luis para dar amenidad a su obra. En el Renacimiento surge de nuevo la máxima horaciana de deleitar apro. vechando. Fray Luis persigue deleitar al lector para enseñarle las verdades de la religión. Se ha dado cuenta de la importancia que ha tomado la naturaleza durante el Renacimiento y cómo se comienza a mirar el campo como lugar de recreo. Se construyen las más bellas ciudades de la historia, pero también entra el campo en los jardines. Al unir el tema de Cristo y la naturaleza, el autor trae amenidad y comprensión. El paisaje de La Flecha es un halago a los sentidos. Al mismo tiempo que presentar este paisaje, Fray Luis hará que toda la obra respire un cierto aire naturalista a base de prodigar la metáfora desde un lenguaje referencial. Él mismo defendió el simbolismo religioso. La naturaleza, sin marco, ayuda a hacer agradable y asequible a la explicación de los misterios de Cristo. La naturaleza y el campo son la base de un lenguaje refe- 
rencial para las ideas religiosas. Explicar la Teología bajo las metáforas de «Pimpollo», «Pastor», «Monte», «Camino» o «Príncipe de la paz» tenía que ser mucho más comprensible y ameno que las lecciones de cátedra. Incluso el lector de nuestros días podrá olvidar los conceptos teológicos de esta obra, pero no el paisaje y el aroma en que se desarrolla la figura de Cristo y su significación religiosa. La naturaleza, pues, sirve aquí para enseñar, como elemento referencial, y sirve para agradar, como referente, en sí misma considerada, en la delimitación de las riberas del Tormes. Realmente es una tarea difícil combatir una novela rosa con un libro de religión. Se necesitan muchos ingenios, como dice Fray Luis, e ingenio, como se nos ocurre a nosotros. El poeta pone a este servicio lo mejor de sí mismo. Y su ingenio era grande. De ahí nuestra búsqueda del significado de los elementos de creación luisianos.

\section{Lo real en el paisaje y en el tema}

La naturaleza concreta del paisaje de La Flecha desempeña, además, otra función más sutil. Hasta el siglo XVI la naturaleza había estado un tanto idealizada. Los mismos paisajes pastoriles son algo estilizado. Resultan tan irreales como sus personajes y sus amores. Bastarán unos lugares concretos y unos nombres del pueblo llano que se alejen de los de aquellas novelas para dar veracidad a la creación literaria y hacer que los personajes se confundan con la realidad. Y esto es lo que hace aquí el paisaje de La Flecha. Su realidad atrae la realidad de Cristo, y todas las verdades religiosas y abstractas quedan matizadas de un tono de verdad tangible. Incidir continuamente sobre lo real es una de las características de Fray Luis. Lo vemos en sus preferencias por el dato existencial, como ocurre en las observaciones del Cantar o de La perfecta casada o en las angustiadas consideraciones del Comentario al Libro de Job. Era hombre de grandes vuelos metafísicos, pero también de realidades tangibles. Esta misma idea de centrar la teología en Cristo, es decir, en el Dios vivo, nos da su interés permanente por lo tangible. Cuando Fray Luis se defiende en el proceso inquisitorial, no se anda por las ramas, y a las acusaciones anónimas da una respuesta concreta, citando los nombres de los acusadores. Mientras está en la cárcel indica el cajón de la mesa y el formato de los libros que ha pedido. El sentido realista del paisaje de La Flecha se pasa a la naturaleza toda de la obra y, mediante ella, a Cristo, de tal forma que, cuando vive en los campos Cristo, el lector funde los campos idealizados de la metáfora con las riberas y las cuestas y las lejanías que se contemplan desde el Tormes. Como en la novela de caballerías la irrealidad del paisaje tiñe de más irrealidad el conjunto, aquí la realidad del paisaje infunde realidad más tangible a las explicaciones teológicas. De esta forma todo contribuye a traer a Cristo a nuestro mundo. Y que esto es así lo vienen a corroborar las alusiones que hace Marcelo al paisaje inmediato, cuando indica el camino de la Corte, o escribe 
en el suelo o señala a los montes lejanos. De aquí procede también la voluntad de abrir y cerrar cada libro con referencias al paisaje. Al hacerlo así, todo lo que queda dentro, queda enmarcado en el realismo del paisaje que se describe.

Fray Luis no podía situar Los Nombres en un aula universitaria, como parece lo propio en un catedrático salmantino, porque eso hubiera sido alejar la doctrina de aquellos a quienes iba dirigida. El pueblo era agricultor y estaba acostumbrado a los aires libres del campo y conocía los lugares en que Marcelo, Juliano y Sabino se paseaban. Al llevar los diálogos a la huerta de La Flecha, Fray Luis sigue la misma inspiración que le llevó a escribirlos en romance: airear la teología. Comienza así el resurgir de una teología popular que culminará en el barroco, donde sale a la calle en los carros de los autos sacramentales. La naturaleza colabora a poner las verdades religiosas al nivel del pueblo. Unos diálogos en el claustro universitario o en la celda conventual hubieran producido la impresión de conservar el misterio cristiano en su reducto medieval. La metáfora naturaleza-Cristo llega a fundirse en la de paisaje-Cristo, donde el término real es más cercano y la metáfora más pura. El lector percibe más intensamente la realidad de Cristo.

\section{La naturaleza como signo de Cristo}

La naturaleza y el cosmos todo son en muchas de las páginas de los diálogos de Los Nombres signo de valores morales y religiosos, signo de Cristo. A Él tienden, como a un blanco, todas las cosas. Las descripciones naturalistas apuntan a sus mismas características en Cristo. El código es la relación que media entre la representación de la naturaleza y la representación del personaje de Cristo. Hay un proceso de lo más conocido a lo menos conocido. La naturaleza, que tiene un valor substantivo en sí misma, se vierte inmediatamente a valores religiosos. Siguiendo a Tzvetan Todorov podemos decir que «la relación entre la serie a traducir y la traducción se establece a través de una regla que podría llamarse de identificación por el predicado»" ${ }^{25}$. Si A es B y C es B, C/A.

Si los campos son escuela de verdad e inocencia, Cristo que también es verdad e inocencia puede decirse que vive en los campos. La vida pastoril e inocente y Cristo es inocente también; por tanto, puede decirse que Cristo es Pastor. Éste es el plano contínuo de transposición de términos en que se mueve la concepción luisiana de la naturaleza: ésta adquiere un connotación religiosa. En realidad, todo se resuelve en una gran metáfora donde la naturaleza es la frontera entre los hombres y Cristo, como el hilo conocido que nos ayuda a comprender lo desconocido. Fray Luis es consciente de este simbolis-

25. TzVetan TODOROV, Literatura y significación, Barcelona 1971, 182. 
mo religioso que ha tomado de la Biblia y que estaba ya en el ambiente espiritual de la Edad Media:

«Y particularmente en este misterio y promesa de Cristo, para asentársela en la memoria y en la afición, se la ofrece en los libros divinos casi siempre vestida con una de dos figuras. Porque toca a la gracia, que desciende de Cristo en las almas, y a lo que en ellas fructifica esta gracia, dícesele debajo de las semejanzas tomadas de la cultura del campo y de la naturaleza de él. Y, como vimos esta mañana, para figurar aqueste negocio, hace sus cielos y su tierra, y sus nubes y lluvia, y sus montes y valles, y nombra trigo y vides y olivas con grande propiedad y hermosura» ${ }^{26}$.

Reconocemos aquí el mecanismo de la metáfora, donde se pasa de un término conocido a otro desconocido e incluso a su substitución. La naturaleza hace referencia a Cristo y el entendimiento establece el código entre lo abstracto y lo concreto, lo visible y lo invisible. Cristo llega a ser para el lector tan presente como los campos que rodean la ciudad. Si a esto unimos la función que desempeña el paisaje en la estructura de la obra y en la comunicación con los personajes, tendremos una visión de Cristo mucho más vívida y palpitante. A este propósito, nos ayuda un párrafo de Todorov en la obra citada: «Las figuras repertoriadas por la retórica son otros tantos casos particulares de una regla abstracta que rige el nacimiento de la significación en toda actividad humana, desde el sueño a la magia. La existencia de un predicado común hace motivado el signo; lo arbitrario del signo que caracteriza a la lengua cotidiana parece ser un caso excepcional» ${ }^{27}$. El signo es aquí motivado ya que la interpretación de la naturaleza en términos religiosos estaba respaldada por la Biblia. Pero, mientras la naturaleza bíblica es puramente simbólica, aquí se trata de una naturaleza referencial que también tiene una realidad substantiva: hay árboles, montes, ríos y elementos reales. Esta naturaleza, un tanto idealizada y sin marco, al ponerse en contacto con la concreta del paisaje de La Flecha, se ve enriquecida de un superior realismo. Ello produce un efecto de ensoñación, que es típico de la obra de Fray Luis, y que consiste en que lo real y concreto se funde a lo más general para darle más consistencia y vida. Lo religioso y lo natural, el mundo de Dios y el mundo del hombre quedan así enlazados: "Y lo que hizo en aquesto visible, eso mismo ha obrado en lo nuevo invisible, procediendo en ambas formas por unas mismas pisadas» ${ }^{28}$.

- En Los Nombres de Cristo hay imágenes bellísimas de tipo religioso sobre un simbolismo de la naturaleza. Así, «por ella (la lluvia de la gracia) los yermos desiertos se vistieron de religiosas hayas y cedros» ${ }^{29}$. Es un acierto poéti-

26. Op. cit. 531. Brazo.

27. T. TODOROV, op. cit. 182-183.

28. Fray Luis. Op. cit. 504. Padre del Siglo Futuro.

29. Ib. 506. ib. 
co comparar las comunidades de monjes del desierto a religiosas hayas y cedros. Fray Luis busca intencionadamente la confusión entre la naturaleza exterior y Cristo; con ello consigue hacerle más cercano. Como vemos en «Faces de Dios», Cristo es la imagen de Dios y el mundo es imagen de Cristo. Desde luego no son lo mismo, aunque la metáfora los acerque. Fray Luis queda a salvo de todo el espíritu panteísta del Renacimiento. Al poner a Cristo en medio rompe toda posible identidad entre el mundon y Dios. Entre ambos está Cristo, ser personal y tangible, que marca la frontera entre lo humano y lo divino.

\section{E. El sentido existencial de lo religioso.}

El libro primero resalta más el aspecto referencial de la naturaleza. Cuatro de los seis nombres se refieren a ella. Entran dentro del sentido bucólico que preside la estética renacentista. "Pimpollo» se refiere a Cristo como fruto de todas las cosas. Fray Luis se sitúa así al lado de la corriente del pensamiento agustiniano que concibe toda la creación en función de Cristo. Esta concepción distancia a Fray Luis tanto del panteísmo renacentista como de la frialdad en que había situado el mundo parte de la teología y la filosofía tradicionales. Fray Luis afirma, desde un principio, el enraizamiento religioso del universo. Lo interesante para nosotros es advertir que esa vinculación de Cristo y el mundo se realiza en términos de belleza y de los elementos naturales que el escritor tiene delante. Es una llamada a la realidad y a hacer de lo religioso algo que se entrañe en la existencia del hombre. El llamamiento luisiano a la belleza y verdad del mundo natural es un continuo aldabonazo a integrar la religión en el medio en que vivimos y a vincular nuestro quehacer diario al fenómeno religioso. Ello es tan natural al hombre como el aire que respiramos porque éste, el aire, es ya religioso. El hombre ha roto la maravilla primera; por eso, volver a la naturaleza es volver al principio de las cosas, es decir a Dios. Por las riberas del Tormes hay una epifanía de Cristo en pleno siglo XVI:

«Así como el árbol se ordena para el fruto que de él sale «así por la misma manera, estos cielos extendidos que vemos, y las estrellas que.en ellos dan resplandor, y entre todas ellas esta fuente de claridad y de luz que todo lo alumbra, redonda y bellísima; la tierra pintada con flores y las aguas pobladas de peces; los animales y los hombres, y este universo todo, cuan grande y cuan hermoso es. Lo hizo Dios para fin de hacer hombre a su Hijo y para producir a luz este único y divino fruto que es Cristo, que con verdad le podemos llamar el parto común y general de todas las cosas» ${ }^{30}$.

30. Op. cit. 414-415. Pimpollo. 
Obsérvese cómo el deíctico «estos» da cercanía y existencialidad a los elementos de la naturaleza y cómo hay un interés por referirse al contorno inmediato más que al mundo en general. Son las cosas que los tres frailes tienen delante: el ancho cielo de Salamanca, el sol de junio, las flores que todavía pueblan la ribera del Tormes y las aguas llenas de peces juguetones. En la pluma de nuestro poeta sentimos que el universo`entero queda religado a una vida cristiana porque «Cristo, para cuyo nacimiento crió primero Dios las raíces firmes y hondas de los elementos, y levantó sobre ellas después esta grandeza del mundo con tanta variedad, como si dijésemos, de ramas y hojas, lo contiene todo en sí, y lo abarca y se resume en Él..." ${ }^{31}$.

Una de las características del sentimiento luisiano de la naturaleza es este sentido religioso de las cosas. Es patrimonio de todos los grandes poetas que han sabido sentir la realidad exterior. Emerson es el ejemplo del poeta que lleva su entusiasmo hasta un panteísmo místico. Fray Luis trata de acercar lo divino a lo humano. En las poesías en que prevalece la perspectiva filosófica, ocurre una tensión de signo contrario. Lo que trata entonces el espíritu esencialista del poeta es de elevar las cosas al plano de las esencias. Hay un trasiego continuo entre la perspectiva existencial y la esencial. La primera domina en el plano simbólico-religioso; la segunda en el plano de la especulación metafísica. En las poesías Fray Luis está profundamente preocupado por el sentido del universo. Cuando filosofa, la angustia y el misterio de lo desconocido arrancan de él los más hondos sentimientos de nostalgia; pero ya desde el principio de Los Nombres el poeta nos trae la interpretación religiosa de las cosas del mundo. Es oficio de filósofo y poeta el que ejerce Fray Luis al dar sentido a lo que le rodea. En Los Nombres encuentra que la realidad auténtica del mundo es de orden religioso. Es la misma convicción a la que llegará al final de su especulación filosófica y estética por el campo de la intuición poética! Para éi la venida de Cristo está precedida por la venida del mundo, con lo que, en cierta manera, se condicionan el uno al otro. En cualquier caso, una savia cristiana da vida al mundo. Lo que importa es destacarla al máximo porque ello significa hacer religioso el contorno en el que vive el hombre. De esta forma nos sentiremos influidos por una nueva vida al respirar el aire de la mañana. Todo el énfasis de nuestro poeta está en religar al hombre a Cristo. La naturaleza le ofrece una ayuda formidable. Así nuestra existencia es religiosa, se desarrolla en un contorno religioso y tiene por principio a Cristo que es también fruto de todo lo existente.

\section{F. Lo religioso, el bucolismo y el sentimiento cósmico}

Dentro del plano simbólico se desarrolla el nombre de «Camino». Fray Luis expone primero las características de lo que es un camino para aplicarlas

31. Op. cit. $415 . I b$. 
después a Cristo: al hacerlo es cuando señala Marcelo el camino que va desde Salamanca a la Corte. Con ello se consigue que las condiciones generales de lo que es un camino se concreten en uno determinado. Después dirá que Cristo es camino, senda, grada, calzada y sendero.

Entre el nombre de "Camino» y "Monte» encontramos el de «Pastor» que es uno de los más bellos de toda la obra y más lleno de sabor naturalista y bucólico. El esquema es el mismo que en los demás nombres: primero propone las condiciones de un pastor y después las aplica a Cristo. Hay verdadero mimo en el tratamiento de este nombre. Es grande en el Cristianismo la tradición de la metáfora del Pastor. Fue una de las definiciones que dio Cristo de sí mismo. A esto hay que añadir la vuelta a la naturaleza que se produce en el Renacimiento y la espontaneidad que supone lo pastoril. El poeta preferido de nuestro escritor era Virgilio y debía de pesar en él su estética. Así lo afirma Sabino. Se refiere a la vida pastoril:

«Cuando ninguno la loara - dijo Sabino-, bạsta para quedar muy loada lo que dice de ella el poeta latino, que en todo lo que dijo venció a los demás, y en aquello parece que vence a sí mismo; tanto son escogidos y elegantes los versos con que lo dice» ${ }^{32}$.

En la obra de Fray Luis Virgilio es siempre el Poeta y Horacio el Lírico. No hay duda sobre sus preferencias. Marcelo considera lo que pertenece al oficio de pastor y lo que pertenece a su persona. La vida del pastor es inocente y sosegada; el pastor es muy dispuesto al bien obrar; su ejercicio es gobernar dando pasto. Después aplica esto a Cristo que es buen Pastor. Es ya el plano de la metáfora y el símbolo:

«Vive en los campos Cristo, y goza del cielo libre, y ama la soledad y el sosiego; y en el silencio de todo aquello que pone en alboroto la vida, tiene puesto Él su deleite. Porque, así como lo que se comprende en el campo es lo más puro de lo invisible, y es lo sencillo y como el original de todo lo que de ello se compone y se mezcla, así aquella región de vida adonde vive aqueste nuestro glorioso bien, es la pura verdad y la sencillez de la luz de Dios, y el original expreso de todo lo que tiene ser, y las raíces firmes de donde nacen y adonde estriban todas las criaturas» ${ }^{33}$.

Marcelo sigue describiendo la vida del campo con expresiones muy semejantes a las de la oda «A la vida del cielo» que se halla al final de la especulación metafísica y estética de la creación poética luisiana y donde los elementos de la naturaleza representan un bucolismo a lo divino:

"Y si lo habemos de decir así, aquéllos son los elementos puros y los campos de flor eterna vestidos, y los mineros de las aguas vivas, y los montes verdaderamente preñados de mil bienes altísimos, y los sombríos y repuestos valles, $\mathrm{y}$

32. Op. cit. 445. Pastor.

33. Ib. 447. Ib. 
los bosques de la frescura, adonde, exentos de toda injuria, gloriosamente florecen la hava y la oliva y el lináloc, con todos los demás árboles del incicnso, en que reposan ejércitos de aves en gloria y en música dulcísima, que jamás ensordece»" ${ }^{34}$.

Aquí son claros los acentos místicos. La metáfora llega, no sólo a Cristo, $\operatorname{sino}$ a las moradas eternas. Fray Luis acumula en la descripción de la vida del cielo todo el bien que encuentra en la tierra. I.o interesante es notar cómo todo el gozo procede de elementos de la naturaleza. Se produce así una especie de bucolismo a lo divino. Esta forma de ver la naturaleza es tanto el producto de un fundamento teológico como de una posición estética. La metáfora es atrevida. La vida eterna se describe como un gozo al aire libre, entre los árboles y el cantar de las aves. Vemos también algo que es preocupación constante de su vida: el sentimiento de nostalgia por lo eterno: el énfasis en la belleza que no muere.

No es una casualidad que Fray Luis situara l.os Nombres en La Flecha. Ahora comprendemos por qué las aulas estaban reñidas con estos diálogos. Porque la vida cristiana se vincula al campo hasta tal punto que el mismo Cristo vive en ellos. Comprendemos cómo la naturaleza es la estructura subyacente que mantiene la unidad de la obra. La vista de los campos está recordando continuamente al lector la verdadera vida. Las expresiones de la vida pastoril y campestre son tan entusiastas y genuinas que llegamos a pensar si la vida del campo no será para Fray Luis lo mismo que vida cristiana. La naturaleza presta al poeta el lenguaje necesario para hablar de Cristo. Esto queda muy alejado de las discusiones escolásticas del aula universitaria. En Los Nombres vemos a un Fray Luis plenamente religioso. Hay metáforas bellísimas que recuerdan a los mejores sonetos religiosos del barroco:

«Madruga (Cristo), durmiendo nosotros descuidados del peligro que nos amenaza. Madruga, digo, antes que amanezca se levanta; o, por decir verdad, no duerme ni reposa, sino, asido siempre a la aldaba de nuestro corazón, de continuo y a todas horas le hiere»" ${ }^{34}$.

Según esto la naturaleza es una llamada continua a la vida religiosa. Y es lógico: si Cristo es el fruto del mundo, la tierra en que vivimos ha de ser buena. Ésta es una de las ideas claves de esta obra. La fauna y la flora de nuestro planeta ha de colaborar en la religación del hombre a lo religioso. Rimaba esta idea con la importancia que había tomado la vida del campo en el Renacimiento.

«Príncipe de la paz» es el otro nombre donde prevalece el fervor naturalista de Fray Luis. Cristo es la paz, y para explicarlo el poeta acude a la visión de la noche estrellada que los tres personajes tienen delante. La armonía de los astros es signo de la paz en la vida religiosa y moral. Un vago sentimiento cós-

34. Op. cit. 447. Pastor.

35. Op. cit. 449. Pastor. 
mico invade el espíritu de Marcelo ante la visión de la noche estrellada que recuerda los ecos de La Noche serena ${ }^{36}$.

El bucolismo de las horas de la luz del día se ha tornado en una emoción íntima ante la vista del movimiento de los astros. Pero el poeta también aprovecha los elementos que el mundo exterior le ofrece. Si leemos atentamente el comienzo del párrafo citado nos damos cuenta de cuál ha sido el principio estético seguido por Fray Luis para la explicación de la verdad cristiana. No es que la razón no pueda dar argumentos y demostraciones. Lo que el poeta hace es valerse de la intuición y de las cosas sensibles que le rodean. Al asombro de Fray Luis ante las maravillas del universo hay que añadir su deseo de presentar la teología de un modo asequible a todas las gentes. Nada mejor que la vista de la naturaleza y el asombro ante los cielos que, al mismo tiempo que era perceptible por todos, entraba dentro de la estética y las investigaciones científicas del Renacimiento.

\section{En resumen:}

Hemos visto que Fray Luis tiene dos motivos fundamentales para escribir Los Nombres de Cristo: la proliferación de los libros profanos y la soberbia de quienes menosprecian el estudio de la Sagrada Escritura. Para contrarrestar el influjo de los libros profanos el poeta se adueña de su método estético. De ahí que, frente al paisaje irreal de los libros de caballerías tengamos aquí uno real, y frente a las canciones amorosas Sabino recibe traducciones de salmos al final de cada libro. De lo pastoril toma el sentido amable de la naturaleza.

El paisaje de La Flecha, con su desnudez y encanto, es una llamada a la sencillez y a la verdad. También ayuda al poeta a encadenar la imaginación del lector y centrarla en la persona de Cristo.

Fray Luis es consciente de la máxima horaciana de deleitar aprovechando. La naturaleza colabora en la enseñanza de los misterios de la religión, al mismo tiempo que la hace más agradable. El paisaje de La Flecha desempeña otra función respecto del tema: la de hacer que, al contacto de su realidad tangible y conocida, la naturaleza en general y el personaje de Cristo, que vive en los campos, se vean también más vivos y reales.

En el aspecto referencial la naturaleza es signo de Cristo y adquiere una connotación religiosa permanente. Lo que pretende Fray Luis es hacer de la vida religiosa un modo de existencia connatural al hombre mediante el enraizamiento religioso en Cristo de su contorno. La vida del campo es inocencia y verdad: de ahí ese bucolismo a lo divino que encontramos en esta obra.

Todo ello viene a mostrarnos la relación íntima que se da entre el paisaje y la naturaleza de Los Nombres con el tema fundamental, que es Cristo.

36. Op. cit. 585. Príncipe de la paz. 


\section{Plano de la comunicación: la naturaleza y los personajes}

En el plano de la comunicación el desarrollo del tema de la naturaleza en Los Nombres de Cristo tiene una honda raigambre renacentista. Consideraremos diversas perspectivas de este plano que es de lo más original de Fray Luis.

Ya desde un principio hemos visto cómo el escritor toma el diálogo como la forma de composición de Los Nombres. Éste sentido de conversación con las cosas presidirá todo el pensamiento luisiano e influirá en su acercamiento a la naturaleza. El plano de la comunicación se desarrolla en torno a los personajes que intervienen en la obra.

\section{A. El paisaje como invitación al diálogo}

En la introducción del libro I, después de la descripción de la huerta, es Sabino, el poeta, quien se siente llevado a conversar por el paisaje que tiene delante:

«Algunos hay a quien la vista del campo los enmudece; y debe de ser condición de espíritus de entendimiento profundo; mas yo, como los pájaros, en viendo lo verde, deseo o cantar o hablar» ${ }^{37}$.

Esta afirmación está en la misma base del auténtico sentimiento de la naturaleza. La belleza del campo y los fenómenos naturales modifican el espíritu del hombre y se apoderan de él. Sólo podía darse esta influencia en una estética renacentista, donde la naturaleza adquiere autonomía propia. Ella está frente al hombre; es algo distinto de él, hasta tal punto que puede alterar su estado de ánimo e impulsarle a la palabra. A su vez, la naturaleza se verá vestida con un ropaje humano. Interesa destacar que es el paisaje lo que va a motivar el diálogo entre los tres frailes. Un siglo antes habría sido imposible pensar que la naturaleza pudiera determinar el comienzo de una obra literaria. También anota aquí Sabino el sentimiento de fascinación que le produce la vista del campo. Es otra forma de comunicación típicamente renacentista. La fascinación supone una veneración. El desconcierto del hombre renacentista descubriendo los secretos y la belleza de su contorno es tal que el panteísmo es la salida lógica para muchos espíritus: el mundo es Dios. Marcelo abunda en el sentimiento de fascinación de Sabino, pero ahonda más en su significación al proponer el sentimiento de la naturaleza como una consecuencia del carácter alegre o melancólico ${ }^{38}$.

La actitud melancólica estaba de moda en el Renacimiento. Era muestra de un espíritu profundo y en comunicación con las cosas. Las damas y doncellas procuraban aparecer pálidas y demacradas para causar un impacto ma-

37. Op. cit. 393. Intr. libro I.

38. Op. cit. 393. Intr. libro I. 
yor en su medio. Más adelante estudiaremon este tema en relación con Fray l.uis. Por ahora nos hasta decir que esa melancolia ante el paisaje es un anuncio de romanticismo en pleno Siglo de Oro. Juliano, el tereer interlocutor, responde que él no está siempre del mismo humor. pero pide a Sabino un lema para conversar porque a cl también le invita a ello la vista de La Flecha:

"No soy siempre de uno mismo - respondió Juliano-, porcute ahora al humor de Sabino me inclino más. Y' pues de no puede razonar consigo mismo mirando la helleza del campo y la grandera del cielo, hien será que nos diega su gusto acerea de lo que podremos hablar" "".

Desde el comienzo se establecen los dos motivon estélicos nalurales que han de predominar en la obra: el paisaje y la vista del ciclo. A la afirmación del escritor de que "el día era soscgado y purisimo y la hora muv fresca" corresponde el deseo de Sabino de hablar de ('risto pues es uel dia santo y la sazón tan a propósito de plálicas semejantes..." De nuevo vemos el tema y el contorno exterior puestos en relación. El paisaje invita al diálogo porquic el mismo es comunicación que se pasa a los personajes.

Es curioso observar el alcance que Fray I uis concede al diálogo. Desde la dedicatoria del libro I concibe el libro profano que leen las doncellas como alguien "que conversa con el que le lee a lodas horas y a todos tiempos»" ¿N $\mathrm{No}$ será la forma dialogada de Los Nombres una manera sutil de querer poner los temas religiosos en los bolsillos de las gentes? Porque en esta obra lodos los elementos acaban dialogando a su modo: los tres frailes, Cristo, el paisaje y el lector.

Ya hemos visto anteriormente cómo por medio de la metálora (risto es traído a los campos donde conversan los tres personajes. Con frecuencia Marcelo se dirije a Cristo directamente. El paisaje o algunos de sus elementos entran a formar parte del diálogo también. El final del primer libro es significativo en este sentido. El sol está en el cénit y lodo ces pura verticalidad. Marcelo puntualiza:

«...No parece jusıo, después de un semejanle fin, añadir más. Y pues Sabino ha rematado tan bien nuestra plática, y hemos ya platicado asaz y largamente, $y$ el sol parece que por oírnos, levanlado sobre nuestras cabezas, nos ofende ya, sirvamos a nuestra necesidad ahora reposando un poco; y a la tarde. caida la siesta de nuestro espacio, sin que la noche aunque sobrevenga lo estorbe, diremos lo que nos restan ${ }^{+1}$.

El sol entra a formar parte como un interlocutor más que, desde su verticalidad cenital, se acerca de puntillas para escuchar a los tres frailes.

39. Op. cit. 393. Intr. libro $I$.

40. Ih. 388. Dedicatoria libro I.

41. Op. cit. 509. Padre. 


\section{B. Sentimiento de la noche}

La comunicación con la naturaleza se acentúa al venir la noche. Al comienzo de Rey de Dios Marcelo nos dirá que está acostumbrado a hablar al oído de las estrellas con las que comunica sus preocupaciones. Herrera y Aldana participan también de este sentimiento de la noche. Ya las escenas de amor en el jardín de Melibea habían tenido lugar durante la noche. Es otro de los avances del Renacimiento sobre el romanticismo.

La armonía del universo que procede del amor y está en permanente conversación es una de las ideas más bellas de Fray Luis que él ha formado tomando la base de la estética platónica. Aquella angustia que le hacía a Marcelo pasarse las noches en vela hubo de buscar un conversador en la noche silenciosa. Las estrellas, en lo alto, eran la mansión de las ideas y las esencias a las que nuestro escritor perseguía. Por ello, Marcelo - que es el portador de las ideas de Fray Luis-, ha aprendido a sincerarse con ese maravilloso mundo titilante de luz:

«En confusión me pusiera, Sabino, lo que habéis dicho, si ya no estuviese usado a hablar en los oídos de las estrellas, con las cuales comunico mis cuidados y mis ansias las más de las noches; $\mathrm{y}$ tengo para mí que son sordas; $\mathrm{y}$ si no lo son y me oyen, estas razones de que ahora tratamos, no me pesará que las oigan, pues son suyas... Así que oiga en buena hora el cielo lo que nos vino del cielo y lo que el mismo cielo nos enseñó. Mas sospecho, Sabino, que según es baja mi voz, el ruido que en esta presa hace el agua cayendo, que crecerá con la noche, les hurtará de mis palabras las más» ${ }^{42}$.

Tenemos a la realidad y a la metáfora fundidas. Así se potencia la imagen. La presa del Tormes participa en la conversación como un elemento que puede impedir la comunicación con su ruido. Vemos que Fray Luis concibe la unidad del cosmos todo en términos de comunicación. Ante la influencia del mundo exterior el hombre se ve obligado a rimar su espíritu al compás de los fenómenos de la naturaleza. Ya indicamos cómo la escena del huerto de Melibea, en la Celestina, es un precedente de esta simpatía con la naturaleza.

El paisaje va calando cada vez más en los personajes de Los Nombres. Eso se muestra por esos momentos de silencio que se dan entre ellos, especialmente en Marcelo. Con frecuencia hay un vago sentimiento de plenitud que le hace detenerse en la conversación y ensimismarse por unos momentos. Durante los parlamentos nocturnos el paisaje va perdiendo objetividad para penetrar más en la interioridad de los personajes. Del mundo de las sensaciones que se dan a la luz del día se pasa a las emociones que se dan en la oscuridad de la noche. Crece la intimidad entre el hombre y la naturaleza. El paisaje se torna más opaco, hasta llegar a un subjetivismo que entraña la raíz del más auténtico sentimiento de la naturaleza. Al mismo tiempo, los temas se hacen

42. Op. cit. 547-48. Rey. 
más vaporosos y, mientras durante el día Marcelo acude a las sensaciones para situar la figura de Cristo, ahora acude al campo más hondo de las emociones. Los nombres de «Príncipe» y «Esposo», que se desarrollan durante la noche son los más intimistas de la obra.

Ya vimos que la perspectiva del soto, donde tienen lugar los diálogos nocturnos, es diferente de la de La Flecha. Si en el primer libro, por la mañana, el paisaje colabora con Cristo en la perfección del hombre, ahora el momento oscuro de la noche ha ganado a los personajes que son arrastrados por la emoción profunda de la noche serena. Vemos que la alegría de los primeros nombres ha cedido el paso a un tono de melancolía que se proyecta sobre un delicado estoicismo. Una lánguida nostalgia de Dios lo invade todo en la noche.

El paisaje del soto es mucho más intimista que el de la huerta. Por la mañana podían ver, desde las poyatas en que estaban sentados, una alta alameda y más adelante, el Tormes que iba torciendo su paso por la vega. Esta perspectiva de lejanía comunica gozo y expansión a los personajes. El escritor se siente influido por esta vista ancha y panorámica y le parece que la fuente de La Flecha retoza y salta y ríe. Estos espacios abiertos se comunican al corazón, y afloran a la pluma del escritor los temas más gráciles y bucólicos. Esta actitud de alegría exultante continúa durante toda la mañana hasta comunicarse al sol y a todo el contorno. La perspectiva cerrada del soto trae una emoción muy distinta. El lugar es pequeño y recogido; está bien poblado de árboles con mucha hoja. Pero, mientras en la huerta se podían contemplar un fondo amplio de aguas, alamedas y horizontes lejanos, en el soto lo que hay delante es la otra parte que forma un pequeño arroyo con el agua sobrante de la presa:

«Pues entrados en él Marcelo y sus compañeros, y metidos en lo más espeso de él y más guardado de los rayos del sol, junto a un álamo alto que estaba casi en el medio, teniéndole a las espaldas, y delante los ojos la otra parte del soto, en la sombra y sobre la yerba verde, y cuasi juntando al agua los pies se sentaron. Adonde diciendo entre sí del sol de aquel día, que aún se hacía sentir, y de la frescura de aquel lugar que era mucha, y alabando a Sabino su buen consejo, Sabino dijo así...» ${ }^{43}$.

En La Flecha el escritor describe lo que los frailes van viendo a medida que extienden la vista desde el lugar en que están sentados. En el soto han tenido que pasear para que nosotros sepamos qué hay en él. No hay lejanía ni más horizonte que el del cielo. Todo invita al recogimiento en el soto. Antes se habían sentado a la sombra de unas parras: horizontalidad arriba y abajo; ahora se sientan en el suelo, junto a un alto álamo: horizontalidad abajo y verticalidad arriba. La línea blanca del álamo señala a los tres frailes la dirección de su mirada. El espíritu se cierra sobre sí mismo. El soto es un rincón delicioso que obliga a mirar hacia arriba. Prepara a los interlocutores para un

43. Op. cit. 517. Intr. libro II. 
cambio de actitud. Hay un mayor quietismo que irá cayendo poco a poco hasta apoderarse de los personajes durante las horas de la noche en que el único elemento exterior que se les ofrece es la verticalidad absoluta del cielo estrellado y el fondo delicioso del agua del arroyo. Ya lo había presentido Sabino al comienzo de la tarde:

«Aquí Juliano, levantando los ojos, miró hacia el sol que ya se iba a poner, y dijo:

- Huyen las horas, y casi no las habemos sentido pasar, detenidos, Marcelo, con vuestras razones; más para decir lo demás que os placiere, no será menos conveniente la noche templada, que ha sido el día caluroso.

-Y más - dijo encontinente Sabino - que, como el sol se fuere a su oficio, vendrá luego en su lugar la luna, y el coro resplandeciente de las estrellas como ella, que, Marcelo, os harán mayor auditorio, y callando con la noche todo y hablando sólo vos, os escucharán atentísimas. Vos mirad no os halle desapercibido un auditorio tan grande» ${ }^{44}$.

La comparación de superioridad «mayor auditorio» supone la convicción de que el mundo de los astros es un personaje más del diálogo. De ahora en adelante Marcelo es quien se siente más identificado con la naturaleza. Sucede la melancolía de la noche unida al respeto y fidelidad a lo real: mientras la luz de la mañana hace cantar de gozo a Sabino, la profundidad de la noche es quien toca el espíritu de Marcelo.

\section{El silencio y el ser de las cosas}

Al comenzar el nombre «Príncipe de la paz» se van perdiendo las fronteras entre lo animado y lo inanimado. Marcelo tiene los ojos clavados en los cielos. El amor que rige la armonía de las estrellas tiene mucho del corazón humano porque allá en lo alto están «como hermanadas todas y como mirándose entre sí, y comunicándose sus luces las mayores con las menores se hace muestra de amor, y como en cierta manera se reverencian unas a otras, ý todas juntas templan a veces sus rayos y sus virtudes, reduciéndolas a una pacífica unidad de virtud, de partes y aspectos diferentes compuesta, universal y poderosa sobre toda manera» ${ }^{45}$. Es un sentimiento místico-estético de la unión del hombre y el universo. En la visión de la noche estrellada de nuestro poeta el hombre presta su corazón a los astros, pero, a su vez, recibe el influjo de sus luces:

«Porque, si estamos atentos a lo secreto que en nosotros pasa, veremos que este concierto y orden de las estrellas, mirándolo, pone en nuestras almas sosiego; y veremos que, con sólo tener los ojos enclavados en él con atención, sin sentir en qué manera, los deseos nuestros y las afecciones turbadas, que

44. Ib. 546. Brazo.

45. Op. cit. 585. Príncipe de la paz. 
confusamente movían ruido en nuestros pechos, de día, se van quietando poco a poco y como adormeciéndose se reposan... ${ }^{46}$.

Hay un trasvase de mundos. El cielo, al mirarlo, pone sosiego en el espíritu. Nada semejante ocurría en el paisaje de la mañana. En él la naturaleza colabora con Cristo; durante la noche las estrellas y la noche armoniosa envuelven a los tres frailes. En la noche todo es pura comunicación. El sentimiento matinal de Sabino era más superficial, hecho de sensaciones; el nocturno de Marcelo es más profundo, hecho de emociones. A Sabino la vista del campo le incitaba a hablar o cantar; a Marcelo le produce un silenco metafísico en el que se llega, mediante la intuición, a las profundidades del ser:

« ¿No veis el silencio que tienen ahora las cosas, y cómo parece que mirándose en este espejo bellísimo, se componen todas ellas y hacen paz entre sí...? ${ }^{47}$.

La comunicación se establece, en el fondo del ser. Además del fervor místico de la noche, los tres personajes ven las cosas maravillándose unas de otras. En la simplicidad más absoluta las cosas se tienden la mano. Ya no hay fronteras y lo humano y lo no humano se percibe como procediendo de un tronco común. Así se nos presenta esta confusión de realidades:

"Y diciendo esto Marcelo, puso los ojos en el agua, que iba sosegada y pura, y relucían en ella como en espejo todas las estrellas y hermosura del cielo, y parecía como otro cielo sembrado de hermosos luceros... ${ }^{48}$.

Es la consumación de aquella identificación de las cosas que hemos comentado. El agua se ha vuelto cielo. La magia del sentimiento y la intuición poética hace que se trastornen las perspectivas. En medio se encuentra el hombre dando alma a esta danza del universo. El silencio de las cosas ha sido tan profundo que han llegado a la misma raíz común de su ser y allí se han visto iguales. El tema del silencio es importante en la estética luisiana. El silencio es necesario para la comunicación de las cosas entre sí y del hombre consigo mismo. Recordemos que para nuestro poeta la felicidad consiste en el conocimiento propio y del universo como paso previo para el conocimiento de Dios. En el orden moral Fray Luis sigue la tradición estoica y en el cosmológico las ideas pitagóricas y platónicas que conciben al hombre como un remedo del macrocosmos, es decir, como un microcosmos. El microcosmos es un reducido pentagrama de la gran sinfonía del universo. Por eso es tan necesario el silencio en la estética lusiana: él es imprescindible para percibir el latido de los seres. El hombre necesita el silencio para hablar consigo mismo. El ruido de las plazas no favorece el conocimiento propio. Ésta es una de las razones de la

46. Ib. 586. ib.

47. Op. cit. 586. Príncipe de la paz.

48. Ib. 599. ib. 
insistencia de Fray Luis en la vida retirada del campo. En todo momento pretendemos mostrar que Fray Luis tiene unas ideas y modos de actuación definidos. No encontramos en él un sistema, pero, si descubrimos la corteza de las palabras, veremos que hay un cauce subterráneo de ideas que es definido y permanente. En esta concepción del hombre en términos de microcosmos y armonía musical está la explicación a la importancia metafísica, estética y ética que Fray Luis da al silencio.

El silencio hace que la identificación con el contorno sea más honda a medida que va cayendo la noche. Ahora nos explicamos mejor la indicación de Sabino de que el paisaje hacía enmudecer a Marcelo. En realidad, lo que Sabino pone de manifiesto es la atención trascendente que Marcelo pone en las cosas. Por tanto, la fascinación ante el paisaje no responde sólo a su carácter melancólico, sino también a la convicción filosófica de que las raíces del ser se ofrecen únicamente a quien mira con atención y espíritu callado el universo. Sucede, al fin y al cabo, algo muy conocido: que las emociones más hondas y comprehensivas no se resuelven en el mundo de la palabra sino del silencio. Los cielos, el agua del Tormes, los tres personajes, todos los elementos participan de la misma corriente del ser. Ha desaparecido la jerarquía que veíamos en la mañana porque en la noche las cosas se nos presentan en su máxima simplicidad. No hay discursión sino intuición que es el medio de aproximación al ser de todos los grandes poetas que en el mundo han sido. La naturaleza y todo el universo luisiano está en una comunicación permanente que envuelve también al hombre arrastrado por el diálogo universal.

\section{La comunicación y el símbolo}

El sentido de la comunicación con la naturaleza está también presente en el episodio de la avecica que ya hemos comentado bajo otro aspecto. Es significativo el comienzo del episodio:

«En la orilla contraria de donde Marcelo y sus compañeros estaban, en un árbol que en ella había, estuvo sentada una avecilla de plumas y de figura particular, casi todo el tiempo que Juliano decía, como oyéndole, y a veces como respondiéndole con su canto; y esto con tanta suavidad y armonía, que Marcelo y los demás habían puesto en ella los ojos y los oídos» ${ }^{49}$.

Tenemos aquí a la naturaleza como un personaje más del diálogo del soto. El sentimiento de comunicación con las cosas se encuentra ahora reforzado por el hecho de que se trata de la naturaleza animada. Los animales se van personificados. Durante el episodio los tres frailes están embebidos en la escena hasta que la avecilla se sumerge en las aguas. Entonces Sabino exclama:

— Oh, la pobre, cómo se ahogó!»

49. On cit. 710. Hijo. 
Esta exclamación nos muestra la identificación con la naturaleza. Es una salida emotiva que nos hace ver la participación del personaje en la desgracia del ave. La simpatía con la naturaleza en su aspecto dramático viene a completar el cuadro luisiano de la comunicación del hombre y las cosas. En la exclamación de Sabino tenemos, primero, el adjetivo "pobre», tan lleno de ternura, y después el dativo de interés «nos» que revela una identificación íntima con el acontecimiento funesto. Sabino continúa inconsolable por la pérdida de la pájara hasta que ésta sale del agua por el lado de Marcelo. Entonces todo es gozo y alegría en la bandada de aves que se alejan y en los personajes de los diálogos:

«Fue grandísimo el regocijo y alegría que de este suceso recibió Sabino. Mas decíame que, mirando en este punto a Marcelo, le vio demudado en el rostro y turbado algo y metido en gran pensamiento, de que mucho se maravilló; y queriéndole preguntar qué sentía, vióle que, levantando al cielo los ojos, como entre los dientes y con un suspiro disimulado, dijo: - Al fin, Jesús es Jesús» ${ }^{50}$.

El misterio de la naturaleza influye sobre Marcelo. Nada se nos dice de la actitud de Marcelo, pero el episodio de la avecica debe de ser el de su propia vida. La naturaleza está continuamente hablando a los interlocutores. En ella encuentran símbolos y actitudes humanas. Este sentimiento de identificación con la naturaleza animada había sido expresado ya admirablemente por los clásicos, especialmente el poeta Virgilio. Es un sentimiento previo a la unión con las cosas inanimadas donde el hombre ha de poner toda su capacidad intuitiva al servicio de las cosas sin vida que le rodean. El dolorido sentir con la naturaleza animada se potencia en el episodio comentado por la simbología personal que tiene y que vincula al hombre a los hechos de la naturaleza. No hay sólo un objetivismo de simpatía con el mundo animal, sino la experiencia subjetiva de que los avatares personales tienen su traducción en el exterior. Basta mirar atentamente la naturaleza para encontrar formas de vida que nos descubren el significado de la nuestra. Diríamos que la naturaleza de Los Nombres no sólo es signo de Cristo sino también y en cierta manera signo del hombre. Es signo de Cristo en el orden religioso y del hombre en el orden ético. Es la convicción de que, por encima de lo aparente, hay algo que acerca a los hombres y al mundo exterior y que nada del uno le es ajeno al otro. La fascinación proviene aquí del descubrimiento de que la vida de la naturaleza tiene direcciones a la vida del hombre.

\section{En resumen:}

Hay en Los Nombres de Cristo un proceso de identificación entre el hombre y la naturaleza. Ya desde el principio aparece el paisaje como una in-

50. Op. cit. 711. Hijo. 
vitación al diálogo. Ante él Sabino quiere cantar y Marcelo siente el ala del misterio.

La comunicación con los elementos exteriores se acentúa al llegar la noche. El paisaje va calando más en los personajes. El soto, sin el horizonte lejano de La Flecha, invita al recogimiento. Allí las estrellas son el gran auditorio de Marcelo.

El silencio de las cosas es un elemento destacado de la estética luisiana. En él el hombre percibe el latido de los seres y se conoce a sí mismo. Su importancia tiene como base la concepción de la armonía del universo y el hombre en términos musicales. En el silencio se comunican y se hermanan las cosas todas.

El episodio de la avecica nos muestra la identificación con la naturaleza animada, y en su carácter simbólico vemos la búsqueda de significados por encima de lo aparencial que el poeta pretende en todo momento.

\section{EL DRAMATISMO DE LA NATURALEZA EN LA EXPOSICIÓN DEL LIBRO DE JOB}

La Exposición del Libro de Job es, a nuestro modo de ver, la obra más existencial y profunda de Fray Luis de León. Su contenido resulta completamente moderno. Así como el Comentario del Cantar de los Cantares respondía a una actitud de plena juventud y agresividad ante la vida, la Exposición del Libro de Job nos muestra una actitud de cansancio y, en muchas ocasiones, de amargura. Al estudiar la obra del Cantar hicimos una breve comparación entre ambas exposiciones. En los dos extremos de la vida del poeta el tema de la naturaleza viene a dejar claras dos posiciones espirituales y dos estéticas diferentes: renacentista la del Cantar, barroca la del Job.

El Comentario del Libro de Job es el esfuerzo de muchos años. Comenzando probablemente en la prisión, hacia 1571 ó 1572, los comentarios se extienden hasta 1591 , poco antes de su muerte. A partir del capítulo 33 deja constancia de la fecha y el lugar de redacción. Firma el 33: Deo gratia-Princii, $\mathrm{VI}^{\circ}$ Novem. An. 1580; el 33 de nuevo en Valladolid el 10 de diciembre del mismo año y el último, el 42, lo termina en Salamanca, el 8 de diciembre de 1591, meses antes de morir.

La rẹdacción de este libro coincide con las situaciones más dramáticas de la vida del poeta, y con sus más elevadas poesías. A la descripción detallista y gozosa del Cantar, a la composición serena y bien pensada de Los Nombres sucede la meditación pausada sobre los más graves problemas humanos. El Comientario del Libro de Job nos muestra al otro Fray Luis, al que aplastaban el civlor y la negra melancolía. Es la confrontación del hombre frente a su pro- 
pio enigma y al del universo. Aquí están magnificados los grandes temas de Fray Luis: el conocimiento de sí mismo, del mundo y de Dios. En el Job se plantea la angustia del hombre que no llega a comprender ni el proceso de los hechos humanos ni el ser del Universo en que vive. El conocimiento se encuentra al final con un paso infranqueable que sólo es dado conocer a Dios. Un estoicismo cristiano ha reemplazado al platonismo. La filosofía platónica, que ha sido el camino del poeta en gran parte de su obra, no sirve para estas situaciones límites. En los comentarios de los capítulos 38 y 39 hay ya un abandono de lo religioso de la búsqueda inquisidora por el universo. La muerte ya cercana le va dejando al poeta solo frente a Dios. Por otra parte ha habido en Fray Luis un proceso constante de espiritualización que coincide con el encuentro con las obras de santa Teresa. De la concepción de la naturaleza del Cantar sólo quedan aquí algunos elementos. La fundamentación existencial y religiosa en la que prevalece al final. El orden y la armonía que el poeta había aprendido en la estética platónica han dejado el lugar a una situación caótica donde se funde la súplica a Dios, la muerte y el desorden de la naturaleza. Son magníficos los tercetos del capítulo 10 del Job en los que Fray Luis pone mucho de sí mismo '.

El tono del Libro de Job simpatizaba con la actitud espiritual de Fray Luis siempre preocupado por la inestabilidad de las cosas y el proceso cambiante del universo. La pérdida continua de ser se traduce aquí en algo más cercano al hombre, en la pérdida continua de vida: ¿Qué lejos estamos del gozo del Cantar!:

«Y a la verdad, todo el vivir nuestro no es sino un continuo perder el ser y el vivir que se tienen; y así nuestra vida, no solamente es un camino apresurado a la muerte, más también una pérdida continua de vida, y es muerte que cada momento hace vigilia a la muerte» ${ }^{2}$.

Esta pérdida de ser es lo que preside la concepción luisiana de la naturaleza en el Job. Las cosas le dicen poco a este peregrino de la realidad total. La idea platónica de lo aparencial que necesita de Dios para permanecer en su

1. Mas pues lo poco de mi vida dura

conoces, ten Señor, la mano airada;

dame un pequeño espacio de holgura,

antes que dé principio a la jornada

para nunca volver; antes que vea

la tierra triste de negror bañada;

la tierra negra, tenebrosa y fea,

de confusión y de desorden llena,

falta de todo el bien que se desea,

adende es noche, cuando más serena.

Fray Luis de LeÓn, Poesías, Edición, introducción y notas del P. Ángel Custodio Vega OSA., Barcelona 1970, págs. 435-436.

2. Op. cit., 868. Job, $4,19$. 
existencia, forma parte integrante de la vida del poeta. Él participa de la defección del ser del Universo: es el intimismo y la comunicación con el entorno vital y cosmológico que hemos comentado en otras ocasiones. También el carácter de Fray Luis influye aquí hasta el límite. La melancolía no es ahora sólo un cambio en la forma de ver el mundo exterior, sino una tragedia interna que agrava su visión pesimista y dolorida. La melancolía viene a magnificar la síntesis de todas las situaciones dolorosas, que Fray Luis centra en lo que él llama el dolor puro: abandono completo de Dios. El poeta percibe el dolor de Job en su plenitud. El desorden que impone el castigo de un inocente, junto a ese dolor puro, está presente en la atención prestada a una naturaleza en su fase más dramática: las tormentas.

\section{La naturaleza atormentada}

Frente a la bucólica del Cantar, la armonía de Los Nombres y la búsqueda peregrina de las poesías, la naturaleza de la Exposición del Libro de Job se caracteriza por su condición de atormentada, lo mismo que el espíritu del poeta. Así se relacionan la idea de comunicación, típica de todo auténtico sentimiento de la naturaleza, y la preferencia por lo terrible, propia del romanticismo. No es la naturaleza epicúrea de Horacio, ni siquiera las bellas tormentas de Virgilio, sino una naturaleza que se revela contra el orden de las cosas y destroza los campos y priva al pobre labrador de su sustento. Es una belleza de líneas rotas frente a la curva grácil de su primer comentario en castellano. El objetivismo distante o estético de Horacio o Virgilio se torna aquí en una comunicación dolorida en la que el hombre se siente asociado existencialmente a los eventos del mundo exterior.

Fray Luis se ha fijado en dos tipos de tormentas tremendamente dramáticas por su espectacularidad y sus desastres: las del mar y las del verano. Son también tema de sus poesías. La primera destruye las naves y los hombres; la segunda destruye los frutos en flor:

«Y dice esto galanamente, por semejanza de lo que suele acontecer, o en la mar cuando se levanta tormenta, o en la tierra con la tempestad que enciende los vientos; y se cierra el cielo con nubes, y rasgan el aire los truenos, y viene un aguacero, y no ha descargado aquél cuando con el mismo estruendo y furia viene otro, y luego otro, con que la tierra se anega, y la mar se embravece y levanta sus olas; las cuales, sucediendo siempre las unas a las otras, miserablemente combaten y rabajan a los navegantes» ${ }^{3}$.

Son las tormentas del mar las que más impresionan al poeta. Asiste, impotente, a la destrucción. Los elementos de la naturaleza en actividad causan tẹrror. Al mito clásico o a la creencia bíblica que veía en las tormentas el poder

3. Op. cit. Pág. 1304, Salmo 41, 7. 
de los dioses, no se le han sustituido con una explicación científica todavía. La razón del siglo XVI se ha desnudado de mitología, pero no ha ofrecido explicaciones convincentes a los fenómenos de la naturaleza. De ahí que el viejo pavor a los dioses sea aquí un miedo ante lo desconocido. La naturaleza se convierte en un poder autóctono que supera a las posibilidades del hombre, y que sale por sus fueros cuando le parece. Viene a incidir en la angustia que sentía Fray Luis de León al desconocer las causas y la constitución de los fenómenos naturales. Su mejor expresión filosófica nos la dejó en la oda a Felipe Ruiz «¿Cuándo será que pueda...?» Al comentar el episodio de la avecica veíamos la relación de semejanza que el poeta percibía entre su vida y el exterior. La base es el sentimiento de unidad de todo lo existente. En el Comentario del Libro de Job se da también ese plano de la comunicación. Lo que nos interesa es ver cómo las comparaciones para ilustrar la condición desgarradora de Job se toman del entorno natural. Existe una afinidad que nos trae el poder de la imagen. Así los dolores se agazapan en la alegría del hombre «y como las tempestades vienen como sin pensar, en verano, porque el verano es tiempo alegre y sereno, y destruyen antes que se sazonen los frutos, y es mal que viene de golpe y presto" ${ }^{4}$. En otro lugar hace una descripción tensa, precisa y acongojante de una tormenta veraniegas.

Ha habido un cambio desde una visión ética u objetiva a otra que penetra en la intrahistoria del hombre. Las tormentas naturales exteriores y las interiores del espíritu se potencian mutuamente. Hay una proyección del alma del poeta hacia el exterior. En el universo las cosas participan unas del destino de las otras.

\section{El enigma del Universo}

En el orden del pensamiento estas tormentas nos revelan la confusión de la mente de Fray Luis respecto al mundo que le rodea. En 1590 y 1591, año de su muerte, el poeta no ha encontrado todavía lą solución al enigma del univer-

4. Op. cit. 1207, 8. Job, 36, 14.

5. «Porque a unos días los hace tristes el ser nublados; a otros tempestuosos con torbellinos; en otros suceden tempestades negras como la noche cerrada, y cerradas, y que son como una sombra de muerte; y los bochornos y las calinas otras veces no sólo turban el cielo, más hacen amargas e incomportable la vida... Porque lo que decíamos amarguras de día, en su original es lo que en español llamamos calinas, cuando en el verano o estío se espesa y escurece el aire con vapores gruesos que, con el calor encendido, se convierten en horno, de manera que respiran los hombres fuego y padecen increible tormento... porque, cuando acontece se pone temeroso todo; y no sólo el semblante del cielo tiene un escuro triste, más también las nubes que le enraman están como teñidas de herrumbre, y el aire se colora de entre pardo y amarillo, y todo lo que por su medio se mira parece también amarillo, y ansí hace horror en una cierta manera».

Op. cit. 847. Job, 3, 4. 
so. Ante esa impotencia lo que ha hecho es pasar el misterio científico y filosófico a lo religioso. Profundamente intelectualista, Fray Luis desea saberlo todo. Francisco Pacheco nos declara las diversas ramas del saber en que era versado. De los tres deseos de conocimiento que tiene, sólo uno le satisface al final de su vida, el de Dios. De aquí el espíritu ardientemente religioso de sus últimos años. Y que sigue preocupado por el enigma del universo lo muestran su comentario a las increpaciones que hace Dios a Job sobre el principio de las cosas. Hay un pasaje que nos revela claramente esta persistencia del enigma al final de la vida de Fray Luis: es el comentario al versillo 4 del capítulo 38 del Job «¿Dónde eras al fundar yo la tierra? Manifiéstalo, si tienes saber». Téngase en cuenta que firma este capítulo en Madrid, el 14 de diciembre de 1590. Comenta el poeta:

«Y ansí todo aqueste discurso es una relación por menudo de las obras naturales que hizo Dios, que el hombre ni entiende comenzando de las más altas y viniendo a las más bajas, y de las generales a las más particulares y propias, arguyendo siempre secretamente que quien no sabe esto que trata y se viene cada día a los ojos, menos entenderá los consejos que tiene cerrados Dios en su pecho»" ${ }^{6}$.

Debía ser grande es desgarrón del espíritu de Fray Luis cuando un año antes de su muerte no había llegado todavía a situar el mundo en que vivía. Sigue admitiendo el sistema ptolomaico a pesar de las ideas de Copérnico que ya para entonces comenzaban a ser realmente conocidas en Salamanca, divulgadas por el agustino Fray Diego de Zúñiga. Siempre está presente el terror ante lo desconocido.

Todas las preguntas cosmológicas que hace Dios a Job están presentadas en términos de maravilla. Nuestro poeta se siente como un niño ante el universo. Así es caso maravillosamente extraño para él que la tierra se sustente en el aire, y lo son la mar y la luz que acorta los días en invierno y aumenta los del verano, y los tesoros de nieve de que habla en la oda a Felipe Ruiz, y los vientos y la lluvia y el movimiento de los astros. Hay aquí una fascinación, pero no la búsqueda filosófica de las poesías. El enraizamiento de la naturaleza en lo religioso es el fin de la concepción luisiana del universo. Llega aquí por dos caminos: el del cansancio e impotencia de una larga especulación platónica y el místico por el que las cosas son un reflejo de Dios. Fray Luis llega a estas convicciones en el Comentario de Job después de haber recorrido el primer camino. De ahí que no exista aquí la superación por la idea mística, tal como se ve en sus poesías y en Los Nombres, sino una actitud de abandono del problema de Dios, lo que supone una decepción filosófica. Hay un párrafo en el que el poeta expresa claramente su propio desgarrón y la situación espiritual en que se encuentra al final de su vida:

«Ansí que es ignorante el hombre, porque es moderno y porque anda ciego

6. Op. cit. - 1233. Job, $38,4$. 
en eso mismo que ve, como parece en lo poco que entiende de la fábrica de la tierra a do mira»?

Es interesante analizar el alcance que en el campo semántico de la luz tiene en Fray Luis. En su momento haremos algún comentario sobre esta estética de raíz platónica, que tiene una significación destacada en nuestro poeta. Otro pasaje nos muestra la misma idea de la cita anterior:

«Ansí que las verdaderas y propias causas de esto natural y visible, no las alcanzan esos mismos que en su estudio se emplean» ${ }^{8}$.

Es decir que Fray Luis ha llegado a una convicción bien triste: la ciencia no puede alcanzar el conocimiento auténtico de las cosas. La ciencia únicamente puede conocer lo aparencial y lo fáctico, pero el ser real queda oculto. Al hombre no sólo se le escapan los secretos de la naturaleza, sino también el ser del tiempo, vinculado al proceso cambiante de las cosas. Fray Luis tiene una preocupación profunda por el tema del tiempo. Es ya pleno barroquismo:

«Pues decir agora Job que los tiempos no se asconden a Dios, es decir que lo que a nosotros se asconde, que es el verdadero tiempo y la vida que sucede a esta vida, no se asconde a Él..." ${ }^{9}$.

\section{La astrología}

Hay en la Exposición del Libro de Job una preocupación astrológica mucho más patente que en laś demás obras. No se trata de un simple juego. Detrás hay toda una concepción del universo como un libro de signos que hay que descifrar. Esta idea viene alimentada por la Cábala, la tradición clásica, la filosofía árabe y el pensamiento cristiano. No existe en el Renacimiento la mitificación de los astros como fuerza de un dios, pero sí la idea de que cada hombre tiene su destino marcado en las estrellas. Sin duda alguna, esto es una visión estética en nuestro poeta. Lo cierto es que, cuando el dolor y la oscuridad mental de los problemas básicos del hombre aparecen, aflora a él esta idea de la vinculación entre el quehacer de los hombres y el rotar de los astros. La simpatía que el poeta tenía por los eventos de la naturaleza y el sentimiento de la unidad del cosmos favorecían estas ideas astrológicas. La perplejidad ante el mal y la justicia lleva a situar el origen de este desorden que un poder exterior a Dios, y nada más fácil que acudir a las estrellas, cuya tradición de eternidad y materia superior persistía. Durante el Renacimiento las creencias astrológicas -en bromas y en veras - están de moda. El mismo Kepler tuvo que ganarse la vida componiendo calendarios astrológicos. Todo enigma supone una humillación intelectual. Ya con el pie en el estribo, cuando el poeta

7. Op. cit. - 1234. Job, 38, 4.

8. Ibid. 1224. Job, 37, 14

9. Ibid. 1076. Job, 24, 1. 
de Salamanca se pone a comentar uno de los capítulos finales del libro más dramáticamente humano de la Biblia, se encuentra roto intelectualmente entre dos actitudes: la religiosa, en que todo está explicado, y la existencial, donde lo fundamental queda sin explicar.

«Y porque por la luz y las tinieblas y las moradas de ambas, se entiende también lo de la muerte y la vida, y juntamente sus causas, que son las constelaciones y aspectos celestes en que la luz y la noche viven y moran, por manar en cierta manera dellas el vivir y el morir, el venir a esta luz común o el salir della, dejándola» ${ }^{10}$.

En esta parte de nuestro trabajo acudimos con frecuencia a la etopeya de Fray Luis, y ello porque el Comentario del Libro de Job es realmente una biografía espiritual. Va nuestra simpatía con esta obra de sentir dolorido y de lenguaje menos retórico y pensado, pero más expresivo y directo que el resto de las obras en prosa. La situación personal del escritor alumbra el contenido de este comentario, y al revés. Escrita durante la segunda mitad de su vida, esta Exposición recoge la versión interior de cuanto acontecía en el exterior. Hay un pesimismo resignado de signo estoico, que nos adelanta el pensamiento de Quevedo y la honda amargura de Cervantes ante los sucesos humanos. Los objetivos dejan paso a una rica interioridad. El colorido es gris.

Con todo, muy de vez en cuando, el poeta nos trae acentos del Cantar llega una ventana abierta de frescura cuando, al describir el amanecer, nos dice que, «la parte del cielo que se viste de luz, se colora con arreboles... y se descubre una veta de luz extendida y enarcada y bermeja, que es como los ojos o las pestañas con que nos comienza a mirar la aurora»" Esto supone un cromatismo nuevo y desconocido, que contrasta con la tonalidad difusa de la obra. También está presente el recuerdo de la I Geórgica de Virgilio en este párrafo inspirado de sabor a naturaleza:

«Porque cuando la sazón del tiempo va inclinando a ser húmeda y cuando llover quiere y antes que llueva, los bueyes sienten luego la mudanza del aire, y lo dan a entender alzando en alto la nariz, y abriéndola y atrayendo el aliento para sí con más fuerza» ${ }^{12}$.

Pero esto es lo menos en esta obra donde prevalecen las largas consideraciones que nos invitan a una reflexión sobre la triste condición del hombre. En un libro de absoluta sinceridad donde las corrientes estéticas renacentistas tienen menos cabida. La personalidad del poeta lo inunda todo con su propia luz. De ahí la modernidad de esta obra. El hombre es siempre el mismo cuando se enfrenta ante los problemas básicos del mal o de Dios. Los enigmas y las dudas son hoy semejantes a las que se planteaba el viejo Homero. Si en algunas ocasiones las páginas del Comentario del Libro de Job nos traen un hondo

\footnotetext{
10. Op. cit. 1238. Job, 38, 20.

11. Op. cit. 1273. Job, $41,9$.

12. Ibid. 1212, Job, 36, 33 .
} 
pesimismo sobre el hombre es porque la vida consciente del pensador es así. Es la impotencia radical para conocer el ser de las cosas sobre su corteza aparencial, porque, como dice Fray Luis «la flor tiene mucho de parecer y muy poco de ser y el hombre así mismo» ${ }^{13}$.

\section{El hombre, la tierra y la plenitud del ser de las cosas}

Hemos visto que la unión que se da entre el hombre y el mundo exterior en el Comentario al Job tiene caracteres barrocos. Se afirma la cercanía del hombre a la tierra en que vive. Aparece la metáfora de la tierra como madre de todo: «Desnudo, dice, naci del vientre de mi madre, que me engendró, y desnudo volveré al vientre de la tierra, que es también nuestra madre» ${ }^{14}$. Aparece la vieja comparación bíblica de la vida como el curso de un río, que también expresó Jorge Manrique, cuyos versos repite Fray Luis. Este fluir de la vida y las cosas es una de sus constantes llamadas, como ya hemos indicado. Las aguas de la tierra y el mar, los vientos y todo lo que se mueve sobre el planeta indican el cambio continuo del ser de las cosas y la pisada sin huellas sobre el mundo. El afán renacentista de pervivencia en la fama que encontramos en la oda a Juan de Grial no tiene lugar en el Comentario al Libro de Job. Junto a la metáfora de la muerte como un sueño del que nunca despertamos, se extiende el de la vida del hombre como el curso de las aguas:

"Que ansí como el agua que viene de la mar por los secretos senos y mineros de la tierra, y se descubre en el nacimiento de los ríos y fuentes, los cuales corren y pasan, o la que hecha vapor se cuaja en nubes, y, vuelta en lluvia, torna a caer y hacer avenidas y arrollos que corren con impetu y se pasan en poco espacio, y el suelo por donde pasaron queda seco después, y no vuelven más a pasar ni dejan de sí más memoria, así el hombre, después de muerto, no vuelve ni se levanta de este duro sueño después que le comienza a dormir. $\mathrm{Y}$ es semejanza usada en las divinas Escrituras y en otras, comparar la vida del hombre ál río, y el discurso de aqueste nuestro vivir a las aguas» ${ }^{15}$.

Fray Luis pospone todo conocimiento de la realidad de la naturaleza a una plenitud del ser de las cosas. Hay aquí una bella interpretación religiosa que confirma la idea luisiana de la unidad del universo y del hombre caminando hacia un mismo fin. La plenitud del ser de las cosas, cuyo conocimiento se ponía en una superior vida de estilo platónico en la especulación filosófica, y en la vida futura en lo religioso, se pospone aquí la resurrección bíblica de los muertos. Entonces el hombre y el mundo adquirirá la plenitud del ser en una configuración y en un estado más perfecto. Interpreta la metáfora de la vida y

13. Op. cit. 977. Job. 14, 2 .

14. Ibid. 832. Job, 1, 22.

15. Op. cit. $980, J o b, 14,12$. 
los ríos como la afirmación de que la realidad auténtica no será posible «mientras durare esta mudanza natural de las cosas que se suceden, corrompiéndose unas y engendrándose otras, y mientras los cielos la forma y movimiento que ahora tienen tuvieren. Porque cosa cierta es en la divina Escritura que cesará todo y que tomará el mundo otra figura y estado mejor, al tiempo que los muertos tornaren a vivir en sus cuerpos» ${ }^{16}$.

El camino religioso ha llevado al poeta a hacer un acto de fe en el hombre y en las cosas, al mismo tiempo que supone un desengaño e insatisfacción del momento actual. Son los dos polos del pensamiento luisiano sobre el mundo exterior que explican tanto sus gozos íntimos ante el espectáculo de la naturaleza y el firmamento como el desgarrón dolorido ante la impotencia intelectual para traspasar el misterio de las cosas.

\section{El descubrimiento de América}

Apuntamos ahora dos noticias curiosas sobre el descubrimiento de América y la empresa y el lema de las obras de Fray Luis.

El poeta da una interpretación escatológica del capítulo 28 del Job y del versillo 23 del comentario latino «In Abdiam prophetam» refiriéndolo al descubrimiento del Nuevo Mundo. Fray Luis, que viajó poco, como él mismo dice ${ }^{17}$, siente la nostalgia de lejanías, y exalta el afán aventurero y caminante del español que, para entonces, había dado ya la vuelta al mundo:

«Y los divide, dice, del pueblo peregrino, esto es, de los españoles, que entre todas las naciones se señalan en peregrinar, navegando muy lejos de sus tierras y casas, tanto que con sus navegaciones rodearon el mundo» ${ }^{18}$.

Fray Luis, marinero en tierra, como le llama el P. Félix García, participa de la nostalgia del mar que tanto atrae a los españoles de la época. En el comentario latino «In Abdiam prophetam» expresa su admiración y su orgullo:

«Ac principio statuere pro certo debemus, quamvis superioris oevi omne, historiam evolvamus, tamen nos reperturos non esse aliquid, quod vel majus sit, vel magis praeter omnem opinionem, et expectationem acciderit, quam id quod patrum nostrorum aetate accidit, cum nobis et hoc Romano non mi-

16. Ibid. 981. Job, 14, 12.

17. «...porque, como es público, y a Vs. Mds. debe constar ya dello, desde el año catorce de mi edad y razón que es dese que tengo entendimiento y razón, soy fraile, y todo el tiempo que hay desde entonces hasta agora, he residido en Sant Agustín de Salamanca, donde tomé el hábito, sin salir del reino, ni hacer ausencia de aquel lugar si no fue el espacio de dos años que en veces diferentes estuve en Sant Augustin de Soria y en Sant Augustin de Alcalá de Henares...» (MIGUEL Salvá y Pedro Sainz de Baranda, Documentos inéditos para la historia de España, Madrid, 1847, vol. X, 257).

18. Op. cit. 1110. Job, 28, 4. 
nor, sed latior fortasse atque major orbis, ab Hispanis, vastissimo navigato mari, repertus est» ${ }^{19}$.

En el comentario del capítulo 28 del Job nos demuestra Fray Luis sus preocupaciones por las cuestiones geográficas y físicas conforme a los conocimientos fel momento. Nos da una visión de tono clásico de la tierra del Nuevo Mundo «adonde el fuego ascondico en las cavernas de ella rompe de improviso y sin pensar y sale fuera en muchos lugares, por los muchos volcanes que en ella hay y se descubren de nuevo» ${ }^{20}$. Nos trae el mito de la Atlántida y el otro de las minas del Potosí que «hasta el año 85 desde el 45 , que son cuarenta años escasos, ha valido su quinto ciento y once millores de pesos de a trece reales cada uno. Por manera que ha dado en este espacio de tiempo quinientos y cincuenta y cinco millones, sin lo que se hurta al registro" ${ }^{21}$. Se ve que la costumbre de burlar al Fisco es muy antigua. Al final nos habla del tema, tan viejo en él, de la armonía en el mundo.

\section{La empresa y el emblema de Fray Luis}

Dentro de la preferencia lusiana por la simbología de la naturaleza ésta le ofrece la empresa y el lema de sus obras. En la empresa en óvalo figura una carrasca con unas ramas desmochadas y otras floreciendo. Hay un hacha apoyada del tronco de la planta árbol. El lema «Ab ipso ferro» está tomada de Horacio. También le dio dolores de cabeza al poeta. Lo explica en el comentario "In Abdiam prophetam» y en el capítulo 8 del Job. La naturaleza ofrece la altanería de su persistencia y de su renacer continuo. Ésta, que en otras ocasiones significa el proceso fluyente de las cosas, simboliza aquí la idea estoica de la constancia y la lucha:

«... que del tronco cortado, o de algún pequeño rastro de raíces dejadas que quedan siempre en lo hondo, tornará a renacer más hermoso y más fresco, de manera que no le podrán deshacer ni la injuria del tiempo ni la violencia del hombre» ${ }^{22}$.

Pero la mejor expresión se encuentra en las aliteraciones crujientes de dos estrofas de la oda a Felipe Ruiz «Del moderado y constante»:

«Bien como la ñ

carrasca en alto risco desmochada

con hacha poderosa,

del ser despedazada

del hierro torna rica y esforzada.

19. Fray LuIS, Ópera, III, pág. 156.

20. Op. cit. 1110 . Job, 28,5 .

21. Ibid. 1111. Job, 28, 10.

22. Ibid. 921. Job, 8, 19. 
Querrás hundilla y crece

mayor de que de primero; y si porfía

la lứcha más florece;

y firme al suelo envía

al que por vencedor ya se tenía» ${ }^{23}$.

\section{En resumen:}

En relación con el tema de nuestro trabajo la Exposición del Libro de Job plantea la angustia del hombre frente a un universo que no conoce. Al renacentismo del Cantar sucede el barroquismo del Job. Nos presenta a la naturaleza en su fase más dramática: las tormentas de verano y las del mar. Ello simpatiza con la situación interior del poeta. Hay una asociación del hombre a los eventos exteriores.

La peregrinación a la búsqueda del ser auténtico de las cosas cede aquí a una solución religiosa que no supone en este caso una arribada feliz, puesto que no proviene de un misticismo superador sino del desengaño ante el fracaso intelectural. De aquí, en gran parte, el pesimismo de la obra.

Vemos también las preocupaciones astrológicas del poeta, explicables en un sistema en que falla la apoyatura intelectual y no hay explicaciones precisas para la supervivencia en el mundo de la injusticia y el mal.

El hombre se siente pegado a la tierra como a la madre de las cosas. Sólo hallarán su plenitud de ser en la resurrección religiosa.

Hacemos dos notas curiosas a la obra: Fray Luis interpreta el capítulo 28 del Job en términos escatológicos como el anuncio del descubrimiento de América por los españoles. La naturaleza le ofrece también el símbolo estoico de una ñudosa carrasca que, habiéndola podado, vuelve siempre a renacer.

\section{Estébanez}

23. Fray Luis de León, Poesías, Edición del P. Vega, pág. 53. 